\title{
Effects of Drought in
}

the Rio Grande Basin

By H. E. THOMAS and others

DROUGHT IN THE SOUTHWEST 1942-56

GEOLOGICAL SURVEY PROFESSIONAL PAPER 372-D

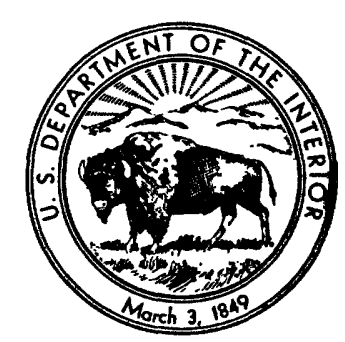

UNITED STATES GOVERNMENT PRINTING OFFICE, WASHINGTON : 1963 


\section{UNITED STATES DEPARTMENT OF THE INTERIOR STEWART L. UDALL, Secretary GEOLOGICAL SURVEY \\ Thomas B. Nolan, Director}

For sale by the Superintendent of Documents, U.S. Government Printing Office Washington 25, D.C. 


\section{CONTENTS}

Abstract

Introduction.

Upper Rio Grande

San Luis Valley, Colo., by T. G. McLaughlin

Middle Valley and tributaries, New Mexico........

Sunshine Valley, by I. J. Winograd.........

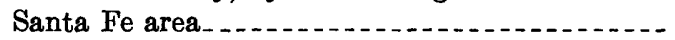

Grants-Bluewater area, by E. D. Gordon.....

Elephant Butte-Fort Quitman area, New Mexico and

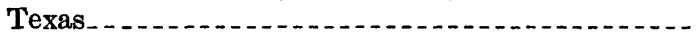

Elephant Butte and Caballo Reservoirs.........

Ground-water reservoirs, by C. S. Conover...-

Problems developed or magnified in drought. . . .

Storage development. . . . . . . .

Unconfined aquifer in San Luis Valley.....

Surface reservoirs.........................

Rincon, Mesilla, and El Paso Valleys.....

Consumptive waste and water salvage..........

Quality of water...........

Recapitulation of assets and liabilities.........

Instruments of management for sustained yield....

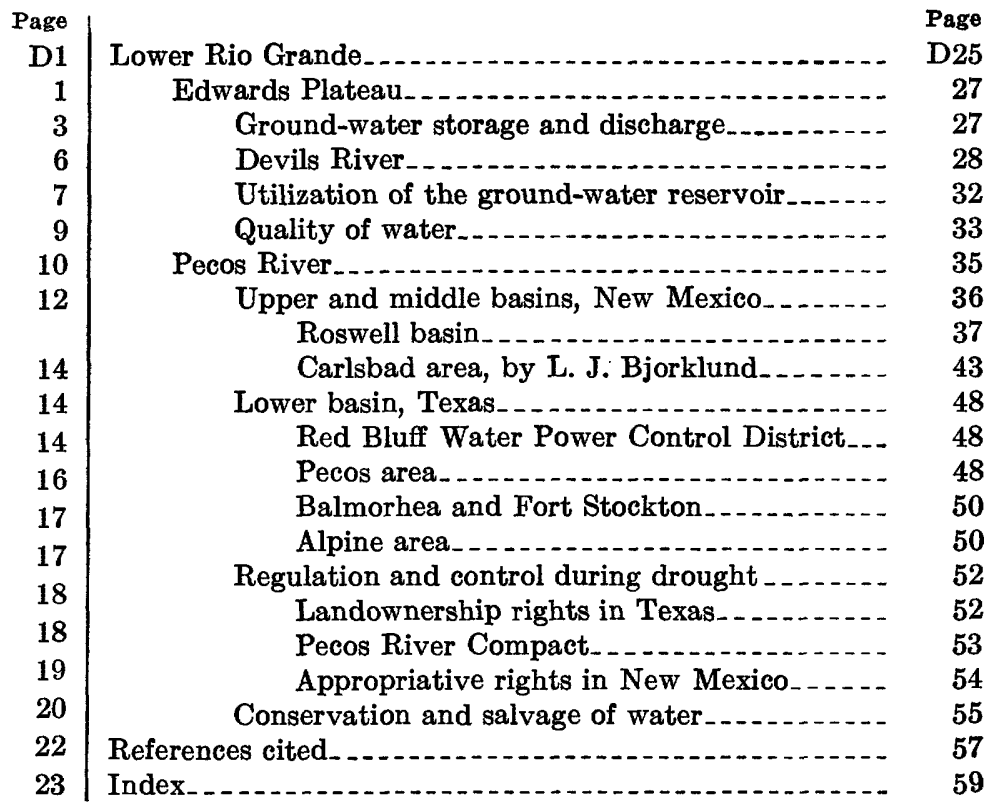

\section{ILLUSTRATIONS}

Figure 1. Index map showing Rio Grande basin

2. Inflow to and outflow from principal divisions of the upper Rio Grande basin, 1895-1957

3. Hydrographs of wells in San Luis Valley, 1948-57

4. Municipal water supply, Santa Fe, N. Mex., 1880-1955

5. Changing patterns of water use in Grants-Bluewater area, 1926

6. Inflow to Elephant Butte Reservoir, 1916-58

7. Hydrograph showing average depth to water in 39 wells in Mesilla Valley, 1946-58

8. Quality of water in the upper Rio Grande, 1933-57

9. Runoff of the lower Rio Grande, 1901-58

10. Hydrographs for Devils River and Goodenough Springs, and water level in well near Del Rio, Tex., 1927-56.---

11. Relation of Devils River runoff to precipitation in drainage basin, 1901-58

12. Discharge of Devils River from current and antecedent precipitation, 1927-56

13. Dissolved load in the lower Rio Grande, 1934-58.

14. Concentration of soluble salts in the lower Rio Grande, 1934 58

15. Suspended-sediment load of the lower Rio Grande, 1934-54

16. Measured runoff and calculated depletion, Pecos River between Alamogordo and Red Bluff Reservoirs.......

17. Cumulative mass diagram of precipitation compared with runoff in middle basin of Pecos River, 1905-56....-

18. Ground-water reservoirs of Roswell basin showing trends in recharge, discharge, and storage, 1935-55........

19. Some effects of depletion of the ground-water reservoir in Roswell basin .

20. Water supply for the Carlsbad project, 1915 58

21. Discharge from Capitan limestone near Carlsbad, 1939-58

22. Fluctuations of quantity and quality of water in Red Bluff Reservoir, 1937-58

23. Discharge of springs near Toyahville and Fort Stockton, Tex., 1931-58_.

24. Increase of saltcedar area, Pecos River basin, 1937-53. 

DROUGHT IN THE SOUTHWEST, 1942-56

\title{
EFFECTS OF DROUGHT IN THE RIO GRANDE BASIN
}

\author{
By H. E. Thomas and Others
}

\section{ABSTRACT}

In headwater areas of the Rio Grande and its principal tributaries, variations in streamflow and in ground-water storage and discharge depend upon fluctuations in precipitation, with modiflcations by geologic factors and by the pattern of water development and use. In downstream areas the surfaceand ground-water resources are replenished not only by local precipitation but also by outflow from the headwaters areas; thus the effects of drought upon those water resources are complex and may be vague and indeterminate.

\section{INTRODUCTION}

The Rio Grande basin is one of five areas of the Southwest subdivided for detailed discussion of the effects of drought as distinguished from other water shortages. The Rio Grande (or Río Bravo in Mexico) is an interstate and international stream. It rises in Colorado and flows southward for more than 400 miles across New Mexico, then forms the boundary between Texas and the United States of Mexico for about 1,200 miles to its mouth (fig. 1). The Rio Grande has a total length of more than 1,800 miles and is the second longest river in the United States; its drainage basin encompasses about 182,000 square miles. ${ }^{1}$

Hydrologically the Rio Grande includes an upper river above Fort Quitman, Tex. (about 90 miles downstream from El Paso), which is generated entirely within the United States and almost entirely used up in Colorado and New Mexico, and a lower river that is regenerated chiefly by flow from Mexico.

The upper Rio Grande has a drainage area of about 35,000 square miles, less than a fifth of the waterproducing area of the Rio Grande basin. According to the report of the Rio Grande Joint Investigation (National Resources Committee, 1938), the total mean annual water production from runoff in the period

1 Water producing area only. The outer rim of the Rio Grande basin encompasses 335,000 square miles, including closed basins between the Pecos and Rio Grande (Thomas and others, 1962b) in the United States, and extensive closed basins bordering the drainage areas of the Río Conchos, Río Salado, and Río San Juan in Mexico.
1890-1935 was about 3 million acre-feet, of which more than half was used consumptively for irrigation in New Mexico and Colorado. The river is generally lowest in average annual flow in the barren reach below Fort Quitman. In the 20 years $1924-43$ the average discharge from the upper basin at Fort Quitman was about 200,000 acre-feet.

According to records of the International Boundary and Water Commission (1943), the Rio Grande at the gaging station below Presidio, Tex., with drainage area of about 60,000 square miles, had an average annual discharge of 1.4 million acre-feet in 1924-43, chiefly from the tributary Río Conchos in Mexico. In the same period the average annual measured runoff of the Rio Grande was 3.5 million acre-feet at Laredo, Tex. (drainage basin 133,000 square miles), and 5.1 million at Rio Grande City (drainage basin 174,000 square miles). These figures, as well as those for the upper Rio Grande, are averages based on records for years prior to the beginning of the most recent drought.

The Pecos River, with a drainage basin greater than 38,000 square miles, joins the Rio Grande below the mouth of the Conchos, and is the largest tributary entering the lower Rio Grande from the United States. Like the Rio Grande, the Pecos has headwaters in the Rocky Mountains, its water is used extensively in New Mexico, and the outflow from New Mexico is considerably less than the flow in the river farther upstream. However, the Pecos gains much water as it flows across the Edwards Plateau region in Texas, and as it enters the Rio Grande it has a larger volume than at any other point along its course.

The principal use of water throughout the Rio Grande basin is for irrigation, and the total area irrigated within the basin is estimated (International Boundary and Water Commission, 1950) to have been about $2,700,000$ acres in 1950 . Of this total about 950,000 acres is in the upper basin above Fort Quit- 


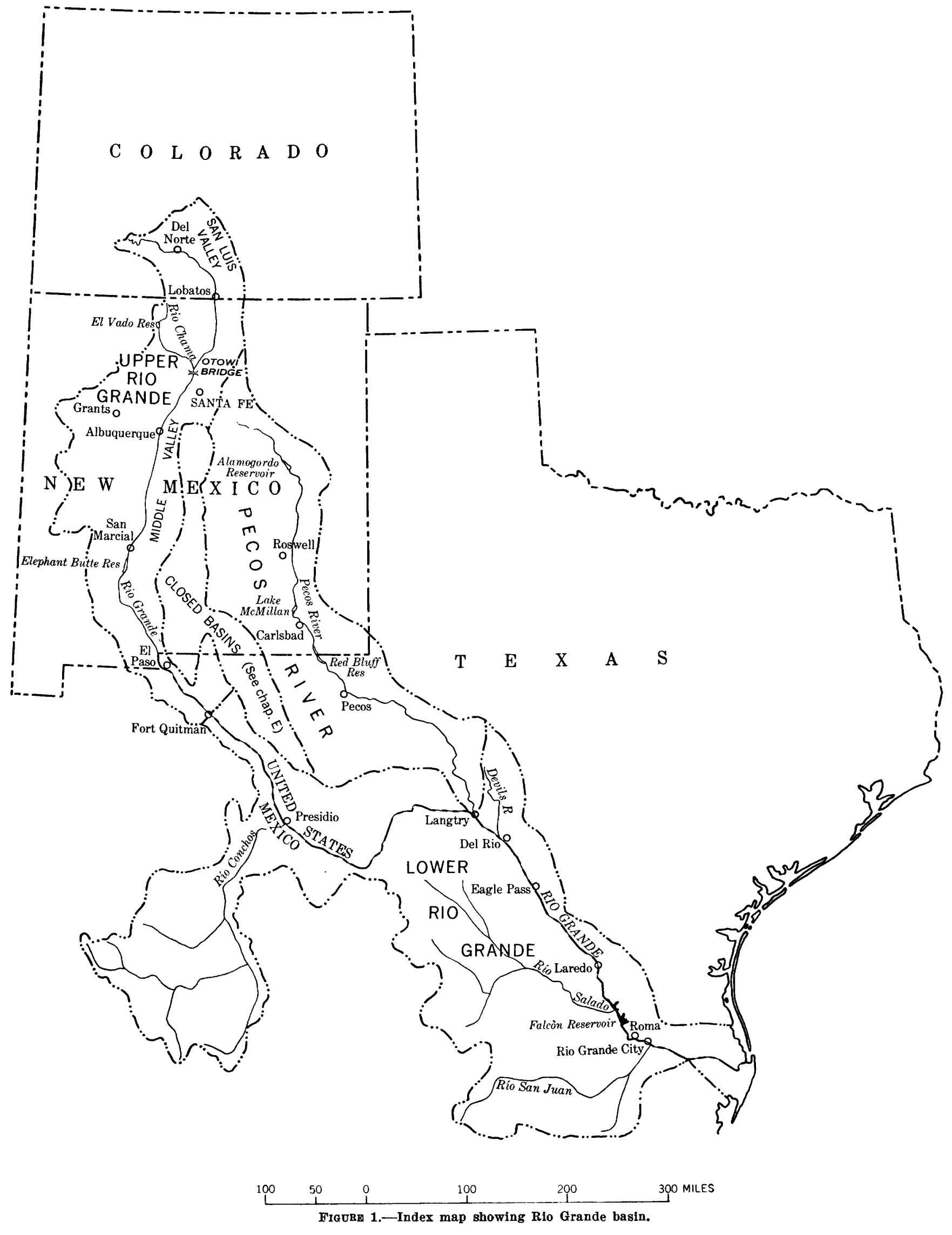


man, and about the same acreage is served by major tributaries in the lower basin (Pecos River, 240,000 acres; Río Conchos, 200,000; Río Salado, 125,000; and Río San Juan, 330,000 acres). The remaining 800,000 acres is along the main stem below Fort Quitman, including about 700,000 acres in the lower Rio Grande valley below Rio Grande City.

\section{UPPER RIO GRANDE}

The headwaters of the Rio Grande are in the rugged San Juan Mountains and Sangre de Cristo Mountains of Southern Colorado. In both ranges there are several peaks that exceed 14,000 feet in altitude, and areas where the mean annual precipitation exceeds 40 inches. In the agricultural valleys along the Rio Grande, however, the average annual precipitation is only 7 to 10 inches, and this is true even in San Luis Valley near the headwaters, where the valley floor ranges from 7,500 to 8,000 feet about sea level. Because of this meager precipitation, irrigation has been prerequisite to successful agriculture along the upper Rio Grande, presumably from the earliest days of habitation. The Spanish explorers in 1540 found that in the many-storied towns of the Pueblo Indiansof which 17 or 18 are still in existence-water was diverted from the river in acequias, or irrigation ditches (Follett, 1898), of which several are still in use. Thus irrigation has been practiced continuously along the upper Rio Grande longer than in any other part of the United States: at least 400 years of recorded history, and probably for several centuries before that.

In comparison to the rest of the Southwest, the upper Rio Grande also has a longer history of water shortages and disputes, and of treaties and decrees and compacts to settle disputes. The town of Albuquerque was founded in 1706, and by 1739 some residents had moved several miles to the south, partly because of shortage of water for the fields at Albuquerque. A water shortage in the early 1890's developed international repercussions because it affected people in Mexico as well as in Texas and southern New Mexico. The shortage was attributed chiefly to the increasing development and use of water for irrigation in San Luis Valley in the preceding decade, but it is to be noted that it coincided with a period of deficiency in precipitation (p. D4). This water shortage was responsible for the "embargo" of 1896 and for the Rio Grande Convention of 1906 between the United States of America and the United States of Mexico. The "embargo" was an order by the Secretary of the Interior which prevented further irrigation development of any magnitude in the Rio Grande basin in Colorado and New Mexico by suspending rights-of-way across public lands for use of Rio Grande water; the "embargo" was not lifted until 1925. Under the terms of the Treaty of 1906, the United States guaranteed an annual delivery in perpetuity of 60,000 acre-feet of water in the Rio Grande at the head of the Mexican Canal near El Paso, Tex.

In 1929 the States of Colorado, New Mexico, and Texas ratified a temporary compact which provided in effect that neither Colorado nor New Mexico would cause or permit the water supply in the Rio Grande to be impaired by new or increased diversions or storage unless and until such depletion was offset by increase of drainage return; this compact was operative until October 1937. In 1938 the same States ratified the Rio Grande Interstate Compact (Witmer, 1956, p. 154-177), which provides for apportionment of the water of the upper Rio Grande basin on the basis of specified indexes of flow at key gaging stations (p. D23-24).

In keeping with the long-continued concern over the water of the upper Rio Grande, long records of streamflow are available for many places along the main stem and its principal tributaries; at Embudo, N. Mex., north of Santa Fe, the U.S. Geological Survey initiated its stream-gaging program in 1889. However, most of the available records concerning other aspects of hydrology are shorter and less complete, and the data concerning ground water are especially meager.

The report of the comprehensive Rio Grande Joint Investigation (National Resources Committee, 1938), which provided the basic data essential for the negotiation of the Rio Grande Compact of 1938, is of great value in studying the effects of drought upon the basin's water resources. Although that investigation was completed several years before the beginning of the most recent drought, it covered a period (18901935) that began in drought and ended in drought. Because of the intervening wetter years, it was concluded in that report that the median natural streamflow during the period of record was close to the median flow for a much longer period.

In all parts of the basin the natural streamflow has been modified by man to such an extent that there are few places where it can be computed reliably from existing records. Many modifications had been underway long before the beginning of these records, but many others occurred during the period 1890-1935 and have been noted in the report of the Rio Grande Joint Investigation. Such modifications include changes in diversions, reservoir storage, irrigated acreage, and drainage of surface water; changes in groundwater storage; and changes in cover of vegetation that 
is dependent upon ground water. In some places the effects of these modifications by man have reached a sort of equilibrium in subsequent years, perhaps different from natural conditions but nevertheless fairly stable. In other places they tend to reflect or even to enhance the natural fluctuations in supply from precipitation (p. D17).

In accordance with natural divisions, the upper Rio Grande basin comprises three principal areas: the San Luis Valley in Colorado, the Middle Valley in New Mexico, and the Elephant Butte-Fort Quitman area in New Mexico, Texas, and Mexico. The Rio Grande enters San Luis Valley near Del Norte, Colo., where streamflow records have been collected at a gaging station since 1889 . From these and other streamflow records the total annual production of runoff has been calculated (National Resources Committee, 1938, p. 28-37, 175-183), and is shown in figure $2 A$. This graph indicates natural fluctuations with least modification by man. The total inflow was less than the long-term mean in 10 of the 13 years 1892-1904, the first drought recorded in streamflow records, and was greater than the mean in 17 of the 25 years in the following wet period, 1905-29. The drought of $1930-40$ resulted in less than average inflow in 7 of the 11 years. After a short wet period, $1941-45$, there were several more years of less than average inflow to San Luis Valley, but these were interspersed with years of more abundant streamflow. In the headwater area the 1892-1904 drought was more severe than any subsequent drought, because it included the least annual runoff and the longest succession of consecutive years of low flow (Gatewood and others, 1962). The Rio Grande headwaters are along the margin of the area of 1942-56 drought (Thomas, 1962), and also in a meteorologic region where annual variations in runoff are not as great as in many parts of the Southwest; as shown by Gatewood and others (1963), the standard deviation for Rio Grande at Del Norte is about 240,000 acre-feet. In 62 years of record, the runoff was below the mean for not more than 2 consecutive years, except in 2 periods of 4 consecutive years (1899-1902 and 1953$56)$.

The runoff of Rio Grande near Lobatos, Colo., represents the residual flow below San Luis Valley. There was a gradual increase in average annual streamflow depletion (ruled pattern in fig. 2) from about 600,000 acre-feet in the 1890 's to more than 800,000 acre-feet in the 1920 's, during which time the irrigated area increased from 250,000 to 550,000 acres.

Figure $2 B$ shows the flow of Rio Grande into the Middle Valley as measured at Otowi Bridge near
San Ildefonso, N. Mex., the total inflow to the Middle Valley as estimated in the Rio Grande Joint Investigation, the measured residual outflow at San Marcial, and the streamflow depletion within the Middle Valley. Here it was found (National Resources Committee, 1938, p. 37-47) that there had been relatively little change in stream depletion from 1890 to 1935 , except that due to variation in water supply; there is an apparent downward trend, in both inflow and outflow in the past 50 years. The hydrographs for the Middle Valley show also the effects of longterm climatic fluctuations, including the drought of 1892-1904 (interrupted by a wet 1897) and a wetter quarter of a century beginning in 1905. The drought of the 1930's was not so pronounced as in San Luis Valley, but the drought beginning in 1943 was more so.

Figure $2 C$ shows the inflow to Elephant Butte Reservoir (or flow through the reservoir site prior to 1915) and the diversions and other releases from the reservoir; figure $2 D$ shows the yearend reservoir storage. The inflow reflects major climatic fluctuations even though modified by the developments upstream. The outflow has been small and fairly constant since the construction of Elephant Butte Reservoir except in 1942 when there was spill from the reservoir. In all these graphs there is a general downward trend since 1920 , interrupted in the wet years 1941-42.

Figure 2 shows the effects not only of climatic fluctuations but also of human adaptation to them. Once the irrigated acreage had become stabilized, the consumptive use tended to be more nearly constant from year to year than the natural runoff resulting from precipitation. Although the stream diversions were necessarily less in dry years than in wet years, the proportion of the total runoff diverted in a dry year was generally greater. Thus the fluctuations in the annual outflow from San Luis Valley, if expressed in percentage of the long-term average, would be more pronounced than the fluctuations in inflow to that valley. There was even more extreme fluctuation in the outflow from Middle Valley, which constitutes the inflow to Elephant Butte Reservoir. By contrast, the small outflow measured at Fort Quitman results from practically complete consumption of water within the upper Rio Grande basin.

A description of the effects of drought upon the upper Rio Grande is difficult because of the problems of segregating the local effects in specific areas, and integrating those effects upon the resource as it moves downstream; and also the problems of discriminating the effects of recurrent drought from the effects of development and control. For this task we have relatively incomplete basic hydrologic data. The pat- 


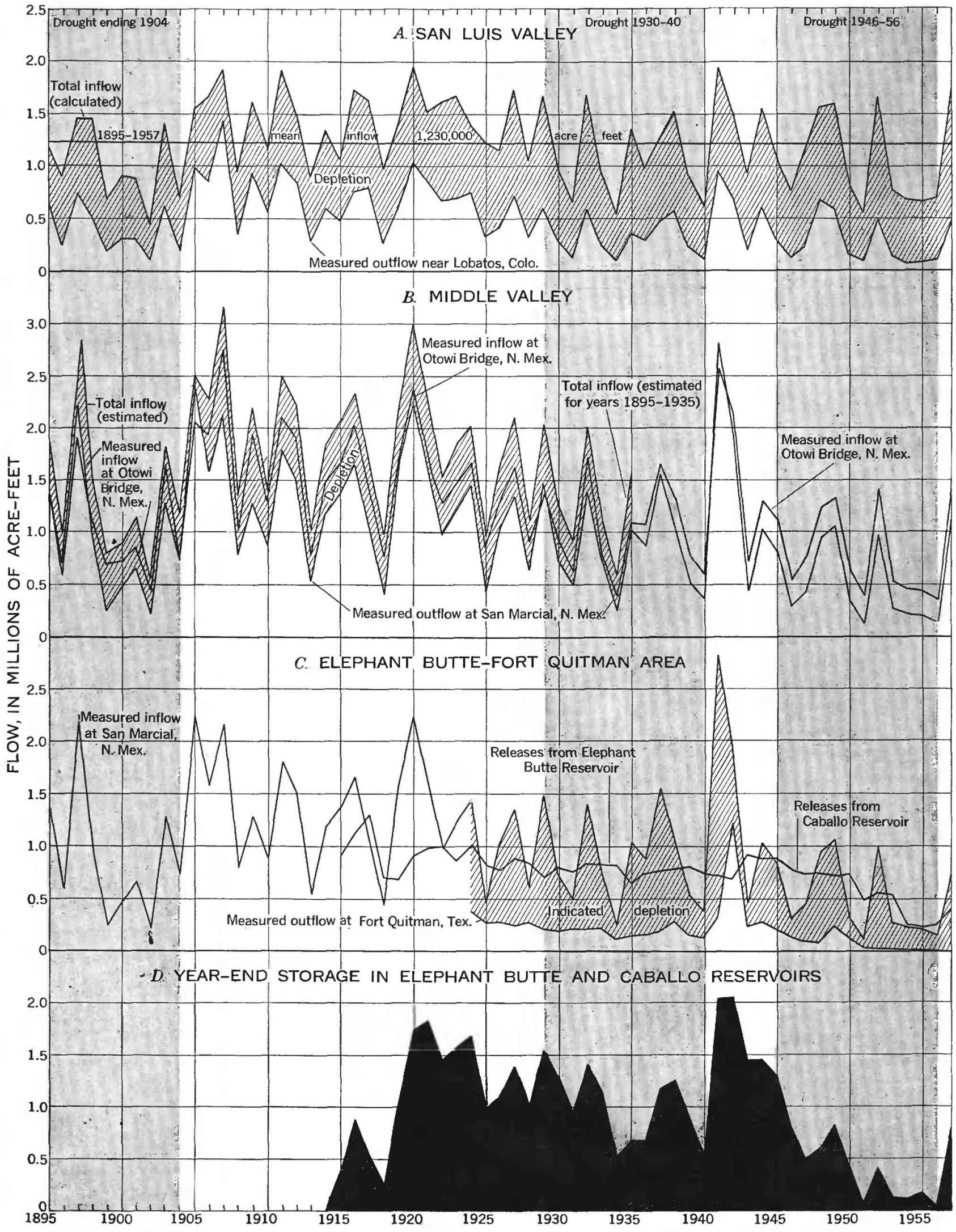

FIGURE 2.-Inflow to and outflow from principal divisions of the upper Rio Grande basin, 1895-1957. 
tern of the discussion that follows is therefore dictated in part by the availability of those data: first, a summary of the water resource and its development in each of several areas where we have information concerning the ground water as well as the surface water; then a discussion of several regional problems that have been developed or magnified during the recent Southwest drought.

\section{SAN LUIS VALLEY, COLORADO}

By T. G. MCLAUghLIN

San Luis Valley is a plain about 90 miles long from north to south and 50 miles wide, and thus is nearly as large as the State of Connecticut. Although this plain is 7,500 to 8,000 feet about sea level, it is properly termed a valley because it is bordered on three sides by mountains that are 10,000 to more than 14,000 feet above sea level. The Rio Grande and other streams have had no part in forming the valley, which is a structural trough between two prongs of the Southern Rocky Mountains-the San Juan Mountains to the west and the Sangre de Cristo Mountains to the east. The Rio Grande continues southward from San Luis Valley all the way to the Mexican border, in a continuation of this same structural depression. Although the Rio Grande and other streams have not formed the San Luis depression, they have gone far toward filling it, and are primarily responsible for the establishment of the present broad valley floor. The deposition of sediment by the Rio Grande in comparatively recent geologic time has formed a topographic divide in the northeastern part of San Luis Valley and has created a closed basin having a drainage area of 2,940 square miles. Because of this natural condition, several tributaries of San Luis Valley are not tributary to the Rio Grande and make no contribution to the river; indeed, the contribution is in the opposite direction, for the Rio Grande loses some water to the closed basin.

Several major physiographic provinces - the Basin and Range, Colorado Plateaus, Rocky Mountains, and Great Plains provinces, which farther north span the entire breadth of Nevada, Utah, and Colorado-all converge in the vicinity of San Luis Valley (National Resources Committee, 1938, p. 198). In such a focal point of geologic activity, it might be expected that San Luis Valley would be like no other in the United States. True, San Luis Valley is quite spectacular in its present setting of rugged mountains, but if the alluvial sediments that underlie the valley floor could be removed, the result would be a gigantic trough almost 3 miles deep, with its bottom below sea level. The total volume of unconsolidated sediments in the valley is unknown-in fact, the total thickness is not known at any point; however, in a recent oil test the drill penetrated more than 5,200 feet of sand, gravel, and clay before it struck a thick section of volcanic rocks, beneath which was more sand, gravel, and clay. The well was bottomed in gravel at a depth of 8,023 feet. On the basis of this well $\log$ it was estimated that ground-water storage in San Luis Valley is of the order of a billion acre-feet, which is more than the total estimated water production of the upper Rio Grande in three centuries.

As in many other arid basins of the Southwest, the layers of clay in the fill of San Luis Valley serve as confining beds and create artesian pressure in the underlying beds of sand and gravel. One well drilled to a depth of 1,000 feet crossed more than 50 separate flows of water. As estimated by Powell (1958) there are probably 7,500 flowing wells in the valley; in addition, scores of artesian wells are equipped with large pumps. The flowing and pumped artesian wells have a potential yield of about 500,000 acre-feet a year, but many are shut in during part of the year, and the actual yield is not known. Most of the artesian wells are used for irrigation and it is believed that they supply water for the complete or supplemental irrigation of about 150,000 acres. The flow of some wells has diminished over the years, perhaps as a result of deterioration or local interference or overdevelopment. In general the artesian aquifers are regarded as not fully developed.

San Luis Valley also has a shallow unconfined aquifer which is far better than the artesian aquifers as a recorder of the effects of climatic fluctuations and of man's development of the water resources. This unconfined aquifer receives water from the artesian aquifers, both by upward leakage and by downward percolation of water drawn from artesian wells for irrigation. It receives water also by deep percolation of precipitation and especially of surface water applied for irrigation. Water is discharged from the shallow aquifer by irrigation wells, by canals and drains, and by evapotranspiration.

Most of the present shallow aquifer was not saturated until the beginning of large-scale diversions of surface water for irrigation. The history of irrigation in the past 80 years includes (1) irrigation in the central lowlands, with resulting rise of water table until extensive areas became waterlogged; (2) westward migration of farming to the present areas, where, with sufficient surface water and the necessary supply and drain ditches, it is possible to maintain the water table within a few feet of the ground surface for 
subirrigation ("subbing") of crops; and (3) development of pumped wells in the shallow aquifer, especially in years when surface water was insufficient to maintain the "sub." As of 1951 it is estimated that 1,400 to 1,500 irrigation wells pumped on the order of 500,000 acre-feet of water from the shallow aquifer.

In a 291-square-mile area that includes about half the shallow irrigation wells, it was found (Powell, 1958) that the shallow aquifer had an average saturated thickness of 60 feet, a specific yield of 30 percent, and storage of about 3 million acre-feet of water. In a 4-year inflow-outflow study by Mutz (in Powell, 1958, p. 120-129) the consumptive use of water within the area ranged from 307,000 acre-feet in 1949 to 200,000 acre-feet in 1951. The quantities of water diverted from streams and pumped from wells are shown by bar graphs in figure $3 B$. The effects of these additions to and subtractions from the reservoir are shown in the water levels in three wells within the study area, and similar effects may be presumed in years when no data are available as to diversions or pumpage. Thus, after wet 1941, subirrigation was moderately effective until the extremely dry year 1951. With record precipitation in 1952 the water table rose again to "subbing" level and was high also in 1953. From 1954 through 1956 the water table failed to rise to the "subbing" level and in early 1957 it was at a record low level. With abundant runoff in 1957 and 1958, the water table was again high enough for "subbing" by June 1958.

Increases in ground-water storage such as that recorded in 1952 are responsible for part of the difference between stream inflow to and outflow from San Luis Valley (fig. 2). The average annual depletion of Rio Grande within the valley in the 18 years 1936-53 was 800,000 acre-feet, the same as was computed for the years 1927-35, but it ranged from about 500,000 acre-feet in the dry years 1940 and 1951 to a million acre-feet or more in 1941,1949 , and 1952. If 800,000 acre-feet represents the quantity of water that must be taken from the Rio Grande in order to sustain San Luis Valley requirements, then surface water could not fulfill the demand in 1940, 1946, 1951 or 1953 , because total surface-water inflow to the valley was less than 800,000 acre-feet. The difference in recent years has been made up by pumping from wells-which, however, has reduced the storage in the ground-water reservoir. In subsequent wet years this ground-water storage was replenished, and the stream depletion in such years exceeded the consumptive use of water by irrigated crops and miscellaneous nonbeneficial water uses.

\section{MIDDLE VALLEY AND TRIBUTARIES, NEW MEXICO}

The middle section of the upper Rio Grande extends from Lobatos, Colo., near the New Mexico State line, to San Marcial at the head of Elephant Butte Reservoir, a distance of about 270 miles. The northern half of this section is flanked by the southern extensions of the Conejos Range and Sangre de Cristo Mountains, which border San Luis Valley. Throughout most of this reach the Rio Grande flows in canyons or narrow valleys. It is from this part of the drainage area that Rio Grande receives most of its water supply that originates in New Mexico, and most of the water that is used in New Mexico. The principal tributaries are the Rio Chama from the west and several streams rising in the Sangre de Cristos to the east; winter snows on the higher mountains are an important source of the water in these streams. The annual runoff of the Rio Grande at Otowi Bridge near San Ildefonso, N. Mex., downstream from this producing area, is at least double and in most years is 4 or 5 times as great as the quantity leaving San Luis Valley near Lobatos, Colo.

At a point due west of the city of Santa $\mathrm{Fe}$ the Rio Grande emerges from White Rock Canyon and flows southward in a valley that continues all the way to San Marcial, a distance of 150 miles. This is commonly called the Middle Valley; the valley floor is generally 1 to 5 miles wide and is bordered by scarps rising to "mesas" (alluvial fans) that rise hundreds of feet above the valley floor. Most of these lands are within the Middle Rio Grande Conservancy District, which operates El Vado Reservoir (capacity 200,000 acre-feet) on the Rio Chama. The mountain ranges bordering the valley are low and receive precipitation chiefly in summer cloudbursts; the tributaries to the Middle Valley therefore are subject to flash floods that produce relatively small total runoff. There is only meager information concerning the tributary inflow and ground-water inflow from the sides of the Middle Valley. The report of the Rio Grande Joint Investigation (National Resources Committee, 1938, p. 13) gives the following summary of findings based on available data prior to 1936 :

Accurate determination of past stream-flow depletion in the Middle Valley is not possible because of the lack of adequate records of tributary inflow and uncertainty with respect to it. An approximation has been derived, based on such data as are available, in order to furnish a reasonable basis for analyses of the effect upon the Elephant Butte-Fort Quitman section of present and given future conditions of irrigation developinent in the San Luis and Middle sections. The mean annual stream-flow depletion, 1890-1935, Otowi Bridge to San Marcial, is estimated to have been 586,000 acre-feet. The corresponding mean annual tributary inflow derived as a resid- 


$$
\text { Iilinent }
$$


ual in the method of estimating depletion is 359,000 acre-feet. Corrected for present development in San Luis Valley, the derived values for mean annual Middle Valley depletion and San Marcial flow are 580,000 and 1,030,000 acre-feet, respectively ***. Return flow in the Conservancy District, as indicated by the total measured discharge of interior drains in 1936 , was 28 percent of the gross diversions. Data were not available on net diversions ***. The sources of ground water in the Middle Valley are underflow from the mesas on either side and seepage from the river, canals, and irrigated lands. In most areas, seepage from irrigated lands is the principal source, and the water in interior drains is largely derived therefrom. On the other hand, the river is, without doubt, the source of most of the water in the riverside drains. Meager data indicate a total annual underflow from the mesas of between 50,000 and 100,000 acre-feet.

Streamflow records since 1935 have provided a basis for extending several of the graphs of figure 2, which for the years before 1935 are based on data from the Rio Grande Joint Investigation. But the available data are insufficient for accurate calculation of the annual inflow to the Middle Valley, which would be desirable for evaluating the effects of drought. One important element in the hydrologic equation is ground water, and concerning it there is very little information. Conover (1956, p. 12) has summarized the ground-water situation and need for additional data in the following statement:

In contrast to areas where water essentially is being mined, there are certain areas in the State, particularly along the Rio Grande in places such as the Rincon and Mesilla valleys, where ground-water reservoirs are or can be replenished from surface-water supplies.

In such areas efficient utilization of the ground-water resource revolves around the long-term availability of surface water taking into account the need of downstream users, the capture of water being wasted by native vegetation, and maintenance of soil-moisture salinity at a safe level.

In other words, in such stream valleys the total water supply must be considered as a unit, ground water plus surface water. Full integration of the ground-water and surfacewater use in stream valleys apparently could increase measurably the amount of water dependably available for beneficial use.

The ground-water reservoir in the Rio Grande valley is very large when compared with present surface reservoirs constructed in the state.

For instance, in the middle Rio Grande valley, it is estimated that nearly half a million acre-feet of ground water is stored within 100 feet of the surface under each area of valley floor equivalent to a township ( 36 square miles). In other words, there is more water stored under five townships than can be stored in Elephant Butte reservoir.

Underground storage generally has the advantage of being relatively immune to direct evaporation losses, a major item in surface reservoirs in this dry country. Because of the large underground storage, utilization of the ground as a regulating reservoir would result in a firmer supply, during droughts, than could be obtained through manmade surface reservoirs alone.
Full utilization of the ground-water reservoir in the Rio Grande valley would result in an appreciable lowering of water levels during droughts. This would have a threefold effect: (1) Waste of water by water-loving plants would be measurably reduced, resulting in an effective increase in water supply; (2) the quality of the ground water would deteriorate temporarily, owing to cessation of drain flow; and (3) nearly all water users would of necessity use ground water to secure a dependable water supply.

One problem peculiar to the Middle Valley is the ground-water development during the recent drought years in several tributary areas. Some of this development, which doubtlessly was spurred by deficiencies in precipitation, runoff, or spring flow during the drought, provided water for new irrigated areas or industrial uses. Recent studies in the following areas have been concerned chiefly with the water resources in the immediate vicinity of the development, but there has also been some consideration of the effect of pumping from wells upon the flow of the Rio Grande in the Middle Valley.

\section{SUNSHINE VALLEY}

By I. J. WINOGRAD

Southward from the Colorado-New Mexico State line the Rio Grande trough (p. D6) is filled partly by basalt lava from volcanoes within the trough, and partly by alluvium derived from the Sangre de Cristo Mountains. The lava forms a plateau occupying the western two-thirds of the trough, and is interbedded with the alluvium in most of the eastern third. The alluvium forms a piedmont alluvial plain 7,400 to 7,800 feet above sea level, which extends from the basalt eastward 6 or 8 miles to the base of the Sangre de Cristos. The part of this piedmont that extends from Costilla Creek southward for about 20 miles is called Sunshine Valley. The Rio Grande avoids Sunshine Valley by flowing in a canyon that passes west of two of the extinct volcanoes (Ute and Guadalupe Mountains) but elsewhere the Rio Grande is generally within a mile of the edge of the valley alluvium.

Several irrigation wells were drilled in Sunshine Valley in 1947. These wells were so successful that by 1955 there were 44 wells which pumped about 3,500 acre-feet of water for irrigation. Although the Rio Grande does not traverse Sunshine Valley, numerous springs rise along its channel just west of the valley. The possible effect of this ground-water development upon inflow to the Rio Grande was therefore an important objective of a recent study (Winograd, 1959). This study included only that part of the piedmont plain in New Mexico, although some irrigation wells are also in the northward extension of the plain in Colorado. 
The flow in the Rio Grande and its tributary Red River is known on the basis of records from gaging stations to increase in the reach opposite Sunshine Valley. From these and other data it is estimated that the average ground-water accretion between Ute Mountain and the south end of Sunshine Valley is about 80,000 acre-feet annually, of which about 20,000 comes from the ground-water reservoir underlying Sunshine Valley.

The irrigation wells in Sunshine Valley all obtain water from sand and gravel beds in the alluvium, and yield 600 to $3,000 \mathrm{gpm}$. Many wells have penetrated more than 400 feet of alluvial materials, but near the western border of the piedmont plain the alluvium thins to less than 50 feet near its contact with the basalt. As much as 100 feet of fine-grained lake beds intervene between the basalt and the alluvium in the west-central part of the valley. The basalt is far more permeable than the average alluvium penetrated by irrigation wells, but to date it has not been tapped by wells.

The natural pattern of ground-water circulation in Sunshine Valley (Winograd, 1959, p. 30-34) involves (1) recharge by percolation into the alluvium of water from streams, irrigation ditches, irrigated lands, and direct precipitation, amounting to an estimated 20,000 acre-feet in an average year; (2) westward movement within the moderately permeable alluvium under unconfined conditions; (3) also downward movement into the basalt, in many places through intervening less permeable lake beds so that the water in the alluvium is semiperched with respect to the basalt; (4) westward movement in the exceedingly permeable fractures and interflow zones in the basalt; and (5) discharge into the Rio Grande, whose canyon is cut below the level of saturation in the basalt on both sides of the river.

It is concluded that pumping of ground water in Sunshine Valley, on the lava-capped plateau, or in Colorado to the north eventually will reduce the inflow to the Rio Grande by an amount equal to the consumptive use of the water. Owing to the large permeability of the lavas the effect of pumping should rapidly affect accretion to the river unless some wells pump from parts of the alluvium where the underlying lake beds are virtually impermeable-in which case pumping would be from storage for a while and the effect upon the river would be delayed. During the 1955 irrigation season, total pumpage for irrigation in Sunshine Valley (not considering return seepage of the water pumped) is estimated to have been equivalent to 15 or 20 percent of the accretion to the river derived from the ground-water reservoir beneath the valley.

\section{SANTA FE AREA}

The Santa Fe area as described by Spiegel and Baldwin (1962) is the area upon which the city of Santa $\mathrm{Fe}$ and environs depend for water supply, and is also a representative sample of the water-producing area of northern New Mexico. This area is in the eastern part of the Rio Grande trough, and ranges in altitude from 6,000 feet in the southwestern part to 12,400 feet in the Sangre de Cristo Mountains which forms its eastern border. The mountains, which are forested, comprise the eastern fifth of the area, and piedmont plains (grasslands) the remaining fourfifths.

The Santa Fe area has a long history of water use, for the springs and cienagas (areas of spring discharge, locally spelled "cienega") were in use by Indians in 1598 when Spaniards first explored the area. The Spanish had wells for domestic use in 1716 , and were using stream water for irrigation in the mid-1700's. Spiegel found a linear relation between precipitation and the logarithm of the altitudethe precipitation increased from an annual average of 13 inches at 6,000 feet to 45 inches at 12,000 feet; this relation is especially observable in winter. The surface runoff from this precipitation averages 0.5 inch (4 percent of the precipitation) in the piedmont plains and 5.8 inches (23 percent of the precipitation) in the mountains. Long-term average yield is therefore 12,000 acre-feet from 24 square miles of mountains and 10,000 acre-feet from 107 square miles of plains. Of this total yield the average contribution to the Rio Grande would be of the order of 10,000 acre-feet under natural conditions. The Santa Fe River, which drains about 60 percent of the Santa Fe area, under natural conditions has an average annual discharge of about 6,800 acre-feet, and the flow is well sustained because its basin includes a comparatively large area above 10,000 feet where snowpack and glacial sediments store large quantities of water.

By 1880 the uncontrolled flow of the Santa Fe River had become inadequate for Santa Fe's needs, and since that time the increasing population has required progressively increasing development and use of storage, as indicated in figure 4. Total surfacereservoir capacity since 1947 has been 4,100 acre-feet, which is only slightly greater than the current annual municipal water requirement.

The unconsolidated sand and gravel of the Santa $\mathrm{Fe}$ group of Tertiary age forms a productive groundwater reservoir underneath Santa Fe. Three municipal wells were drilled in 1946 and four others by 1950 , but these have been used only in years of inadequate surface supplies. Several irrigation wells 

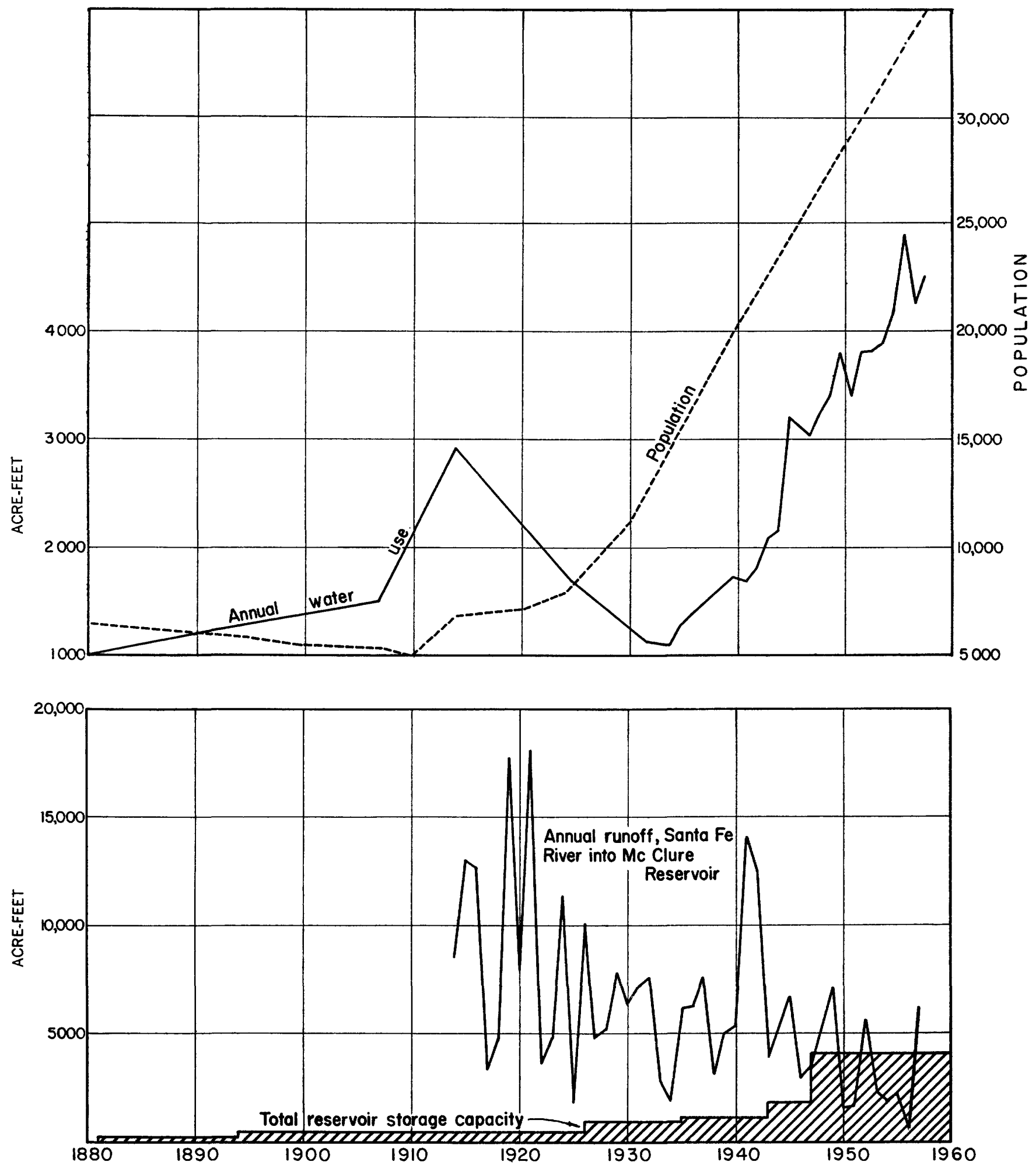

Frourm 4.-Municipal water supply, Santa Fe., N. Mex., 1880-1955. The water supply is under strain to meet demands of increasing population with decreasing streamflow during drought. 
also have been drilled since 1947, and in 1952 there were 10 large-capacity wells in the Santa Fe area, of which 4 were pumped for 6 to 8 months for irrigation and another was used throughout the year. Pumpage from these wells was of the order of 4,600 acre-feet. According to Spiegel (Spiegel and Baldwin, 1962)-

*** As the runoff of the Santa Fe River in wet years is in excess of that which can be stored in the reservoirs (about 4,000 acre-feet) and used; therefore, there are occasional periods of spill. The average annual supply available above Santa Fe, under present conditions of storage and use, is about 5,600 acre-feet. For periods as long as 6 years, the average annual discharge of the Santa Fe River has been less than the sum of current use and reservoir losses. The surface discharge of the Santa Fe River must be supplemented by ground-water supplies in many dry years, and if the demand increases as much as 15 percent in the future, supplemental supplies of ground water will be required in most years. Water-level and pumpage data for the city well field suggest appreciable mutual interference by existing wells, amplified by boundary effects. Excessive declines of water level in the easternmost wells in 1 year of pumping are due to boundary effects and to overpumping of individual wells. The surplus surface flow of water of good quality in wet years could be used to replenish the ground-water supplies withdrawn in dry years by (1) regulating the overflow from the reservoirs so as to allow natural infiltration into the bed of the Santa Fe River where the stream crosses relatively permeable sediments, (2) spreading the water on the broad terraces adjacent to the stream in this reach, or (3) direct injection into wells. The installed capacity of existing irrigation wells and city supply wells in and near the city of Santa Fe already exceeds the annual average recharge and groundwater inflow, but actual average withdrawal will probably remain below the inflow and recharge for many years to come.

\section{GRANTS-BLUEWATER AREA}

By E. D. Gordon

The Rio Puerco drains about 20 percent of the upper Rio Grande basin but contributes only about 5 percent of the water to the Rio Grande above Elephant Butte. This meager contribution is chiefly stormflow, and the Rio Puerco is ordinarily responsible for more than half the sediment that is carried into Elephant Butte Reservoir. Thus the Rio Puerco is of rather minor and dubious value to the Rio Grande system.

The Grants-Bluewater area is a headwater area in the Rio Puerco basin. Bluewater Creek rises on the northeastern flank of the Zuni Mountains and trends generally northeastward and eastward to join the Rio San Jose north of the village of Bluewater. The Rio San Jose, usually dry above the city of Grants, trends generally southeastward to join the Rio Puerco. Bluewater Lake, with capacity of 46,000 acre-feet, is formed by Bluewater Dam which was constructed in 1927. Uranium deposits of major economic value have been located and are being mined in the region northwest to east of Grants, and the area in recent years has been increasing its use of water for industrial and municipal purposes.

Various hydrologic records for the region, presented graphically in figure 5, indicate the following: (1) precipitation was less than the long-term mean in 17 of the 20 years 1937-56-that is, in all years except 1940,1941 , and $1949 ;(2)$ in the 8 years $1937-44$, in spite of this prevailing precipitation deficiency, the quantity of water available from Bluewater Lake for irrigation exceeded 7,000 acre-feet in each year except 1940 , doubtless in part because of holdover storage from 1935-36 and 1940-41 when precipitation was greater than normal; (3) after 1945, water from the reservoir was used for irrigation only in 1948, 1949, and 1952, whereas in all other years the flow past the gage served chiefly to recharge ground water; (4) pumping of ground water began in 1945, and the combined use of ground water plus surface water has exceeded 10,000 acre-feet in each of the 11 years $1947-57$; $(5)$ the irrigated area fluctuated from 2,000 to 4,300 acres in years before 1945 , according to the availability of water from Bluewater Lake, and ranged from 4,500 to 6,000 acres in $1946-55$ when wells provided a more stable supply; (6) beginning in 1955 there has been increasing use of water for industrial and municipal purposes, but this has been balanced by decrease in irrigation use upon a decreasing area. The major changes have thus been (1) from surface water to ground water as the primary source, at least during drought, which provided not only increased stability of supply but some increase in supply; and, more recently (2), an increase in municipal use but no overall increase in use.

The development of ground water has included withdrawal of a considerable quantity from storage. The principal aquifer tapped by irrigation wells is the San Andres limestone of Permian age, which is also a major aquifer in the Pecos River basin (p. D50). In the Grants-Bluewater area the San Andres limestone and the immediately underlying Glorieta sandstone, formerly considered a part of the San Andres, constitute a single aquifer 250 to 300 feet thick having a gentle northeastward dip. Recharge to the aquifer comes from precipitation upon the outcrop area and upon alluvium or basalt where they overlie the aquifer, and from seepage of water from Bluewater Creek, Bluewater Lake, irrigation canals, and irrigated lands. Water is discharged naturally from the aquifer by springs and by evapotranspiration in swampy areas south of Grants. The first successful irrigation well in the area was completed in August 1944, and by 1954 a total of 23 irrigation wells, 3 industrial wells, and 4 municipal wells were in use in the area. Since 

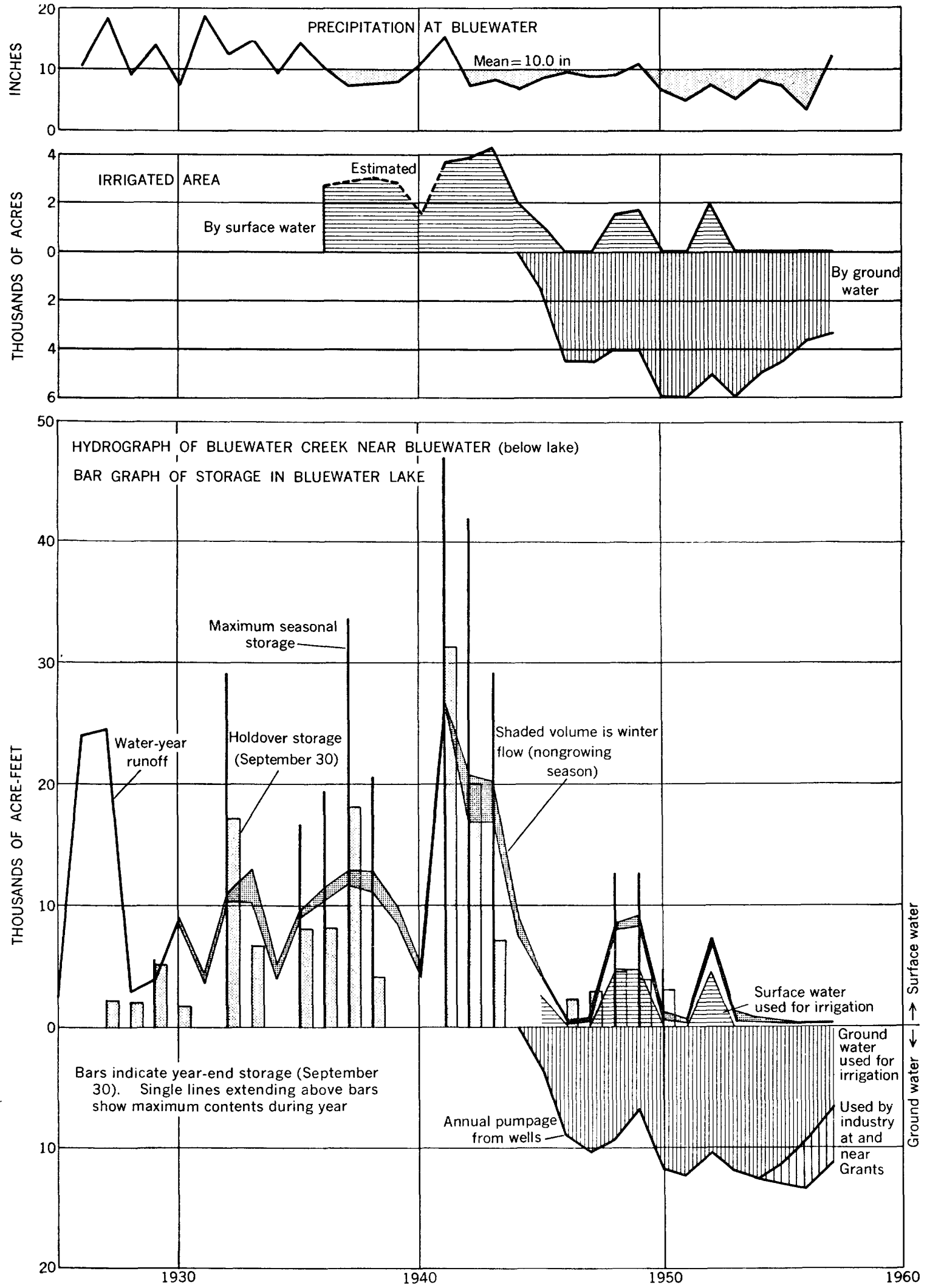

Frgure 5.-Changing pattern of water use in Grants-Bluewater area, from dependence chiefly upon surface storage (1926-44) to dependence upon wells (drought of 1945-57). 
1946, the first year of record, ground-water levels have declined 40 to 45 feet under the area north of the town of Bluewater, whereas the decline has been only about 18 to 20 feet under the irrigated area from Bluewater southeastward to Grants. In the upper part of the area where surface water was available for irrigation in 1948, 1949, and 1952, recharge derived from leakage of canals and of the channel of Bluewater Creek temporarily retarded or reversed the downward trend in water levels.

Since the entire history of ground-water use in the Grants-Bluewater area coincides with the Southwest drought, it is difficult to draw conclusions as to the extent to which the present development can be sustained by the average climate.

Pumping is a new discharge imposed upon a previously more or less stable ground-water system, and water levels are expected to decline as long as largescale pumping continues or until the depletion of storage in the San Andres limestone causes a corresponding reduction in natural discharge by springs and evapotranspiration. It is probable that in some years enough water will be available in Bluewater Lake to provide an adequate amount of surface water for irrigation in the area, in which case the groundwater reservoir will be replenished to some extent. Also, in those years having an adequate supply of surface water, ground-water pumping will be reduced if additional lands are not brought under irrigation. When storage is replenished by surface water, it will be at the expense of flow in one of the tributaries of the Rio Grande. It is doubtful that such depletion will have significant effect upon Rio Grande flow, however, because of the numerous opportunities for evapotranspiration in reaches of the Rio San Jose and Rio Puerco.

\section{ELEPHANT BUTTE-FORT QUITMAN AREA, NEW MEXICO AND TEXAS}

The Elephant Butte-Fort Quitman area extends along the Rio Grande from San Marcial, N. Mex., to Fort Quitman, Tex., a distance of about 250 miles. In the upper 65 miles, between San Marcial and Caballo Narrows, the flanking hills are close to the river; Elephant Butte Reservoir occupies the upper 40 miles, and Caballo Dam forms a smaller reservoir in the lower part of this reach. Below Caballo Dam the river enters Rincon Valley, 30 miles long and as much as 2 miles wide, and then traverses a short canyon before entering Mesilla Valley, which extends southward 55 miles and has a maximum width of 5 miles. About 4 miles above $\mathrm{El}$ Paso the Rio Grande flows through "The Pass" and enters El Paso Valley, which extends about 95 miles to Fort Quitman. Since
1925 the irrigated area in the Elephant Butte-Fort Quitman section has ranged from about 160,000 to 225,000 acres, of which 130,000 to 180,000 is within the United States. In 1946 the irrigated land in the Rio Grande project of the U.S. Bureau of Reclamation (which does not include the lower 55 miles of the El Paso Valley) was 157,000 acres, of which about 17,000 was in Rincon Valley, 84,000 in Mesilla Valley, and 56,000 in El Paso Valley.

\section{ELEPHANT BUTTE AND CABALLO RESER VOIRS}

When Elephant Butte Dam was completed in 1915, the reservoir had a usable capacity of $2,635,000$ acrefeet, but deposition of sediment had reduced this to 2,185,000 acre-feet by 1951. Additional storage and regulation of the river is provided by Caballo Reservoir, completed in 1938 with a capacity of 346,000 acrefeet. The annual inflow has exceeded reservoir capacity only in 1920 and 1941, and the reservoirs thus afford almost complete regulation of the river. Figure $2 D$ shows the storage in both reservoirs at the end of each calendar year, and thus depicts the quantity of water that is held over in each year for use in the subsequent year. These reservoirs stabilized the supply for downstream users during the alternating drier and wetter years of the droughts of the 1930's and 1940 's, when they furnished a fairly consistent supply of 650,000 to 900,000 acre-feet annually. However, beginning in 1951 the reservoirs served only a small part of the needs of the Rio Grande project. A graph of cumulative inflow to Elephant Butte Reservoir (fig. 6) shows the effects of alternating wetter and drier periods, with steeper trend during the wet periods 1919-24 and 1941-42 than in the dry periods 1925-40 and 1943-56, and with a lesser rate of inflow during the most recent drought than in earlier drought periods. The rate of sediment accumulation, as shown by reservoir surveys at intervals of 5 to 10 years since 1916 , is not clearly related to the observed fluctuations in climate and inflows of water. Instead the sediment accumulation has been at a progressively reducing rate since the reservoir was placed in operation.

\section{GROUND-WATER RESERVOIRS}

By C. S. Conover

In 1946, when the inflow to Elephant Butte Reservoir was less than in any previous year except 1934, only 11 wells were pumped for irrigation in Mesilla and Rincon Valleys. In 1947, which was almost as dry, the number of irrigation wells increased to more than 50. With continued deficiencies of surface water the ground-water development increased, until by 1955 there were an estimated 1,600 irrigation wells in 


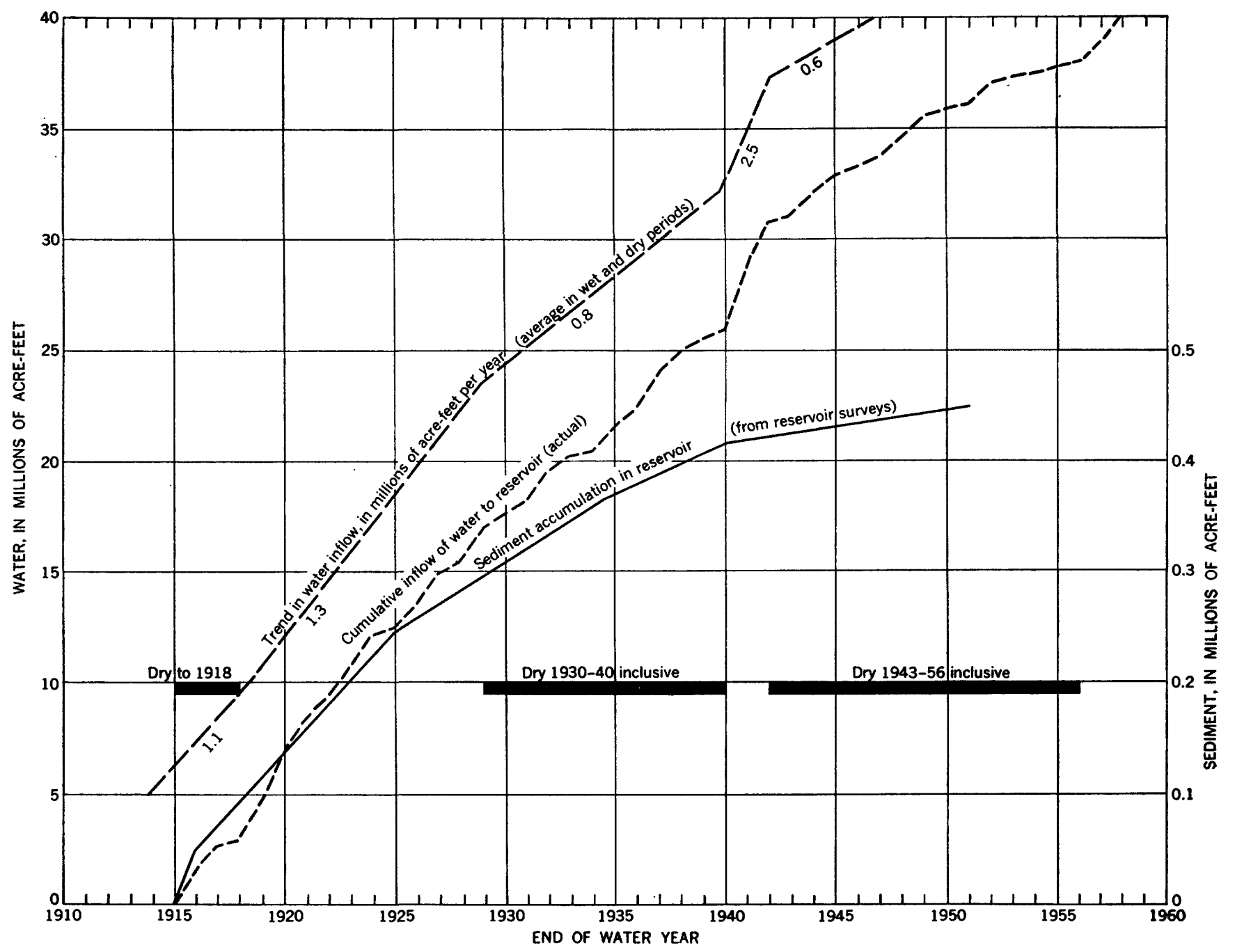

Figure 6.-Cumulative inflow of water and accumulation of sediment in Elephant Butte Reservoir, $1916-58$.

Mesilla and Rincon Valleys, of which 1,200 were used for irrigation of about 96,000 acres of Rio Grande project lands.

A detailed investigation of the ground-water reservoirs of Rincon and Mesilla Valley (Conover, 1954) showed that most wells obtain water from alluvial sand and gravel beds underlying the flood plain to depths of 60 to 100 feet in Rincon Valley, and as much as 200 feet in Mesilla Valley. The ground water in this alluvium is very closely related to the river: it is recharged chiefly from the river, either directly from the channel or from canals and ditches or from river water applied to the land for irrigation; and it is discharged either by evapotranspiration within the valleys or by flow of drains to the river, which in years of normal irrigation supply may include about 250,000 acre-feet discharge through the extensive system of drainage ditches in both valleys. Thus it is concluded (Conover, 1954, p. 2) that "ground water obtained by pumping in the Rincon and Mesilla Valleys does not represent an additional supply or new source of water to the project, but rather a change in method, time, and place of diversion of the supplies already available."

Monthly measurements of water level have been made for a number of years by the Bureau of Reclamation in a network of shallow wells in Mesilla Valley. The hydrograph of average depth to water below land surface since 1946 in 39 of the wells (fig. 7) shows that before 1951 the water table rose to within 6 or 7 feet of the land surface from April to September each year as a result of irrigation from canals, and then dropped a foot or two during the winter. In 1951, however, with a shortage of supplies from Elephant Butte, there was no appreciable rise of the water table during the irrigation season. In 1952 and 1953 the water table was lowered by pumping in the early part of the irrigation season, and then rose 


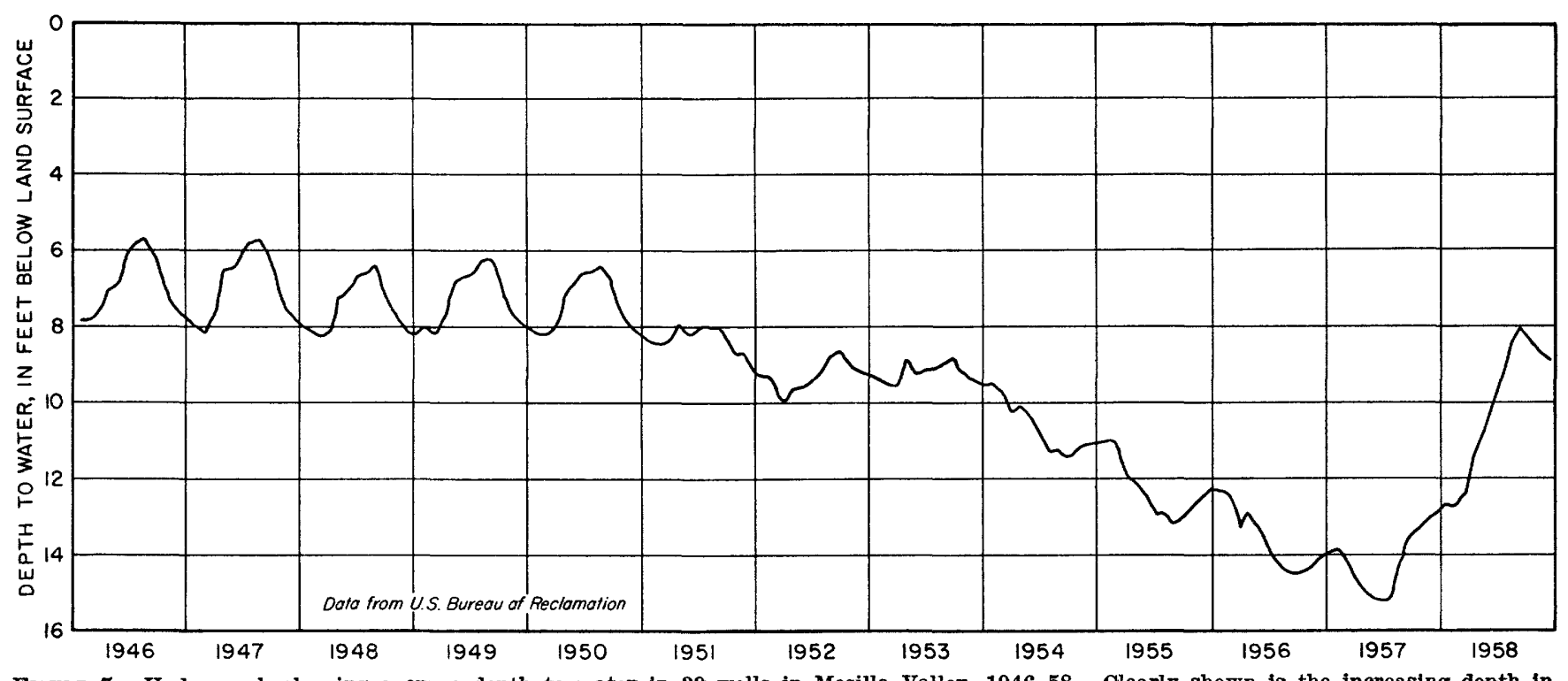

Figure 7.-Hydrograph showing average depth to water in 39 wells in Mesilla Valley, 1946-58. Clearly shown is the increasing depth in drought years 1951-57 and the rapid rise following the end of drought.

in August and September when some surface water was available. Wells were the chief source of water for irrigation in the valley in the four succeeding years, and the water table declined each summer during pumping. By the end of 1956 the average water level in the 39 wells was 6 feet lower than it had been at the year ends 1946 to 1950, inclusive. Rincon Valley had a similar history from 1946 to 1955, according to observations in half a dozen wells. The change in cyclic character of the water-level fluctuations, from summer "highs" to summer "lows," was in response to the change from dependence upon surface water to dependence primarily upon ground water in both valleys. With increased reservoir storage and distribution of water in late 1957 and in 1958, the average water level rose 7 feet from its minimum in mid1957 to a maximum during the summer of 1958 . Thus with the end of the drought came a rapid recovery of ground-water storage and a return to summer "highs."

In El Paso Valley (Smith, 1956) about 500 irrigation wells yielded 120,000 acre-feet of water for irrigation of approximately 45,000 acres in 1954; also, 10 large wells were used to produce water for public and industrial supply. This pumping reduced the storage in the ground-water reservoir in El Paso Valley. Water levels were lowered in all 19 observation wells distributed over the valley; in 10 wells the decline exceeded 3 feet, and in 1 well the water level was lowered $81 / 2$ feet during the calendar year 1954 . In the lower part of El Paso Valley, below the Rio Grande project lands and where surface water was particularly deficient, water levels are reported to have declined nearly 20 feet in some areas during the period 1950-55.

\section{PROBLEMS DEVELOPED OR MAGNIFIED IN DROUGHT}

Throughout the upper Rio Grande basin, each drought has given rise to analysis of water problems, to questions concerning the adequacy of the natural resources to meet the developed needs for water, and to action intended to achieve better balance between supply and demand in the future. The drought of 1892-1904 brought forth the "embargo" of 1896, the treaty of 1906 with Mexico, and plans for the construction of Elephant Butte Reservoir. The drought of 1930-40 spurred the comprehensive Rio Grande Joint Investigation and the subsequent Rio Grande Compact of 1938 between Colorado, New Mexico, and Texas. The most recent drought has been largely responsible for increased utilization of ground-water storage, and has led to further analysis of several problems confronting individual localities and the basin as a whole.

Storage is a major problem because storage of water is a prime requisite for effective use of the highly varying quantities yielded by precipitation. Here we are stressing the storage that can provide fairly constant quantities for use throughout series of wet and dry years, and not concerning ourselves with seasonal storage such as would be required for irrigation in August by water from snow melted in May.

Even if adequate storage capacity is available, there may still be complex problems concerning the conveyance of that water to the reservoirs or other points of distribution. Some water may be "lost" to groundwater reservoirs along the route, and if that loss is determined quantitatively it can perhaps be charged to the users of the recharged reservoirs. There may 
also be losses from the river because of water that is consumed by riparian vegetation, which does not benefit anyone and is therefore wasted. This consumptive waste is a natural phenomenon, of course, and it is greater in amount during wet years than drought years; but it receives especial attention in drought because of the deficiency of supplies available to water users.

The quality of the water in the upper Rio Grande basin has generally been poorer in years of drought than in years of more abundant water supply. Inasmuch as there is, at any particular time, a progressive increase in total salt concentration of the river water from the upper to the lower limit of the basin, it is evident that the problem of quality is more critical to the downstream users than to those near the headwaters.

Finally, apportionment of water may be more important and also more difficult during drought when supplies are less than normal. Apportionment is a prime objective of international treaties, interstate compacts, State laws, and court decisions pertaining to water. Current problems of storage development, water salvage, water quality, and apportionment are summarized in the following sections.

\section{STORAGE DEVELOPMENT}

It is perhaps trite to remark that history is generally written from a human viewpoint. Histories purportedly concerned primarily with water are characteristically anthropocentric: they tell when man came, when he saw it, and when he conquered it; and generally give for each storage facility details as to when he saw the need, raised the money, constructed it, dedicated it, and began to use it.

A history written from the viewpoint of the watera sort of "hydrocentric" viewpoint-would in most places not differ from the traditional history. But in the upper Rio Grande basin there would be some marked differences. From the viewpoint of the water, the chronologic order of development of major storage facilities was (1) San Luis Valley; (2) surface reservoirs; and (3) Mesilla, Rincon, and El Paso Valleys. This is the sequence used in the following discussion.

\section{UNCONFINED AQUIFER IN SAN LUIS VALLEY}

It is not possible to give proper credit for the development of the largest reservoir in the upper Rio Grande basin, for there is no place to put a cornerstone, and no name to engrave thereon-no man to claim it as a scientific or political achievement, no government agency to embrace it as an essential ele- ment in optimum utilization of the water resource. At this late date, almost 80 years after the initial development by man, it appears that the reservoir was created chiefly by unenlightened self-interest.

On the basis of the estimate by Powell (1958, p. 89) that it contains about 3 million acre-feet under 20 percent of the valley area, the unconfined aquifer in San Luis Valley must store water equivalent to several times the capacity of Elephant Butte Reservoir. And, although some of this storage was natural accumulation from precipitation and from leakage of artesian aquifers, most of it is artificial in the sense that it resulted from diversions from the Rio Grande. Depletion of the river flow was inevitable during the filling of this ground-water reservoir, but this did not cause much protest from downstream water users until the effects of artificial depletion were combined with the effects upon natural streamflow of the drought beginning in 1892.

The unconfined aquifer of San Luis Valley is an offstream reservoir: water stored in it moves away from the river and toward a closed basin which is a major area of natural discharge. The closed basin includes the 1,700 square miles of San Luis Valley which is separated by a low divide of alluvial materials from the part of the valley tributary to the Rio Grande. The lowest part of this closed basin is close to the foot of the Sangre de Cristo Mountains on the east side of the valley, and is clearly defined by a succession of alkali flats and by a chain of lakes of which San Luis Lake is the largest. The water table in the closed basin in 1936 had the form of a closed depression, with water moving toward a low point somewhat south of San Luis Lake. The depth to ground water under 90 percent of the valley floor did not exceed 8 feet, and under 70 percent it was less than 5 feet.

The quantities diverted from the river to the closed basin do not reappear in the river at some future date, and thus San Luis Valley has not served as a stabilizer of river flow. Instead, the San Luis Valley's economy, requiring fairly constant amounts of water in wet and dry years, has aggravated the problem of providing a stable supply for use downstream. For example, the inflow to San Luis Valley in 1946 was about half as great as in 1944, but the outflow was less than onefifth as large. The water supplies for the Middle Valley are far more variable from year to year than are those for San Luis Valley, partly because of this artificial increase in the amplitude of fluctuations in Rio Grande runoff; and also, as shown by Gatewood and others (1963) because there is greater variation in the natural runoff of tributaries entering the river 
below San Luis Valley. Typically the natural and artificial fluctuations coincide to make wet years wetter and dry years drier in the Middle Valley than in San Luis Valley. Thus in the wet year 1941 the calculated stream inflow to San Luis Valley was about 3.6 times the inflow in the dry year 1951, but the inflow to the Middle Valley (measured at Otowi Bridge) was 6.7 times as great in 1941 as in 1951.

In years of severe or protracted drought, the streamflow available for diversion into San Luis Valley is insufficient for the requirements of subirrigation of crops. Wells have been pumped to overcome this deficiency, and the pumping has created both local and regional problems. A local problem can be visualized where a man having a primary right to surface water is striving mightily to build up the water table for subirrigation, while his neighbors lacking similar rights are pumping water for irrigation and pulling the water table down in the process; such cross purposes can breed cross neighbors. A regional problem is exemplified by 1952, when the depletion of the Rio Grande in San Luis Valley was 11/4 million acrefeet, greater than in any other year and attributed in part to replenishment of the unconfined aquifer which had been pumped heavily in the preceding 2 years.

\section{SURFACE RESERVOIRS}

Without doubt a reservoir at Elephant Butte was desirable for regulation of the natural flow of the river, but it became essential after the development in San Luis Valley, because that development caused significant river depletion without providing any stabilization of the flow remaining in the river. After it was completed in 1915, Elephant Butte Reservoir released at least 650,000 acre-feet of water each year until 1951, although the annual inflow to the reservoir was less than 500,000 acre-feet in 9 of those years. In 40 years of operation, during which the average inflow was nearly a million acre-feet a year, Elephant Butte proved to be capable of storing for subsequent use all the surplus waters of wet years except during the consecutive years 1941-42. After the filling in 1942 , the reservoir was able to provide practically normal supplies for irrigation for 8 consecutive years, during which the inflow was equal to the long-term average in 1944, 1948, and 1949, slightly less than average in 1945 , and less than 50 percent of average in the other 4 years. By 1951, however, nearly all the carryover storage had been used, and water requirements for irrigation in the Rio Grande project could be met only where water could be pumped from ground-water reservoirs.
There is little surface-reservoir capacity above Elephant Butte Reservoir. Reservoirs on tributaries to San Luis Valley have aggregate capacity slightly greater than 370,000 acre-feet, but 142,000 of this is in the basins of Costilla, Culebra, and Trinchera Creeks, whose water supplies have long been completely utilized within their basins and contribute practically nothing to the Rio Grande. Even less storage is available for use in the Middle Valley, which is limited essentially to the 200,000 -acre-foot capacity of the Middle Rio Grande Conservancy District's El Vado Reservoir.

\section{RINCON, MESILLA, AND EL PASO VALLEYS}

The development of the ground-water reservoirs in the valleys downstream from Elephant Butte was spurred by the deficiency of surface supplies during the recent Southwest drought, just as the development of Elephant Butte Reservoir was spurred by the deficiency of runoff in an earlier drought. On the basis of ground-water studies, confirmed by the record for the dry years 1951-56, Rincon, Mesilla, and El Paso Valleys have ground-water reservoirs of sufficient capacity to provide supplementary supplies for at least several consecutive years of deficient streamflow.

Pumping in Rincon and Mesilla Valleys may be responsible for increased loss from canals of the Rio Grande project below Caballo Dam. These transmission losses were low before 1950 but had increased to about 65 percent in 1955 and to 75 percent in 1956. The increasing conveyance loss is indicated also by the fact that 544,000 acre-feet released in 1952 was sufficient to provide 2.75 acre-feet per water-right acre, but 247,000 acre-feet released in 1956 provided only 0.3 acre-foot per water-right acre. Reduction in drain outflow has been accompanied by increasing salinity of soils and shallow ground water, because of accumulation of salts that had been dissolved in the water applied for irrigation. Essentially the farmers in Mesilla Valley with their wells have developed a new reservoir having a capacity that may be on a par with that of Elephant Butte Reservoir, and have assured themselves of supplies throughout a drought that overtaxed the regulatory ability of Elephant Butte. In such a development there is also a possibility of creating problems of salt accumulation and of reservoir depletion that may continue to be troublesome even after increased supplies again become available from the river-both in Mesilla Valley and in deliveries of water to users farther downstream. However, the rapid refilling of the Mesilla Valley groundwater reservoir in 1958 (fig. 7) is an encouraging sign that the present development does not exceed the capabilities of the system for perennial yield. 
Conover $(1954$, p. 3) concluded in advance of the recent ground-water development that-

in a hypothetical year having only 50 percent of a normal supply of surface water available for diversions, the project lands would require an additional acre-foot per acre of water from wells to assure successful irrigation of the crops. However, because of the reduction in flow of the drains caused by pumping and because of losses in distribution, the use of water from wells to supply this deficit would require pumping 2.42 acre-feet per acre, or 213,000 acre-feet a year for the 88,000 acres of water-right land in New Mexico. Of the amount pumped, it is calculated that all but 63,000 acre-feet would be diverted from surface-water flow. If supplemental pumping were resorted to for 5 successive dry years, continued pumping would be necessary for 3 to 4 years after a return to normal surface supply so as to permit bypassing of the required share of water to the El Paso district, awaiting the restoration of ground-water storage by recharge from surface water.

The 5 dry years hypothesized by Conover occurred in 1951-56.

Obviously not all the seepage from streams into ground-water reservoirs can be attributed to pumping from wells, and the evaluation of the proportions of river losses due respectively to natural causes and to man's activities requires a large amount of hydrologic data and a good working knowledge of the interrelations of surface and ground water. Partial information concerning these relations commonly raises more questions than it answers.

In spite of the complex problems in water regulation generated by the recent utilization of ground-water reservoirs, more complete and more flexible utilization of the water resources is possible because of groundwater development. The combined capacities of surface and subsurface reservoirs are sufficient to overcome the effects of long and intense droughts. On the other hand, with the total facilities for storage now available, it is unlikely that Fort Quitman will again see annual runoff as great as a million acre-feet from the upper basin.

\section{CONSUMPTIVE WASTE AND WATER SALVAGE}

Consumptive waste, or "nonbeneficial consumptive use," of water has been a major problem throughout the upper Rio Grande basin for a long time. It was concluded during the Rio Grande Joint Investigation (National Resources Committee, 1938, p. 92, 121) that in 1936 the streamflow depletion by irrigated acreage-the "directly beneficial consumptive use"-was slightly less than half the total streamflow depletion in the upper Rio Grande basin; the other half was due to evaporation from water surfaces and bare lands, and especially to transpiration by native vegetation, which was responsible for the great bulk of the consumptive waste. The San Luis section, Middle section, and Elephant Butte-Fort Quitman section were each responsible for about one-third of the total consumptive waste from the upper basin. The computations for San Luis Valley alone in 1936 were 476,000 acre-feet of water used by irrigated lands and 636,000 acre-feet consumed nonbeneficially; similar data are not available for subsequent years.

In each of the principal valleys of the upper Rio Grande there are extensive areas where the water table is less than 10 feet below the land surface, and where conditions are therefore favorable for consumptive waste of large quantities of water by evaporation and by transpiration of native vegetation. In several areas the shallow ground water is part of the natural environment, maintained in large part by the river even before the advent of white man, and forming swampy areas or "bosques" having a dense cover of vegetation. A sample of this environment is preserved for future generations in the Bosque del Apache National Wildlife Refuge north of San Marcial, N. Mex.

In most areas where surface water has been used for irrigation the water table has risen to within a few feet of the surface, some irrigated lands have become waterlogged, and drainage systems have been constructed to lower the water table. In San Luis Valley the construction of drains began in 1910, and their general effect has been to lower the water table a few feet without changing its form, and to maintain it at a more or less uniform depth under the drained area; in July 1936 (National Resources Committee, 1938 , p. 13,226 ) the depth to water was less than 5 feet in most of the irrigated area of San Luis Valley. In the irrigated lands of the Middle Valley Conservancy District the water table became high during years of abundant water supply in the 1920's and necessitated construction of an extensive drainage system, which was completed between 1930 and 1935 . In 1936 the water table over the entire district was 3 feet lower, on the average, than in 1927 before the drainage construction. Even so, the depth to water in October 1936 was less than 4 feet in 15 percent of the total valley area, less than 6 feet in 61 percent, and less than 8 feet in 89 percent of the Middle Valley. In Mesilla and Rincon Valleys the average depth to water prior to 1950 was 9 to 10 feet in the winter, and 1 or 2 feet less during the irrigation season; this annual cycle, with minor variations, has been observed since water levels in wells were first measured in 1925.

During the period of the Southwest drought, the water table has been lowered by pumping in many valley areas that had previously been irrigated ex- 
clusively by surface water, as in San Luis Valley (fig. 4), Mesilla Valley (fig. 7), El Paso Valley, and doubtless several localities in the Middle Valley. It is assumed that consumptive waste in these areas also has been reduced, but quantitative data are not available.

Drought was one factor that led to the construction of a low-flow channel and cleared floodway for the Rio Grande in a reach of 71 miles above the Elephant Butte Reservoir for the purpose of reducing consumptive waste and thus salvaging water for the Rio Grande project. The low-flow channel, of which 31 miles was completed by 1954 , has a capacity of $2,000 \mathrm{cfs}$ and traverses an area of shallow water table and high consumptive waste by phreatophytes. In 1955 the inflow to Elephant Butte Reservoir was about 45,000 acre-feet greater than would be expected on the basis of stream-depletion data before the channelization. Part of this water was salvaged from consumptive waste and part was a nonrecurring benefit that resulted from dewatering sediments along the channel.

As pointed out by Robinson (1957, p. 1), "phreatophytes are plants that depend for their water supply upon ground water that is within reach of their roots. Although not confined to the arid regions of the western United States, their occurrence there is commoner, more spectacular, and, because of their effect on water supply, more important than it is in humid or subhumid regions." In the upper Rio Grande baisn, phreatophytes are responsible for most of the consumptive waste of ground water and thus for a large part of the total streamflow depletion. Phreatophytes include many types of plants not genetically related and whose only common bond is their penchant for using ground water. Included in the group are the cottonwood and willow trees that are well-known markers for watercourses throughout the West. Alfalfa is probably the phreatophyte of greatest economic value, and its high consumption of water is always rated as "beneficial consumptive use" rather than the "consumptive waste" charged to most phreatophytes.

In the Rio Grande basin, by far the most abundant, prolific, and aggressive phreatophyte is the saltcedar (Tamarix gallica and T. pentandra). Saltcedar is in direct competition with man for the limited water supplies of the Rio Grande, and so far has been winning. Saltcedar was first observed in New Mexico in 1910 in Mesilla Valley. By the time of the Rio Grande Joint Investigation in 1936 saltcedar covered about 5,500 acres in the Middle Valley; in 1947 a survey by the U.S. Bureau of Reclamation showed an infested area of about 26,000 acres, and by 1960 the area of infestation had increased to about 60,000 acres in the Middle Valley and tributaries. The significance of saltcedar in this report on drought in the Southwest is that the increasing area and density of infestation, and the accompanying increase in consumptive waste of water, have been going on throughout the drought period. Some of the shortage of water for beneficial use during these dry years was thus caused by saltcedar rather than by climatic fluctuations.

\section{QUALITY OF WATER}

According to analyses made throughout the year 1936, the water in the Rio Grande at Del Norte was of excellent quality-a natural calcium bicarbonate water containing less than $100 \mathrm{ppm}$ of dissolved solids. At Fort Quitman at the other end of the upper basin, in that same year, the water had more than $2,000 \mathrm{ppm}$ of dissolved solids, chiefly sodium chloride and sulfate. Thus the problems of water quality are concentrated in the lower part of the basin. Broadly speaking, the deterioration in quality is another aspect of aridity. Evapotranspiration within the upper basin-consumptive use plus consumptive waste-accounts for more than 90 percent of the runoff produced in the basin; all the materials dissolved by that water remain behind, in surface water or ground water, or in soil or rock material.

The progressive increase in total salt concentration of the river water from the upper to the lower limit of the basin is shown in figure 8. Weighted annual averages of dissolved solids of the Rio Grande since 1946 show that the water leaving San Luis Valley near Lobatos and that entering the Middle Valley at Otowi Bridge are calcium bicarbonate waters having dissolved-solids contents less than $300 \mathrm{ppm}$ and changing little from year to year. At San Acacia in the Middle Valley, and at San Marcial at the head of Elephant Butte Reservoir, the concentration of dissolved solids is ordinarily at least twice as great as at the Otowi Bridge and there is a marked increase in sulfate, largely reflecting the occurrence of gypsum in the drainage basin tributary to the Middle Valley. The average concentration at both stations varies appreciably from year to year; it was $600 \mathrm{ppm}$ or more in 1934, 1940, 1951, and 1954, all drought years of low runoff, and it was less than $400 \mathrm{ppm}$ in 1942 when runoff was high.

The graph for El Paso (fig. 8A) represents the water available for irrigation on the lower part of the Rio Grande project and in the vicinity of Juárez, Mexico. The water is more mineralized than that coming into Elephant Butte at San Marcial, chiefly because of increase in sodium and chloride. The 


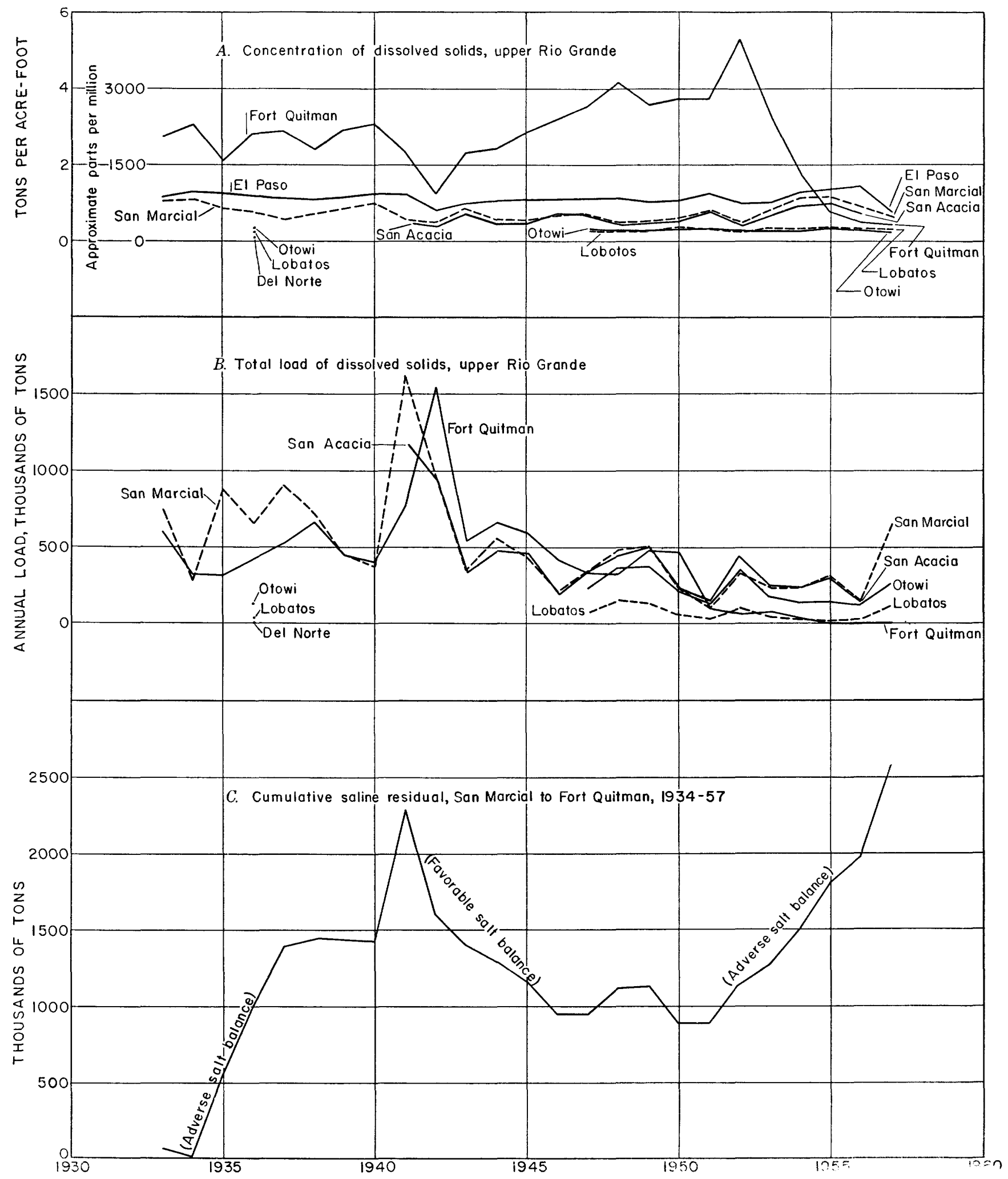

Fradrm 8.-Fluctuations of concentration and total load of dissolved solids in the upper Rio Grande, 1933-57; also cumulative saline residual between San Marcial and Fort Quitman. 
records for El Paso show the stabilizing and mixing effect of Elephant Butte Reservoir, for in 20 years the water has contained an annual average of 1.0 to 1.2 tons of dissolved solids per acre-foot, except in wet 1942 when the content dropped to 0.8 ton per acre-foot, and in the dry years 1934, 1935, 1940, 1951, and 1954 when it exceeded 1.2 tons per acre-foot. The water in the river at Fort Quitman has a high concentration of sodium chloride, but has a far lower concentration of the less soluble calcium carbonate and sulfate than at San Marcial.

Figure $8 B$ shows the fluctuations in total load of dissolved solids at various gaging stations along the river. The graphs, representing the product of total runoff (fig. 2) times concentration, show that the greatest load of dissolved matter is carried in years of high runoff, and the least in years of drought. The total load carried into Middle Valley at Otowi during drought years $(1950-52)$ is almost as great as the total carried into Elephant Butte Reservoir; even in years of average runoff (1948-49) three-fourths of the total entering the reservoir originated above Otowi.

Comparison of the graphs of total load at San Marcial and Fort Quitman indicates the relation of salt inflow to and outflow from the Rio Grande project. Differences between these amounts (fig. $8 C$ ) indicate an increasing residue of salt left in the project area prior to 1941, a decrease from 1942 to 1946, and essential balance from 1947 through 1951 . During the drought years since 1951 there has been a return to unfavorable salt balance, similar to that in later years of the 1930-40 drought. Wilcox (1957) shows that the salt balance in Rincon Valley was favorable (that is, output exceeded input) in 17 of the years 1934-53, but Mesilla Valley had a favorable balance in only 11 of the 20 years. Input exceeded output, and salts accumulated in Mesilla Valley in the drought years 1934-36, and in 5 of the 7 drought years 1947-53. In confirmation, Chang (1957) has tabulated the limited evidence that there has been a general increase in salinity of solids of Mesilla Valley in the period 1949-54.

The Hudspeth County Conservation and Reclamation District, southeast of El Paso Valley, is most widely affected by salinity; Chang reports that 75 to 80 percent of the 13,000 acres has saline or saline-alkali soils. The use for irrigation of drainage water from the Rio Grande project lands has been a contributing factor in the past accumulation of salts here. However the supply of waste water dwindled to 3,800 -feet in 1955 and practically none in 1956, so that twothirds of the district land was abandoned. The re- maining 5,500 acres was irrigated by some 57 wells, and these have created another problem in quality. Lyerly (1957) reports that the average salt content of wells in lower El Paso Valley in 1954 was 3.2 tons per acre-foot of water, with a range from $11 / 2$ to $71 / 2$ tons per acre-foot. In Hudspeth County in 1955 the salinity of well water ranged from $2 \frac{1}{2}$ to 10 tons per acre-foot, and the average was about 5 tons; this average increased to $51 / 2$ in 1956 . Such high-salinity waters are classified as unsuitable for irrigation in standards published by the U.S. Salinity Laboratory (1954). Lyerly (1957) states that if water contains 3 tons of salt per acre-foot, at least as much water is needed for carrying salt residues below the root zone as is needed for irrigation of a crop; and if the salt content is 4 tons per acre-foot, the water requirement for leaching is 3 times the irrigation requirement. With water of still higher salinity, maintenance of yield even of moderately salt-tolerant crops may be impossible.

The effects of drought upon the lower El Paso Valley include (1) reduction in surface water available for irrigation; (2) reduced outflow of soluble salts, as shown by measurements at Fort Quitman, and consequent accumulation within the valley; (3) increasing use of ground water, which has been derived in part from water applied for irrigation and is therefore more saline than the surface water originally used; and (4) excess application of water to leach the salts from the soil, thus further increasing the content of salt in the ground-water reservoir. These processes lead to progressive deterioration of the irrigation enterprises, and explain why two-thirds of the area has been abandoned in recent years. Lyerly concludes that the seriousness of the salinity problem which has developed because of prolonged drought cannot be overemphasized.

\section{RECAPITULATION OF ASSETS AND LIABILITIES}

To summarize the preceding paragraphs, a major asset of the upper Rio Grande is the facilities for water storage, partly in surface reservoirs but dominantly in ground-water reservoirs. These were tapped during the drought and served to offset the deficiencies in rainfall and runoff. The efforts to utilize all available water, including that in surface and subsurface reservoirs, were so successful that outflow from the upper basin was reduced to negligible quantities in the years 1951-57.

A major liability of the upper Rio Grande is the mineral matter dissolved by the water, which prior to 1951 was carried in the outflow at an average rate exceeding half a million tons a year. With practical cessation of outflow in 1951-57 this elimination of 
wastes also stopped. And although this cessation has so far occurred only in drought, it could become chronic if storage and use of water in the upper basin were such as to inhibit outflow even in periods of abundant rainfall and runoff. Of course, even under the best of conditions the outflow carries only a part of the total solids dissolved by water within the upper basin; the remainder accumulates wherever water is consumed and returned to the atmosphere: in irrigated soils, and if leached by application of additional water, then in underlying ground-water reservoirs; and in areas of shallow water table, including notably the closed basin in San Luis Valley.

Consumptively wasted water must be listed as a liability, in that it promotes deterioration of soils and of ground water because of accumulation of saline residues; but it can be converted to an asset wherever means can be found for salvaging the water for beneficial use. Carrying of saline residues to places where they can do no harm could well be included among the beneficial uses of water.

Many of the problems that have loomed large during the drought have been studied extensively, and some have been found to be complex, but physical solutions are possible for most of them. Physical solutions, however, are not enough: a practical solution must conform to the systems that have been established and accepted by the people of the basin for apportionment of the water and for regulation of water use -or alternatively those systems must be modified to embrace management of the water resource for optimum use. In summarizing the problems of the upper Rio Grande, Duisberg (1957, p. 68) states:

The water problem is more than a matter of drought and it is apparent that shortages to existing works will continue even under conditions of normal precipitation. It is also obvious that central problems such as establishing a practical relationship between ground- and surface-water use, developing a policy for the retirement of marginal land and land about to be permanently ruined, creation of means for encouraging and applying the results of research, and informing the people throughout the watershed of their mutuality of interest, must be faced.

To date, intrariver relationships between projects have been characterized by self-righteous attitudes, dependence on legal force, and a search for legal loopholes. The confusion created by the Supreme Court ruling of 1957 in the Texas-New Mexico suit may encourage those who think in terms of loophopes, and technicalities, to the point of destroying any future basis for trust and cooperation between the projects. On the other hand, each state has a moral obligation as a signatory of the Compact regardless of technicalities. It has been suggested that certain changes in the Rio Grande Compact would be both realistic and fair in the light of experience of the past 16 years. This may be an opportune time for these to be considered. Eventually, however, the people of the Rio Grande Watershed must recognize the necessity of closer working relationships between the major sections than is envisioned by the Compact. In working out these relationships they may well have to initiate concepts and ideas never tried before anywhere else.

\section{INSTRUMENTS OF MANAGEMENT FOR SUSTAINED YIELD}

Among the very early titles to land in the Southwest are those granted by the King of Spain before 1821 and by the Government of Mexico before 1848; and of these the "pueblo colonization" grants are of especial interest here because they have been interpreted in some jurisdictions to include a right to the water needed for the future growth and expansion of the pueblo. Such rights would doubtless encourage colonization of an arid region, but as the use of water increases toward the limit that can be sustained by the natural resource the right may become difficult to maintain. In New Mexico the significance of the "open end" of pueblo rights was not realized until a recent decision by the New Mexico Supreme Court (Cartwright et al v. Public Service Co. of New Mexico) which construed the pueblo rights of Nuestra Senora de Las Dolores de Las Vegas, predecessor of the Town and City of Las Vegas, N. Mex.

Generally in New Mexico as well as in Colorado, water rights are based upon the appropriation doctrine, and are thus on the basis of priority of beneficial use. The systems of apportionment of water are separate for each State, and apply only to the water users within the respective States. The Rio Grande Convention of 1906 (Witmer, 1956, p. 408-412) and the Rio Grande Compact of 1938 (Witmer, 1956, p. 154-177) together constitute the basis of apportionment of the water among the States of Colorado, New Mexico, and Texas, and the United States of Mexico.

The Rio Grande Compact of 1938 apportions the water of the river among the three natural divisions of the upper basin described on pages D4-D16. ${ }^{2}$ Under

2 As pointed out in the decision on El Paso County Water Improvement District no. 1 v. $E l$ Paso, 133 F. Supp. 894 (D.C.W.D. Tex., 1955, p. 909): This Compact has a number of peculiar provisions. For example, the water New Mexico must pass to Texas is delivered not where the two States meet, but at San Marcial, New Mexico, more than 100 miles above the point where the Rio Grande leaves New Mexico. This delivery is made into the reservoir of the Elephant Butte Dam, the principal structure of the Rio Grande Project. Some of this water eventually goes to Mexico. The Com. pact, instead of leaving the Texas share of the water open for disposition under the general water statutes of Texas, plainly directs same for irrigation in the Project. A large part of the Project lands are in New Mexico and, consequently, this water delivered to Texas goes to irrigate not only Texas lands, but also New Mexico lands in the Project. The apparent reason for all this is that when the Compact was negotiated, the Rio Grande Project, in all of its far flung works and physical properties was, and for some time had been, superimposed on the Rio Grande and its adjoining valleys all the way from the Elephant Butte Reservoir in New Mexico to a point below Fabens in Texas and that fait accompli colored the whole Compact as between New Mexico and Texas. Perhaps the problem was handled in the only practicable way. 
its terms, Colorado is obligated to deliver to New Mexico water in the Rio Grande as measured near Lobatos, Colo., in each calendar year, on the basis of the flow as measured at specified index gaging stations in the headwaters and a relation that had been established between the flow at those stations and the flow near Lobatos, representing the outflow from San Luis Valley. Similarly New Mexico (that is, the Middle Valley) is obligated to deliver water to Elephant Butte Reservoir in accordance with a relation between the measured flow in the Rio Grande at Otowi Bridge (adjusted for storage as specified) and inflow to the reservoir as established by past records. The compact includes provisions for annual credits and debits, and for accrual of these credits and debits up to specified limits. Basically the compact undertakes to maintain the status quo by allocating to the three divisions of the upper Rio Grande basin the same proportionate flows at all stages of the river that had been received by those divisions over a period of years (1928-37) before the negotiation of the compact. Its provisions are not dependent upon storage, because they do not guarantee specific quantities to anyone (except indirectly by recognizing the obligations of the United States to Mexico and to Indian tribes). It recognizes existing surface storage, however, and includes some provisions pertaining to it. It also permits the development of additional storage, so long as that development does not reduce the proportional supplies available to the division downstream.

The terms of the compact have not been met during the recent years of drought. As of early 1957 the total unofficial debit of Colorado to New Mexico was about 350,000 acre-feet, and that of New Mexico to Texas about 530,000 acre-feet, although the compact states that Colorado's accrued debit must not exceed 100,000 acre-feet, and New Mexico's must not exceed 200,000 acre-feet, at any time. Texas in 1951 brought suit to force New Mexico to deliver debit water, but this suit was dismissed in February 1957 by a ruling of the U.S. Supreme Court, which did not touch on the legality of the compact or the validity of Texas' interpretation, but held that the United States Government should have been an indispensable party to the suit by virtue of its administration of 8,000 acres of irrigated Indian lands and its ownership of various structures in the Rio Grande Project. Thus the enforceability of the compact is in doubt.

Because of the shortage in deliveries of water from Colorado and from New Mexico, Mexico has in some years received less than the 60,000 acre-feet annual allotment under the terms of the Treaty of 1906 . The treaty provides that in case of extraordinary drought Mexico's quota may be diminished in the same pro- portion as the water delivered to lands on the American side, and accordingly Mexico received about 8,200 acre-feet in 1955 and 7,800 in 1956. In recent years more than 25,000 acres of formerly irrigated land in Juárez Valley has been abandoned or retired from production; about 27,000 acres has been irrigated from wells and only 2,500 from the river.

Although perhaps 90 percent of the water users in the upper basin-including those in New Mexico, in Texas, and in Mexico-received during the drought less than the share of water that was apportioned to them by interstate and international agreements, relatively few were forced to abandon their enterprises that depended upon water. Many were able to continue through the drought years with no diminution of water supply, because of development of ground water. This development and use of ground water, and the close physical relation of ground water to surface water, were responsible at least in part for the inability to apportion water in accordance with the provisions of compact and treaty. These instruments specify the apportionment of surface water among States which, at least in the first several years of drought, did not undertake to regulate the use of ground water in the upper basin. This situation is now rectified in part by the New Mexico State Engineer, who has declared the entire Rio Grande valley in New Mexico to be subject to regulation of all water development and use, both surface water and ground water (Reynolds, 1958, p. 15-28).

At all levels of administration of the water-rights system governing apportionment in the basin, there are opportunities for rigidity of operation that tend to paralyze the upper Rio Grande basin's water economy, but there may be opportunities also for modifying the present pattern so as to achieve more effective use of the water resource. For example, it is fundamental in the appropriation doctrine to recognize and protect the earliest rights in perpetuity, even though they require use of water that seems wasteful or damaging in the light of the present economy; a less rigid concept would be to recognize such rights as analogous to other property rights, not necessarily sacrosanct but capable of exchange, adjustment, or purchase on the basis of their actual economic value. Some readjustment of water-use pattern may be desirable, for instance, in San Luis Valley where contiguous surface-water "subbers" and ground-water pumpers work at cross-purposes, yet where there are doubtless some areas in which the physical characteristics of soil and subsoil are better suited to irrigation by pumping, and others to subirrigation, in years of less than average inflow to the valley. 
As a problem of larger dimension, it would be desirable to incorporate the unconfined aquifer of San Luis Valley into the Rio Grande reservoir system, so that it could discharge water for the benefit of downstream users, rather than for consumptive waste in the closed basin. This problem has been studied extensively and a projected network of drains, analyzed by the U.S. Bureau of Reclamation, would salvage a quantity of water estimated at 19,000 to 33,000 acre-feet annually (Powell, 1958, p. 112-117). But evapotranspiration from the closed basin has continued for so long that there is now a considerable accumulation of salt in the soil and water. The findings of the Rio Grande Joint Investigation (National Resources Committee, 1938, p. 123-126) were that the water initially salvaged by a gravity drain might carry $1 \frac{1}{2}$ tons of salt per acre-foot, "with a remarkably unfavorable preponderance of sodium combinations in its constituent parts," and according to Howard (in Powell, 1958, p. 110) this is the quality than can be expected in the specific drain system proposed. This is approximately equivalent to the average quality of water entering Elephant Butte reservoir since 1953 , and is considerably better than the water leaving the upper basin at Fort Quitman in most years. However, the Rio Grande Compact of 1938 includes in its Article III a proviso concerning any water salvaged from the closed basin:

In event any works are constructed after 1937 for the purpose of delivering water into the Rio Grande from the Closed Basin, Colorado shall not be credited with the amount of such water delivered, unless the proportion of sodium ions shall be less than forty-five percent of the total positive ions in that water when the total dissolved solids in such water exceeds three hundred fifty parts per million.

Studies in recent years have therefore led to proposals that would leave the salt and the sump as they are, but intercept water by means of wells where it is still of good quality, and divert that water to places of use (U.S. Bureau of Reclamation, 1956).

\section{LOWER RIO GRANDE}

The effect of the recent drought upon volume of streamflow in the lower Rio Grande is indicated by figure 9: the runoff in the Rio Grande at Rio Grande City, Tex., was lower in 1950, 1951, and 1952 than in any year since records began, and in the minimum year 1952 was only about 20 percent of the 1924-53 mean. But even in 1952, according to the International Boundary and Water Commission, 100,000 acre-feet of unused streamflow passed the lowest diversion works at Brownsville, Tex. In the 30 years 1924-53 the average unused streamflow passing that point was about $2 \frac{1}{2}$ million acre-feet. As in other basins, the fluctuations in supply in the lower Rio Grande basin create difficulties in providing adequate flows for developed requirements, but these difficulties are less than in basins where the total requirements are a larger proportion of the mean river flow. Many difficulties of the past are now alleviated by storage and regulation in surface reservoirs in Mexico with total capacity (at spillway level) of $4,665,000$ acrefeet, and in the international Falcón Reservoir 85 miles downstream from Laredo, which was completed in December 1952 and has a capacity of $3,350,000$ acrefeet.

The average annual runoff from the upper basin at Fort Quitman in the 32 years $1924-55$ was about 204,000 acre-feet, compared to an average for the same years of 195,000 as measured at the Upper Presidio, Tex., gaging station, 205 miles downstream from Fort Quitman. The long record from the Upper Presidio station is the basis of the lowest graph of figure 9 . In some flood years, as for example in 1905-07 and 1911-12, the discharge from the upper basin has been of the order of a million acre-feet or more, but that flood discharge represented only 10 to 20 percent of the total discharge of the river near its mouth. Since Elephant Butte Reservoir began operation in 1916, the annual runoff at the Upper Presidio station has ranged from 439,000 to 2,500 acre-feet except in the flood years 1941 and 1942 .

By the time the Rio Grande reaches Langtry, Tex., it is carrying the drainage from a basin more than twice the size of the upper basin alone. The flow is far more than twice the outflow from the upper basin, chiefly because of inflow of the Río Conchos from Mexico. Before the Elephant Butte Reservoir began operation, the years of greatest runoff from the Conchos coincided rather closely with those of greatest runoff from the upper basin.

The records of runoff at Laredo, Tex., and particularly at Rio Grande City, Tex., suggest that the Rio Grande basin below Langtry is in a climatic region distinct and appreciably different from that of the basin above Langtry. At one or both of these stations the runoff was above the $1924-55$ average in several years $(1930,1933,1935,1936,1944)$ when the runoff at Langtry was less than average. The contrast in climatic regions is indicated also by the graphs showing the trends in precipitation in the region below Rio Grande City and in the region between Fort Quitman and Presidio (fig. 9). The periods of greatest precipitation deficiency in the lower Rio Grande valley (below Rio Grande City) were in 1895-1902, 1907-11, and 1917-21, of which only the years 1907-11 were markedly dry in the upper part of the lower basin. 


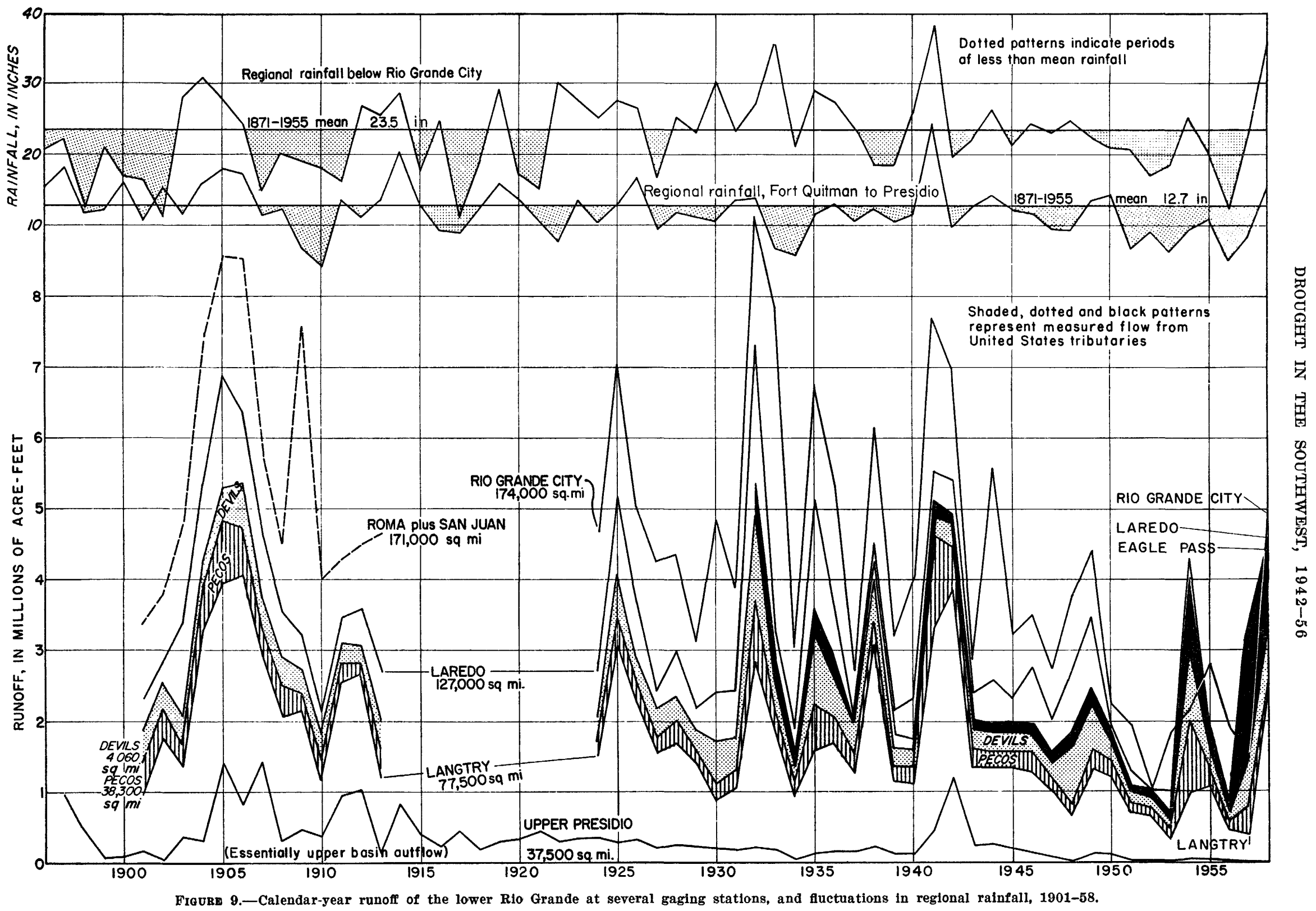


Judging by these graphs, the Southwest drought did not encompass the lower Rio Grande basin until 1951, although precipitation was below average in 1947 and 1948 in the upper part of that basin. Beginning in 1951 the entire basin was affected by drought.

Under the terms of the Rio Grande, Colorado, and Tijuana Treaty of 1944 between the United States of America and the United States of Mexico, the United States is allotted

one-third of the flow reaching the main channel of the Rio Grande (Río Bravo) from the Conchos, San Diego, San Rodrigo, Escondido and Salado Rivers and the Las Vecas Arroyo, provided that this third shall not be less, as an average amount in cycles of five consecutive years, than 350,000 acrefeet annually.

$* * *$ In the event of extraordinary drought or serious acci. dent to the hydraulic systems on the measured Mexican tributaries, making it difficult for Mexico to make available the run-off of 350,000 acre-feet annually allotted $* * *$ to the United States as the maximum contribution from the aforesaid Mexican tributaries, any deficiencies existing at the end of the aforesaid five-year cycle shall be made up in the following five-year cycle with water from the said measured tributaries.

Whenever the conservation capacities assigned to the United States in at least two of the major international reservoirs, including the highest major reservoir, are filled with waters belonging to the United States, a cycle of five years shall be considered as terminated and all debits fully paid, whereupon a new five-year cycle shall commence.

Prior to consummation of the treaty, one-third of the combined outflow of the named Mexican tributaries exceeded 350,000 acre-feet in all years of record except 1934, 1937, and 1940; and this third did not drop below an annual average of 350,000 acre-feet in any period of 5 consecutive years. The Southwest drought began soon after the effective date of the treaty, however; one-third of the combined flow of the named tributaries was less than 350,000 acre-feet in 1945 , 1948 and in each of the 8 years 1950-57. One-third of the annual average flow in the 5-year period 1948-52 was 275,000 acre-feet, and in the following period (1953-57) the comparable average was 210,000 acrefeet.

Most of the contribution from the United States to the lower Rio Grande enters the river between Presidio and Eagle Pass, Tex. Under the terms of the Treaty of 1944, the United States is allotted all the water contributed to the Rio Grande by the following measured tributaries in this reach: Pecos and Devils Rivers, Goodenough Spring, and Alamito, Terlingua, San Felipe and Pinto Creeks. The combined flow of these sources is shown in figure 9 by the shaded, dotted, and black patterns. A substantial part of this total comes from springs issuing from the Edwards Plateau.

\section{EDWARDS PLATEAU}

The Rio Grande traverses the Edwards Plateau from the time it completes its semicircuit around the Big Bend country until after it passes Del Rio. The river gains substantially in this reach by inflow of measured tributaries and by unmeasured inflow, and most of this gain comes from ground water discharged from aquifers underlying the Edwards Plateau.

According to reconnaissance geologic maps (Darton, 1933; U.S. Geological Survey, 1932), the rocks of the Edwards Plateau are chiefly in the Comanche series of Early Cretaceous age, and this series includes several limestone formations, of which the Edwards and associated limestones are important aquifers farther east, in the San Antonio region (Thomas and others, 1963a). As described by Roberts and Nash (1918) some of the limestone beds are exceedingly cavernous and honeycombed, and yield abundant supplies of water to wells in the vicinity of Del Rio and Pumpville. However, extensive areas of the plateau, particularly near the Rio Grande, are capped by the less permeable Eagle Ford formation or Austin chalk of Late Cretaceous age. The Lower Cretaceaus rocks also include less permeable sediments, of which the Walnut clay (Del Rio clay of former usage) is an example. Thus, from the meager data now available, the Edwards Plateau apperas to have a major groundwater reservoir which in many places can be readily recharged by precipitation upon permeable limestone outcrops, but which in other places has a relatively impermeable surface from which there is overland runoff during intense rainstorms.

The Rio Grande has cut into the plateau to form bluffs more than 200 feet high both upstream and downstream from Langtry. The Pecos River, Devils River, and other tributaries flow through limestonewalled canyons for many miles before joining the Rio Grande. There are many springs, both large and small, in these canyons, generally at altitudes not far above that of Rio Grande (Roberts, 1918, pl. 1). The concentration of springs within Val Verde County may mean only that here are the topographically lowest outlets available to the ground-water reservoir. However, the geologic structure may also be a factor: as shown by King (1942, fig. 23), the limestones under most of the plateau have a very gentle southeastward dip, but there is a marked structural depression just south of the Rio Grande opposite the mouths of the Pecos and Devils Rivers.

\section{GROUND-WATER STORAGE AND DISCHARGE}

Although there are some wells of high yield in the part of the Edwards Plateau within the Rio Grande 
basin, the total production from wells is very small, either in comparison with pumping from the groundwater reservoir with Edwards limestone farther east (Thomas and others, 1963a) or in comparison with spring discharge from the Edwards within the Rio Grande basin. Judging by records from a few observation wells, chiefly near Del Rio, there have been fluctuations in storage in the ground-water reservoir but no progressive depletion during the recent drought. In well XV-3 (fig. 10) the water level was as high in 1949 and again in 1954 as the maximum stage reached in previous years, notably in 1938 and 1943. Thus there was full recovery from intervening drier years such as 1946, when the level was 7 feet lower, and 1953, when it was 10 feet lower than this maximum stage.

Goodenough Springs are among the largest of the springs that discharge water from the Edwards Plateau, and their discharge has been gaged since 1929. The springs are so close to the Rio Grande that the gaging station is affected by backwater when the river flow exceeds $35,000 \mathrm{cfs}$, but otherwise the record shows natural ground-water discharge. Evidently that discharge is not derived solely from local sources, for the fluctuations do not correspond with those of water levels in wells or of stream discharge in the adjacent Devils River basin. Thus the peak of discharge in 1941, and especially the high discharge of 1946-47, are not replicated by high water levels in the well at Del Rio, or by high discharge in the Devils River (fig. 10). However, water levels and spring discharge were high in both periods in the limestone ground-water reservoir farther east (Thomas and others, 1963a).

The hydrograph showing discharge of Devils River near Juno has many features in common with the graphs of discharge of Goodenough Springs and of water level in the well near Del Rio. The gaging station near Juno, operated from 1926 to 1949 , measured the runoff from the upper two-thirds $(2,730$ square miles) of the Devils River basin. Although there was storm runoff at least once in nearly every year, the discharge is believed to be primarily of ground water from the plateau. In general form the hydrograph for the river is similar to that for the Del Rio well: a gradual decline from 1938 to mid1942, then a sharp rise by the end of that year, followed by a decline until 1945 , little change through 1946 and 1947, and then a rise in the following two years. The chief similarity between the hydrographs of the river near Juno and of Goodenough Springs is in the sharp increases in discharge (generally during periods of storm runoff in the river) and the gradual decline thereafter, following a trend that approaches a straight line on a semilog plot. The lines in successive years are approximately parallel, and those for the river and for Goodenough Springs are also virtually parallel. Troxell (1953) found similar depletion curves in hydrographs for streams in southern California, and attributed them to "perennial ground-water runoff." The depletion curves for Goodenough Springs and for Devils River near Juno indicate that if there were no replenishment to the reservoirs from which these flows are derived, the flows would be decreased by about 50 percent every 2 years.

\section{DEVILS RIVER}

'The gaging station on Devils River at Del Rio ( $41 / 2$ miles above the confluence with the Rio Grande) measures the runoff from 4,185 square miles. Although this drainage basin is only 50 percent larger than that above the Juno gaging station, the discharge is at least 3 times as great, and storm runoff may be more than 30 times as large. Thus the lower third of the Devils River basin is the principal runoff-producing area in the basin.

Devils River is noted for its "constant flow of clear sparkling water that rises in great springs and flows down the Rio Grande in a stream which for many miles keeps separate from the muddy water of the main river" (Darton, 1933). The importance of the ground-water contribution to the river was especially noteworthy in 1933, when rainfall over the drainage basin was only about 50 percent of the long-term mean, and there was no indication of storm runoff at any time, yet the total runoff in 1933 was 50 percent greater than in the wet year 1941, when rainfall was 25 percent above average.

On the other hand, Devils River is capable of tremendous flash floods. The maximum discharge of 597,000 cfs on September 1, 1932, is equivalent to 143 cfs per square mile, a record for drainage basins of its size. In frequency of runoff-producing storms, 1949 was the best year, with eight separate flood peaks between February and October-one in every month except March. Thus, in spite of the large groundwater contribution, the runoff of Devils River ranges widely from year to year, chiefly because of stormflow. Statistics for the period 1924-53 indicate that the mean annual runoff was 406,000 acre-feet, the mean deviation 194,000 acre-feet, and the standard deviation about 164,000 acre-feet (Gatewood and others, 1963).

Casual inspection of the record of runoff of Devils River indicates that the effects of the recent drought have been very marked. In 47 years of record (1901- 


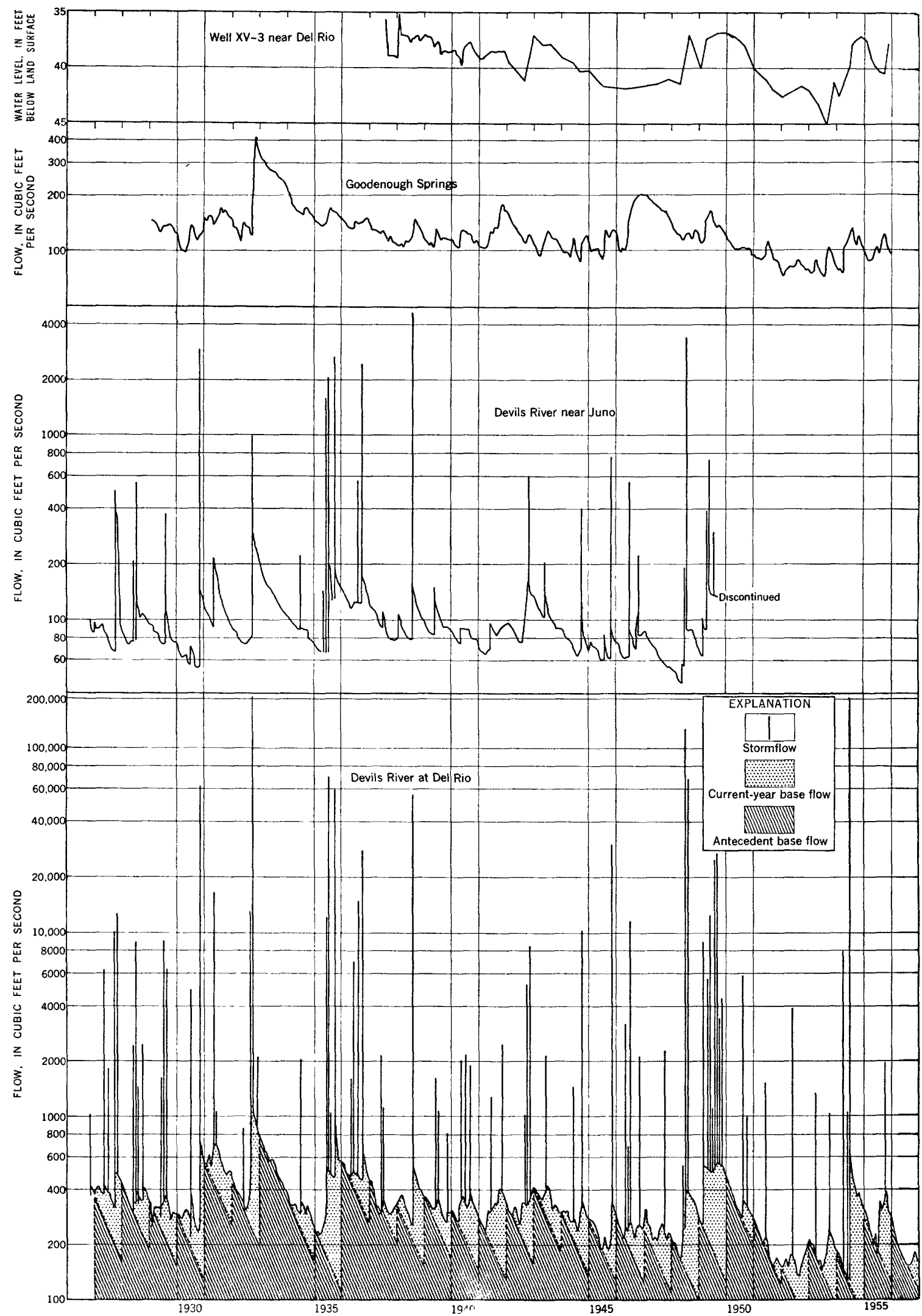

Figure 10.-IIydrographs of Devils River and Goodenough Syings, and water level in a well near Del Rio, Tex., $1927-56$. 
$13,1924-57)$ the 5 years of least runoff were 1956, $1952,1953,1951$, and $1947 ; 1951$ and 1952 were also the years of least precipitation on the drainage basin in the 47 years. However, there is considerable variation in the precipitation-runoff relation from year to year: in 1910 and in 1933, for instance, precipitation was less than in 1953 , but runoff was almost three times as great. There is a similar variation in the relation in wet years: 1932 and 1935 rate first and second in both annual precipitation and runoff, but the third ranking year in runoff (1948) was a year of only average precipitation over the basin. Figure 11 shows the variation in precipitation from year to year, the variation in runoff, and the variable relation of precipitation to runoff.

Doubtless some of the irregularity in the relation of precipitation to runoff can be traced to inadequate data concerning precipitation, which may occur in intense but localized storms. For example, the maximum discharge during 1942-an instantaneous peak of $25,100 \mathrm{cfs}$ and mean daily of $11,900 \mathrm{cfs}$-occurred on November 6 , following 10 days when discharge had been less than $500 \mathrm{cfs}$. The storm responsible for this flood discharge apparently slipped through the net of precipitation stations, for they recorded an average of only 0.58 inch of rain during the entire month of November.

The principal variable in the precipitation-runoff relation, however, is undoubtedly the lag between the time of precipitation and the time of runoff. Some water runs off concurrently-within hours or days, or at least within the same month-with precipitation, but other water is stored in the ground-water reservoir for months or years before it reaches the stream. To analyze the effect of drought upon runoff, it is desirable to discriminate the runoff resulting from concurrent precipitation and the runoff resulting from precipitation in earlier years.

The hydrograph for Devils River at Del Rio (fig. 10) includes many periods of declining discharge when the trend approaches a straight line on a semilog graph, similar to those for Devils River near Juno and for Goodenough Springs. These parallel straight lines represent the rate of depletion of the

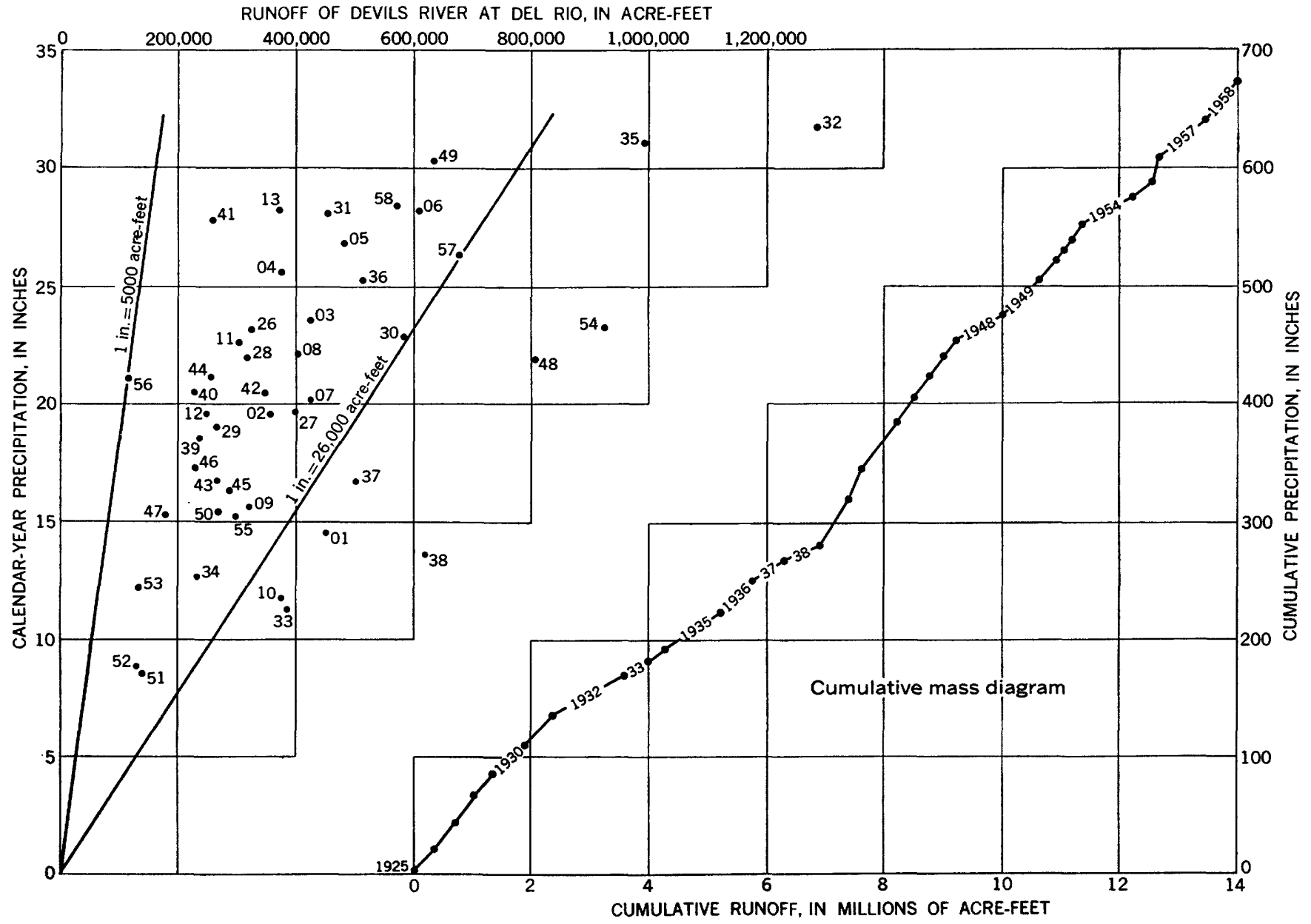

Figure 11.-Relation of Devils River runoff to precipitation on the drainage basin, 1901-58. 
ground-water reservoir, that is, the base flow, during periods of little or no rainfall (Riggs, 1953; Troxell, 1953). Where the recession is a straight line on a semilogarithmic projection, the following formula may be used:

$$
Q_{t}=Q_{o} K^{t}
$$

in which $Q_{t}$ is the stream discharge at time $t$ after a given discharge $Q_{o}$, and $K$, the depletion factor, is a constant that is governed by the characteristics of the drainage basin. On figure 10 , lines parallel to the straight-line recession curves have been drawn through the points representing average flow in December of each year; the part of the discharge below this line in the following year is derived from "antecedent" precipitation. The part of the discharge above this line then includes both base flow and storm flow derived from precipitation during the same year.

The annual runoff of Devils River is shown again in figure 12 , but in arithmetic scale; in this diagram the runoff from current-year precipitation is shown above the baseline, and that from precipitation in earlier years below the baseline. There is improved correlation between precipitation and the runoff shown above the line, particularly in such dry years as 1933 and 1934, but the runoff in wet years is still clearly not proportional to the precipitation during the year of runoff. Rainfall intensity, a factor that cannot be evaluated in the annual totals, is responsible for several of these discrepancies. For example, more than half the total runoff in 1938 occurred in July when rainfall was 5.1 inches; the annual rainfall was only 65 percent of the long-term average. Similarly in 1930 and 1948, when the annual rainfall was only slightly above the long-term average, there were floods following storms of 9.1 and 8.1 inches, respectively, and the runoff during these floods was a major factor in the high total of annual runoff in those years.

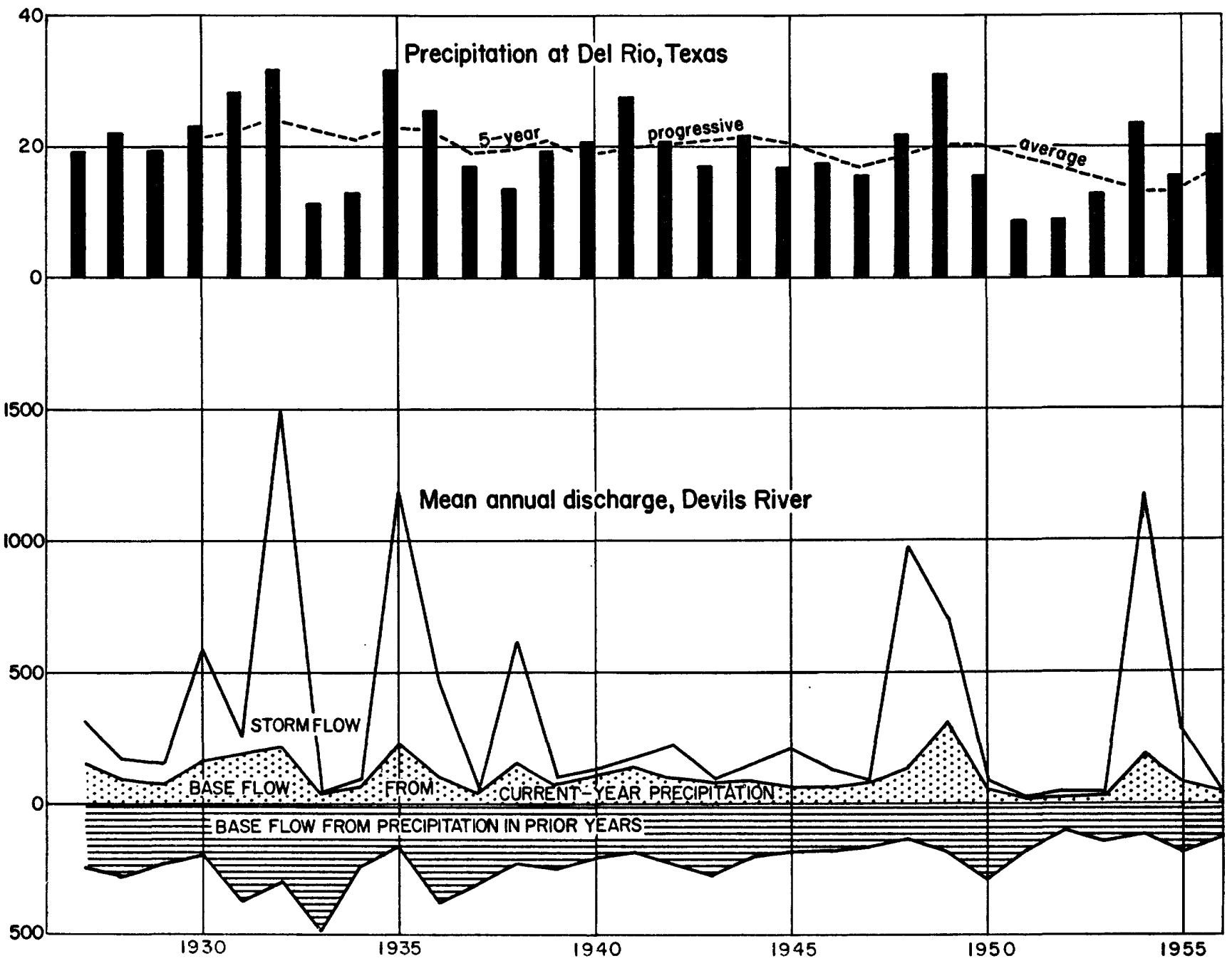

FigURm 12.-Calendar-year discharge of Devils RIver from current and from antecedent precipitation, 1927-56. 
The segregation of runoff into parts derived respectively from current-year precipitation and from antecedent precipitation-even though only a rough approximation-permits evaluation of the relative importance of each. The depletion curve indicates that the ground-water reservoir drains fairly rapidly, so that the discharge would be reduced by half every 10 months if there were no replenishment. The mean monthly discharge was within the limits of 200 and $400 \mathrm{cfs}$ more than half the time in the period 1924-53, and this was achieved by frequent replenishment, involving accretions from precipitation in practically every year-in fact, in almost every month when the basin precipitation exceeded 3 inches. On the other hand, the great variation in precipitation from month to month and year to year would produce far greater fluctuations in runoff but for the carryover effects of ground-water storage, and the delayed discharge from antecedent precipitation. The stabilizing effect of such runoff is seen especially in pairs of wet and dry years such as 1932 and 1933, 1935 and 1936, and 1949 and 1950.

A long-continued drought, such as has prevailed in the Southwest since 1941, reduces the runoff from current-year precipitation, and the runoff from antecedent precipitation also declines. Thus, although runoff may remain fairly uniform through a succession of alternating wet and dry years, a series of dry years necessarily causes a marked and persistent reduction in flow. During two successive dry years, such as 1933 and 1934 or 1950 and 1951, runoff diminishes markedly because of the absence of recharge to the continuously draining ground-water reservoir.

There has been an overall downward trend in runoff of Devils River since the wet year 1932, especially in the driest years-1956, 1951 and 1952, and 1933 and 1934. Reversals in this trend occurred chiefly in the wet years 1935 and 1948-49. In most other years the additions to the basin from rainfall have been enough to balance the outflow. This downward trend is apparent in runoff from current-year precipitation as well as from antecedent precipitation, and it is in accord with that of precipitation: As shown by the 5-year progressive averages on figure 12, precipitation at Del Rio decreased from an average of 23 inches annually in the 5-year period 1931-35 to 13 inches in 1951-55.

\section{UTILIZATION OF THE GROUND-WATER RESERVOIR}

The wells that have been drilled in the part of the Edwards Plateau region within the Rio Grande basin have been sufficient to establish the existence of one or more ground-water reservoirs capable of yielding copious supplies over an extensive area. These wells supply water for domestic and stock use, and some large wells are used for irrigation or municipal supply. The total yield from wells, however, is minor in comparison with the quantity used from springs and streams.

Some of the discharge from springs issuing from the Edwards and associated limestones is used for irrigation, as for example the San Felipe Springs in the vicinity of Del Rio. The area thus irrigated may fluctuate somewhat from year to year, and is subject to the overall limitation imposed by the minimum flow from the developed springs. Users of water for irrigation as well as for hydroelectric power rely upon the stabilizing effect of the ground-water reservoir, which discharges water at far more uniform rates than would be possible by direct storm runoff. Nevertheless the variations in runoff from year to year are considerable, and during extended periods of drought the users of water from springs and streams are restricted to quantities far less than are obtained from those sources in more favorable years.

To what extent can the ground-water reservoir be utilized to provide a stable water yield from the Edwards Plateau region? We haven't the essential data concerning the Edwards Plateau in the Rio Grande basin to give a quantitative answer to this question. Goodenough Springs, for instance, seem to be not closely related to those in the adjacent Devils River basin, and it is possible that they might be less affected by pumping from wells in the vicinity than by pumping as far away as Uvalde. Until the geology and hydrology of the reservoir system are known, the effects of specific developmental projects cannot be predicted reliably.

If we assume that the ground-water reservoir beneath the Devils River basin is a hydrologic unit coextensive with the drainage basin so that all its recharge comes from precipitation within the basin and all its natural discharge also occurs within the basin-then by making best use of the ground-water reservoir, how much water could the Devils River basin yield year after year, on the basis of existing data concerning the climate and hydrology of the basin?

Certainly the sustained yield must be less than the average flow of Devils River-560 cfs or 416,000 acrefeet a year-during the period of record (1924-57), because this average includes flood discharges following storms that exceeded the absorptive capacity of the ground-water reservoir. The storm runoff during these flood years, notably 1932, 1935, 1938, 1948, and 
1954, is responsible for the position of the points farthest from the "normal" precipitation-runoff relation, and for a marked change in trend of the cumulative mass diagram (fig. 11). The upper diagram indicates that, except in these years of greatest storm runoff each inch of rainfall on the drainage basin has produced 5,000 to 26,000 acre-feet of runoff at Del Rio. The cumulative mass diagram indicates that for extended periods (1926-29, 1939-47, and 1950-53) the ratio has been about 15,000 acre-feet of runoff per inch of rainfall. If the long-term average rainfall is 20 inches a year, the average runoff production would thus be of the order of 300,000 acre-feet. Actual runoff was less than 300,000 acre-feet in 16 of the 34 years $1924-57$, but 11 of these were the years 1943-47, 1950-53, and 1955-56, within the most recent drought period.

\section{QUALTTY OF WATER}

The problem of water quality is likely to appear in the lower part of every major river basin, and is likely to become more critical as developments upstream utilize a progressively larger proportion of the flow of the river. The question is especially pertinent to the lower Rio Grande, because much of the water that passes El Paso is of inferior quality (p. D20), and because the Pecos has a drainage basin that is practically a chemical mass-production plant.

Records of the International Boundary and Water Commission (1931-58) show that only a small proportion of the total dissolved load in the lower Rio Grande comes from the upper basin (fig. 13). The annual load in the river at the Upper Presidio station (above the confluence with the Conchos) has generally been less than that at Fort Quitman, the chief exceptions

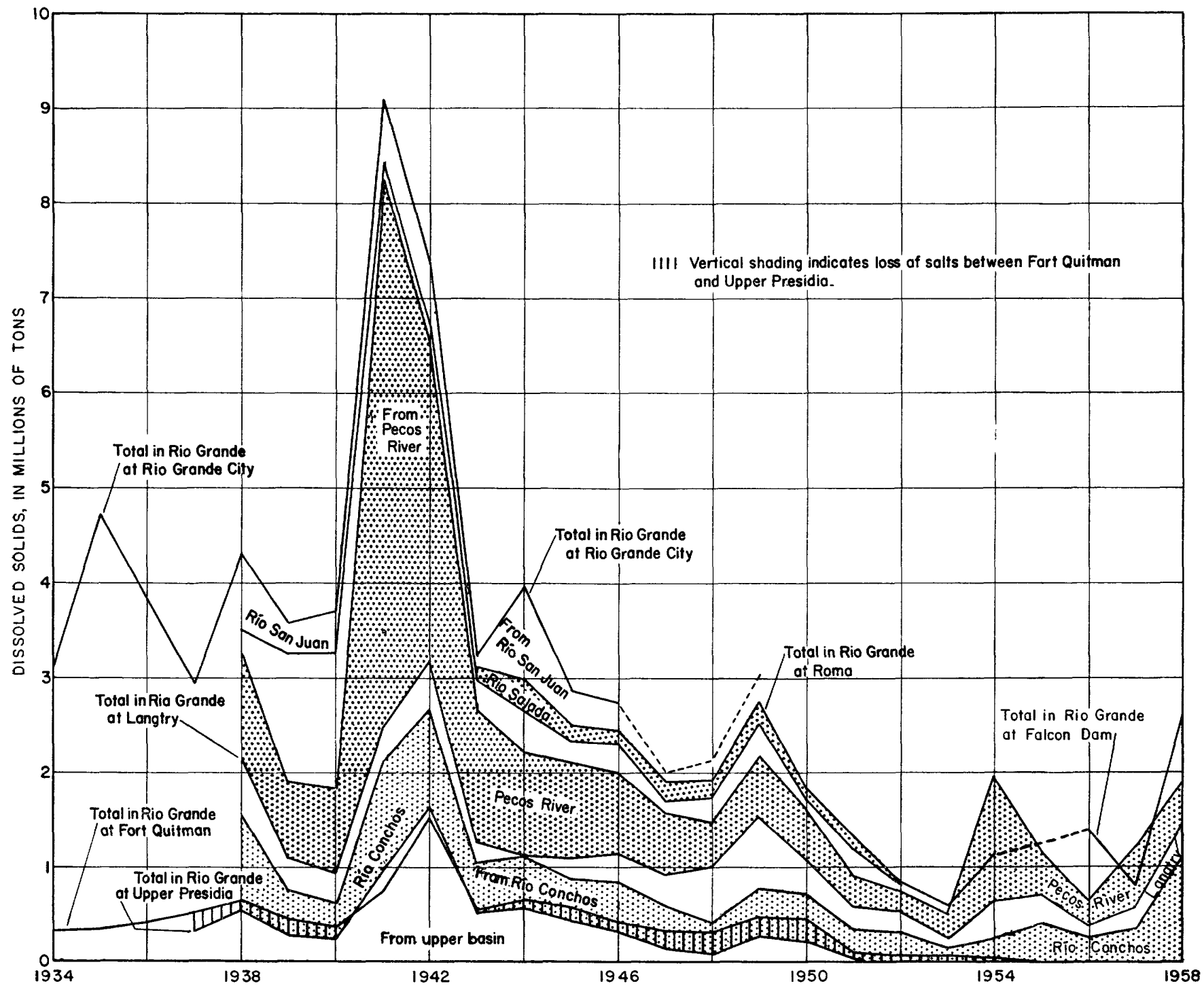

Fygure 13.-Dissolved load in the lower Rio Grande, 1934-58. 
being 1941 and 1942 when the annual flow exceeded 400,000 acre-feet. The Río Conchos regularly carries more dissolved solids than does Rio Grande at the confluence, but it also carries far more water.

The Pecos River is generally the biggest single contributor of dissolved salts to the Rio Grande, although its contribution of water is ordinarily less than that of the Devils River or Río Salado, and only about one-third that of Río Conchos. In 1941 the Pecos River carried $5,800,000$ tons of dissolved salines, equivalent to 64 percent of the $9,150,000$ tons measured in the Rio Grande at Rio Grande City. Largely because of the Pecos River inflow, the dissolved load at Rio Grande City in 1941 and 1942 was more than double the average in the seven previous years. Since 1945 , however, the total tonnage of dissolved material (measured at Roma or at Falcón Dam and thus omitting the Río San Juan) has been less than in any year prior to 1944 .

The concentration of dissolved solids, rather than the total load carried in a stream, is the feature of primary interest to the water uses. As shown by the lowest graph in figure 14, the water available to the lower Rio Grande valley has been of fairly uniform concentration, carrying generally less than a ton of dissolved solids per acre-foot, but with annual averages ranging from 0.5 to 1.2 tons per acre-foot. The water at Roma and Falcón Dam characteristically has a lower concentration of dissolved salts than that coming from the upper basin or from the Pecos River, in- dicating dilution of inflowing waters. This dilution has resulted in water of better quality for irrigation, for the percent sodium at Roma has ranged from 34 to 50 in the past two decades, whereas both the Pecos River and the Rio Grande at Fort Quitman have carried water ranging from 36 to 64 in percent sodium (annual averages).

The river water at Fort Quitman was least mineralized during 1942, the year of greatest runoff since 1915 , and the concentration thereafter trended upward to a maximum in 1952, the first of several years of practically negligible outflow from the upper basin. In the 5 years following 1952 the concentration of salines in the river decreased progressively, doubtless owing at least in part to pumping in the valleys below Elephant Butte Reservoir and consequent reduction of drain flows to the river within those valleys.

The record of samples from the Rio Grande at the Upper Presidio station indicates that the river there not only carries a lesser total load than at Fort Quitman, but that the water generally is also less mineralized. There is generally a diminution of flow between the two stations because of natural evapotranspiration losses and because of diversions for irrigation of some 20,000 acres. These losses of water could account for the lesser total dissolved load at the Upper Presidio station, but we haven't an adequate explanation for the reduction in concentration of the water that passes that station. Perhaps the water diverted for irrigation is more concentrated than the

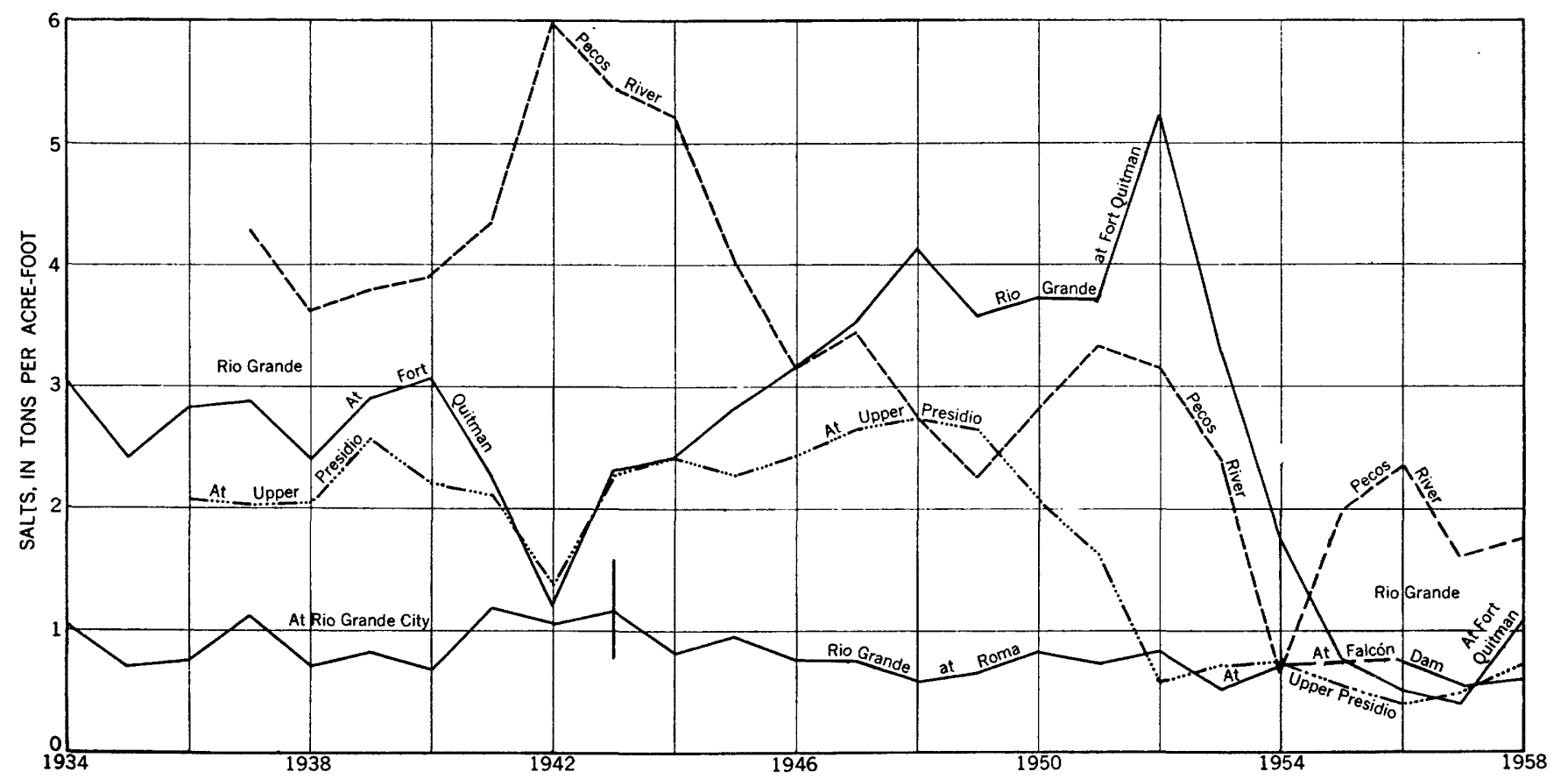

Fig CRE 14.-Concentration of soluble salts in the lower Rio Grande, 1934-58. Quality of water at mouth of river is generally superior to that of waters contributed by the upper Rio Grande and the Pecos River. 
annual average at Fort Quitman, and perhaps the water at the Upper Presidio station includes some increment of storm runoff from the intervening desert drainage area of 3,000 square miles. At any rate, during the recent drought years the upper basin has delivered insignificant amounts of either water or dissolved solids to the lower Rio Grande.

The effect of the recent drought upon suspended sediment load in the lower Rio Grande is shown in figure 15. The concentration of suspended sediment, in percent by weight, fluctuates appreciably from sample to sample, but annual averages are fairly uniform from year to year, both at Eagle Pass and at Roma. The annual sediment load at both these stations thus fluctuates similarly to the runoff (fig. 9). The greatest sediment load in the period of record was carried during the high-runoff years 1935 , 1938, 1941, and 1942, and the least in the drought years 1951 to 1953 inclusive.

\section{PECOS RIVER}

The Pecos River rises in the rugged Sangre de Cristo Mountains of the Southern Rocky Mountains in New Mexico. Its drainage basin of 35,000 square miles is slightly larger than the basin of the upper
Rio Grande (above Fort Quitman). Like the upper Rio Grande basin, the Pecos River basin is conveniently divided into three parts: a headwaters area of 4,000 square miles above Alamogordo Reservoir, a middle area of 16,000 square miles between Alamogordo Reservoir and Red Bluff Reservoir, and a lower area in Texas.

In many respects the Pecos River is quite different from the Rio Grande, and in some respects it is unique among the well-known rivers of the country. Some of the water actually used for irrigation in the Pecos River basin is so saline that it would be classed as unsuitable for irrigation in the rest of the country. A large part of the water in the river is derived from underground seepage, and the stream itself disappears underground for stretches of several miles. The calculated average water production of the upper and middle sections is only about one-fourth of the production of the San Luis and Middle Valley sections of the upper Rio Grande, yet the average discharge of the Pecos River at its mouth has been almost twice the average discharge of the Rio Grande at Fort Quitman.

To some extent climatic variations may be responsible for the contrasts in hydrology of the contiguous
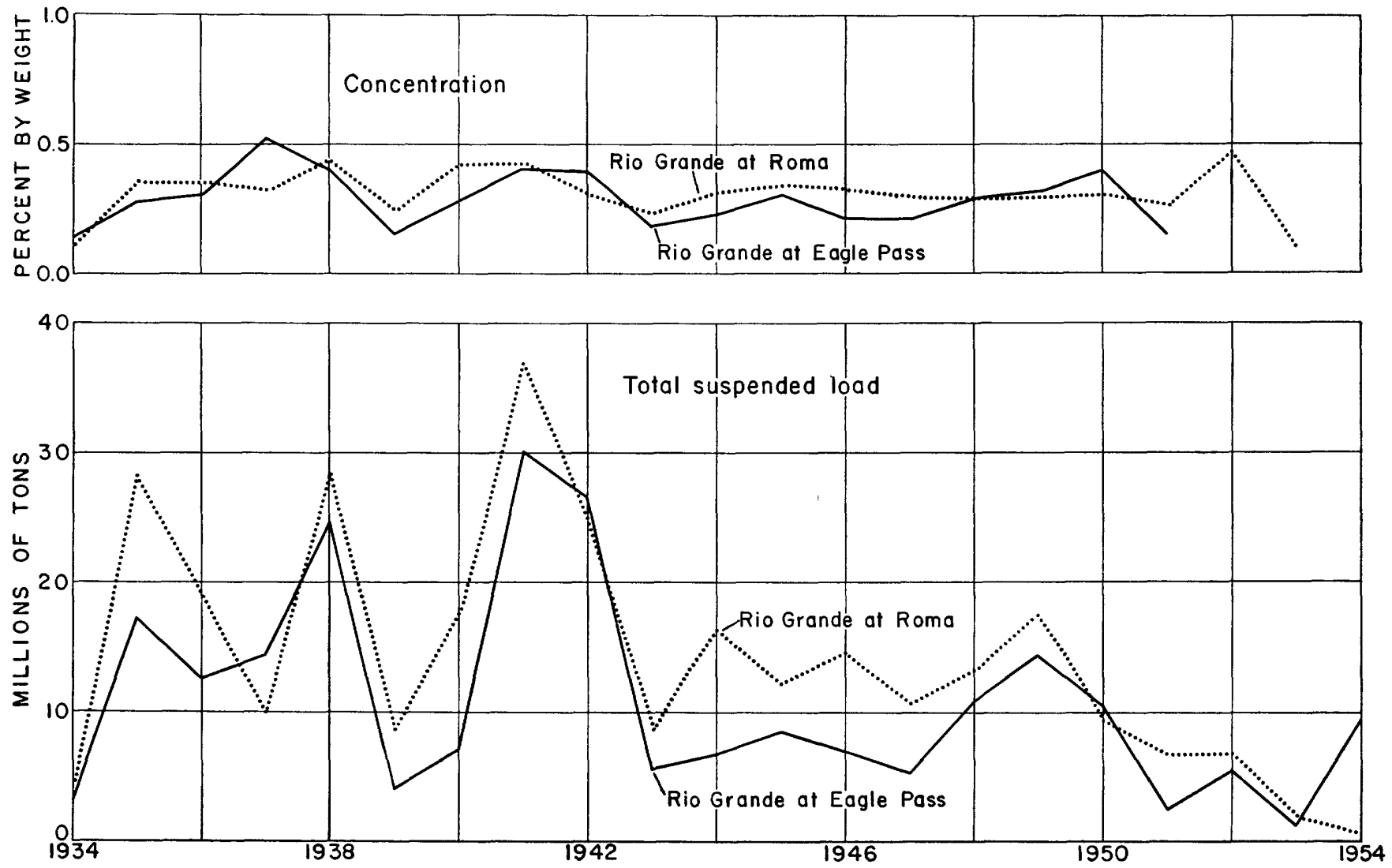

Frodrm 15.-Suspended-sediment load of the lower Rio Grande is greatest in years of greatest runoff, but the annual average concentration ranges between 0.2 and 0.5 percent in both dry years and wet. 
Pecos and upper Rio Grande basins, but the differences result chiefly from different geologic environments. And for an explanation of the geologic environment one must go back 200 million years to the Permian period, during which aridity was so marked that the period might well be labeled the outstanding drought in the geologic history of the Southwest. Sedimentary rocks of Permian age either crop out or underlie alluvium in nearly all the Pecos River basin, and range in thickness from 6,000 to 12,000 feet. The history of the great Permian basin, which extends eastward into central Texas and Oklahoma, has been described by Lang (1937) and King (1942), and depicted on paleogeographic maps by Hills (1942). The significance of the arid climate in the sedimentation is stated by Lang $(1937$, p. 883$)$ :

Climate is one of the factors that control the type of sediment deposited. When anyhdrite or halite beds attain a dominant position in a sediment, even to the exclusion of all others, a hot dry climate is to be inferred and the agent is that of chemical precipitation. Anhydrite, halite, and the redbeds are the most characteristic sediments of the Permian basin.

Thus the legacy of the Permian includes thick layers of evaporites which on the one hand provide most of the Nation's potash and some other salts of economic value, and on the other hand change rainwater into brine; it includes thick and extensive limestones which have been dissolved sufficiently to form productive aquifers in many places and spectacular caverns above the zone of ground-water saturation, and this dissolving action also has contributed to the mineral content of ground water.

Because of this exceptional geologic environment, ground water is of exceptional importance in the Pecos River basin, as pointed out in the report of the Pecos River Joint Investigation (National Resources Planning Board, 1942, p. 82) :

In the basin as a whole, more than half of the irrigated area is supplied from wells and springs. In New Mexico the Pecos Valley contains in the Roswell basin one of the most successful artesian irrigation projects in the world, as well as one of the most extensive developments of nonartesian ground waters in New Mexico and Texas. The lands irrigated from wells represent 56 percent of the irrigated area in the upper and middle basins in New Mexico. In the lower basin in Texas, the acreage irrigated from wells and springs is 41 percent of the irrigated acreage.

It is not alone the available and potential quantity of ground water that emphasizes its importance in the Pecos River basin. Because of the effects of ground-water erosion the surface drainage in much of the area is disintegrated and rainfall and surface water are, to an exceptional extent, diverted underground or evaporated in closed basins. As a consequence, the run-off is relatively low. Underlying much of the area, exposed to and penetrated by circulating ground waters, are exceptionally extensive stratification of salt, anhydrite and limestone. Ground-water erosion of these soluble rocks results in the ground water inflow to the river which in some places contains very large quantities of dissolved salts. This increases substantially the salinity of the river water and renders it less useful for irrigation. In other situations, high ground waters have resulted in seeped lands and extensive growths of native vegetation. The latter in feeding upon ground water remove by transpiration and evaporation substantial quantities that might otherwise be used in beneficial irrigation. Thus, in its effect upon surface water and the available irrigation supplies therefrom, ground water has special significance in the Pecos River basin. And in the study of ground water, the investigation of its sources, occurrence, quality and movement, as well as of its quantity, is of more than ordinary importance.

\section{UPPER AND MIDDLE BASINS, NEW MEXICO}

As summarized in the Pecos River Joint Investigation report (National Resources Planning Board, 1942, p. 27-29) :

From the Sangre de Cristo Range on the north and west where altitudes reach 13,000 feet, the Pecos River and its principal headwaters *** flow as typical mountain streams through narrow valleys and deeply cut gorges. This is characteristic of the main stream for approximately 160 miles from its source to Alamogordo Reservoir near Fort Sumner, and it is this drainage area above Alamogordo Reservoir that comprises the upper basin. It is only in the upper basin that the Pecos River receives a perennial flow derived directly from the snow and precipitation on the mountainous watershed. It is true that perennial flows are derived from similar high mountain sources on the west of the middle basin but such flows occur only on the upper portion of tributary streams and do not reach the river.

The normal flow of the Pecos River and its tributaries in the upper basin is largely used in the irrigation of the lands in the many narrow valleys along the river, and any such flow which may pass Anton Chico sinks into the river bed within a few miles so that the river is dry in the vicinity of Colonias, about 15 miles above the town of Santa Rosa. Near Santa Rosa and below it there are accretions from springs such that the river's normal inflow to Alamogordo Reservoir is as much or more than was the flow near Anton Chico.

* * * as carried on since the days of the Spanish Colonization, irrigation in the narrow valleys of the upper basin is by means of community ditch system. The brush and rock diversion dams for 17 of these ditches are scattered along the river for approximately 100 miles from Pecos Village to Puerto de Luna, 15 miles above Alamogordo Reservoir.

The middle basin comprises that portion of the Pecos River drainage area between Alamogordo Reservoir and the New Mexico-Texas State line. Below Alamogordo Reservoir the deep gorges, narrow valleys and canyon sections characteristic of the upper basin give way to wider valleys between low hills, and these in turn open out into the broad expanse of gently rolling plains which extend southward for 70 miles to the vicinity of Roswell ***. Beginning about 7 miles north of Roswell and extending to the south for 60 miles lies the remarkably even to gently undulating plain which constitutes the lowland portion of the Roswell artesian basin. The Pecos River flows through this basin along the east edge of the 
lowlands, and the area of artesian flow, averaging 7 miles in width, roughly parallels the river on the west. McMillan Reservoir, near the mouth of Seven Rivers, is at the lower end of the artesian basin. A few miles below it the hills close in and for some 12 miles the river flows through an open canyon or narrows section which terminates at Avalon Reservoir, 3 miles north of Carlsbad. Opening out below Avalon Reservoir, the somewhat narrow valley within which lie the lands of the Carlsbad project extends for 20 miles to another narrows section which begins below Malaga and the mouth of Black River. Throughout this valley the channel of the Pecos River is along its eastern edge. Below Malaga the narrows section extends about 15 miles to the Red Bluff Reservoir.

The middle basin is flanked on the west by a chain of mountain ranges comprising, from north to south, the Jicarilla, Capitan, White, Sacramento, and Guadalupe Mountains. Crest altitudes of these mountains range from more than 12,000 feet on the north to around 9,000 feet on the south. All of the middle basin tributaries of the Pecos River of any importance originate on the eastern slope of this chain of mountains. Although these principal western tributaries are perennial streams in their upper courses, seepage losses and diversions for irrigation in their mountain and foothill valleys are such that normally no flow reaches the Pecos River valley. Near the river the tributary channels may intersect the water table and thence carry a perennial spring-fed flow to the river.

Under conditions of normal flow (excluding flood flows resulting from torrential storms), most of the water which passes Fort Sumner is lost by evaporation and seepage and the river becomes practically a dry stream down to the mouth of Salt Creek. From this point to McMillan Reservoir accretions from groundwater and return from irrigation reestablish the flow and furnish the normal inflow to the reservoir. A few miles below McMillan Reservoir the flow is again reestablished by a series of large springs in the river bed and this makes up the normal inflow to Avalon Reservoir. Once again, below Avalon Reservoir, the flow is reestablished by springs near Carlsbad and by the return from irrigation in the Carlsbad area in part entering through Black River, and this becomes the normal inflow to Red Bluff Reservoir.

It is characteristic of the Pecos River in the middle and lower basins and to considerable degree in the upper basin, that this normal basic flow which is lost and reestablished many times over, is a somewhat minor percentage of the average annual run-off. Contributing in greater measure to that average is the flood run-off resulting from the erratic and torrential storms which usually occur in the period from March to November. And since only the normal basic flow is dependable for irrigation by direct diversion, storage to capture and make available the flood waters has been and is a particularly essential requisite to any major development of irrigation from stream flow in the Pecos River valleys.

The major trends in runoff in the upper and middle basins are shown in figure 16 . The annual outflow from the upper basin during drought years (1908-13, 1927-36, and 1951-56) has generally been within the range of 100,000 to 200,000 acre-feet. Although the outflow was less during droughts than during the intervening wetter years, there is no indication of progressive diminution. The annual outflow from the upper basin has been within 20 percent of the median in more than half the years of record, reflecting the stability in pattern of use (the irrigated acreage and irrigation practice have changed little in the past half century) as well as the natural stability provided by ground-water storage. However, the water production of the middle basin, as computed by the difference in runoff measured at the Alamogordo and Red Bluff gaging stations, has trended generally downward for several decades. Although the middle basin contributed about half as much to the river as the upper basin until 1934, it has contributed substantially to the river in only 5 of the 23 years since 1934 . In the decade 1946-55, the outflow from the middle basin was 23 percent less than the quantity entering the middle basin from the upper basin.

A cumulative mass diagram of precipitation and runoff in the middle basin (fig. 17) shows that the contributions from the middle basin to the Pecos River per unit of precipitation have decreased progressively since 1919, and have been negative (that is, the Pecos has lost water within the middle basin) since 1945. This decrease may be ascribed in part to drought, for in the 40 years 1917-57 there was a net deficiency of precipitation equivalent to 4 times the annual average and it is a general rule that abundant precipitation causes not only higher runoff but a higher proportion of runoff. However, there were droughts also in the early part of the record. To discriminate the effects of drought from other factors that may affect river flow, it is necessary to consider in some detail the hydrology of the Roswell basin and the Carlsbad area, which historically have been the principal contributors to the Pecos River in the middle basin.

\section{ROSWELL BASIN}

Roswell, N. Mex., is famous for its early and intensive development of ground water, and for stimulating efforts at regulation of the development and use of that water. It had flowing wells for domestic use in 1891 and for irrigation in 1903. Declining artesian pressure during the early stages of development provided impetus for one of the first laws in the country regulating use of artesian wells-passed by the Territorial Legislature in 1905 before New Mexico became a State. In the 7 years $1905-11$ about 700 large ( 6 to $10 \mathrm{inch}$ ) wells were drilled for irrigation, and the average rate of decline in artesian head was greater during those years than in any subsequent year. Yet the most productive flowing well in the area (and reportedly in the world at that time) was drilled in March 1926, when it was estimated to have flowed 6,000 gpm, or $8.6 \mathrm{mgd}$. The Roswell artesian 


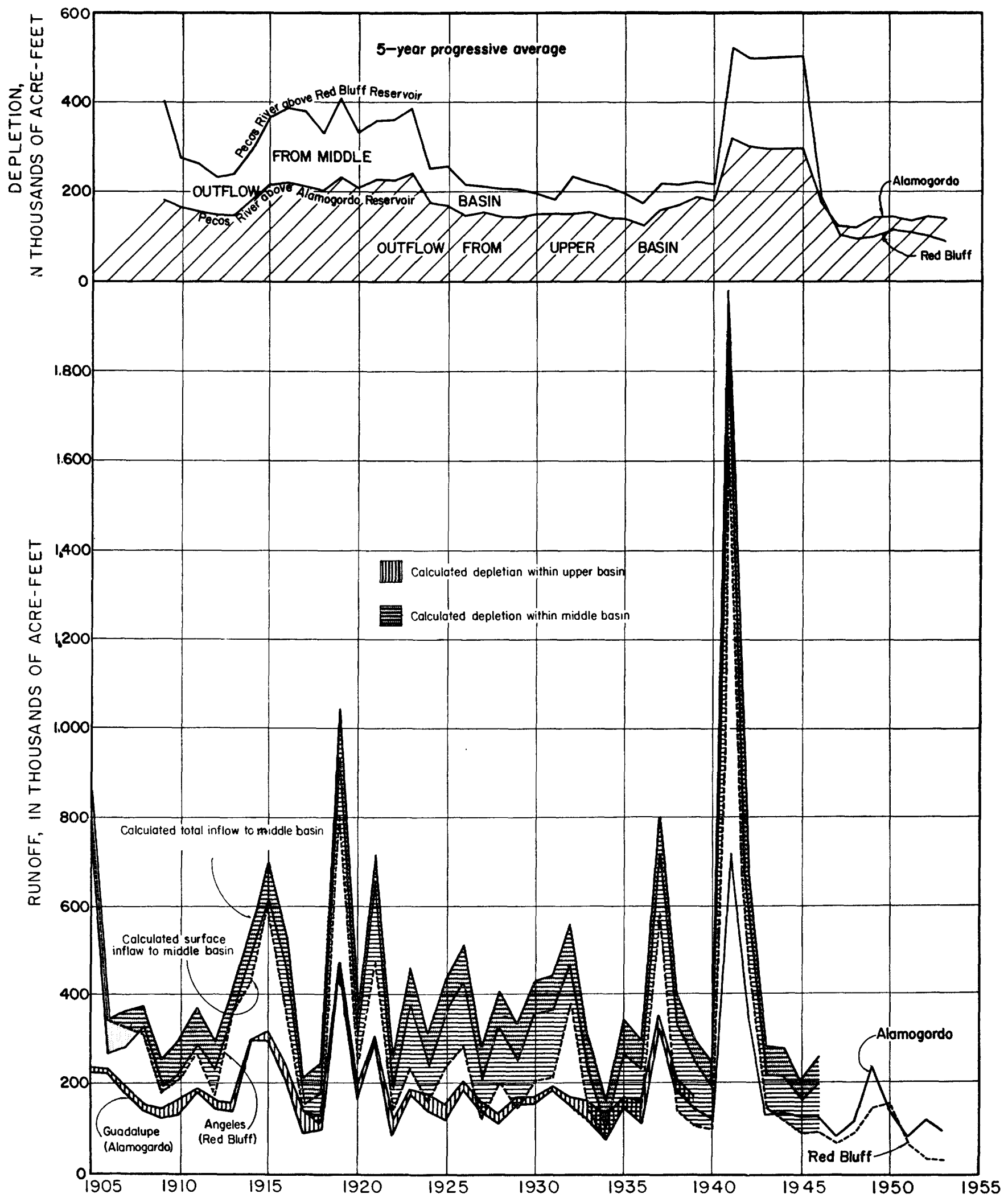

Figure 16.-Measured runoff, 1905-53, and depletion of Pecos River between Alamogordo and Red Bluff Reservolrs, 1905-46, as calculated by Pecos River Compact Commission (U.S. Congress, 1949). 


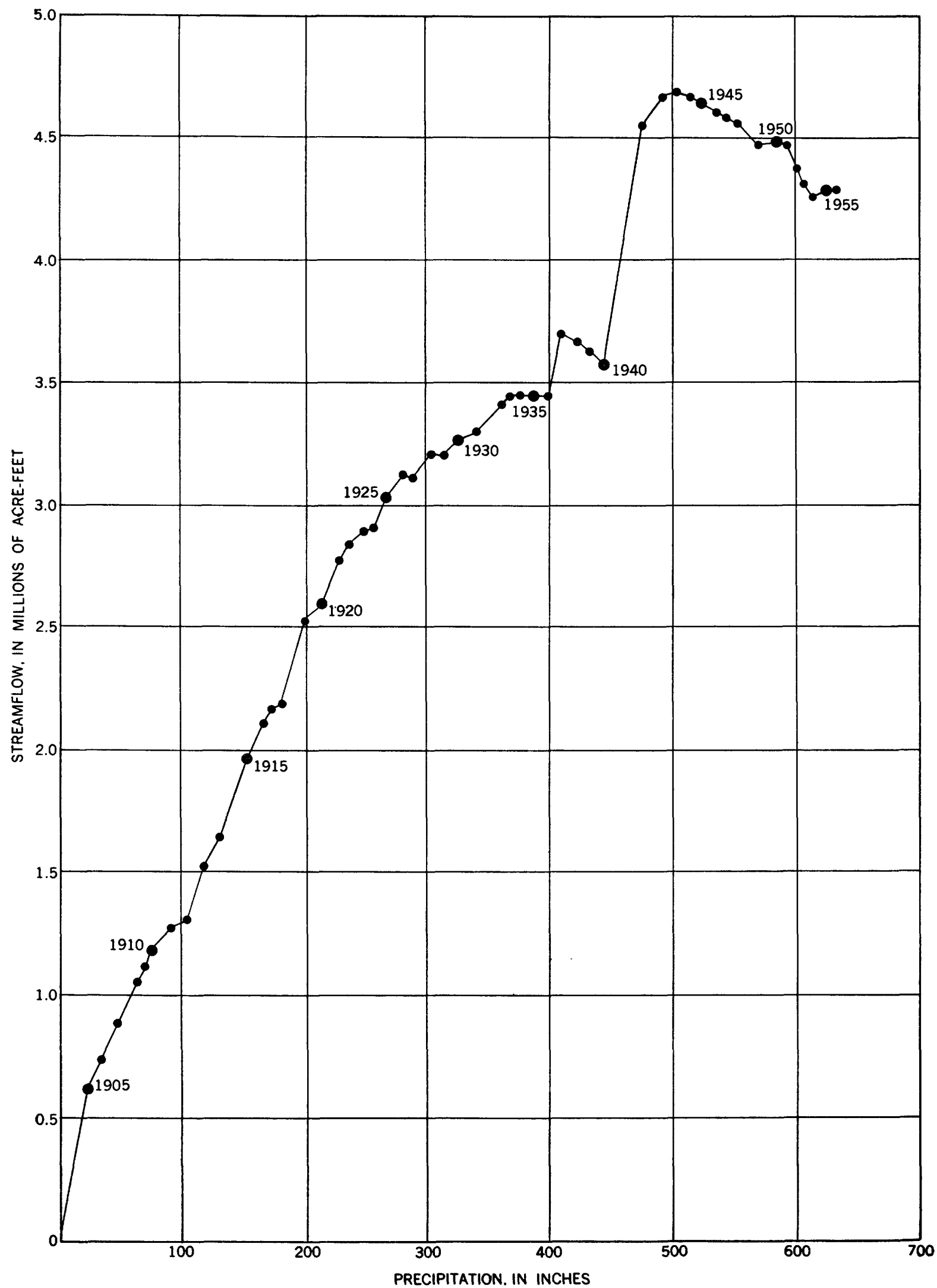

Figdre 17. - Cumulative mass diagram of precipitation compared with water production in middle basin of Pecos River, $1905-56$. 
ground-water basin was also one of the first in the country to be subjected to detailed quantitative investigation (Fiedler and Nye, 1933). The demand for protection of its water resources was the chief reason for passage of New Mexico's ground-water law in 1931, which provides the basis for regulating development and use of ground water throughout the State. Because of the special attention given to the Roswell basin over the years, hydrologic data are available to show not only any observable effects of natural climatic fluctuations, but also the effects of use under controlled conditions, over a period of more than a quarter of a century.

The limiting hydrologic features of the Roswell basin are (1) on the west, the crest of the Sacramento and Guadalupe Mountains, which reaches altitudes that exceed 9,000 feet in many places and thus constitutes the best rain-catcher in the southeast quarter of New Mexico; (2) 80 miles to the east and more than a mile lower, the Pecos River, which carries the outflow from its upper basin plus any increment that is added as it traverses the Roswell area; (3) to the south, the resistant limestone of the Seven Rivers gypsiferous member of Chalk Bluff formation, which forms a narrows along the Pecos River at McMillan Dam and the Seven Rivers cuesta, 200 to 300 feet high, west of the dam; and (4) to the north, an inconspicuous ground-water divide about 90 miles north of Roswell. Thus the Roswell hydrologic unit is an eastward-sloping area that extends nearly 150 miles north-south and is bounded by a mountain crest on the west and a river on the east.

The broad pattern of the hydrologic cycle in the Roswell basin includes inflow (by precipitation) that is greatest at the west boundary and decreases eastward, movement eastward of this water both underground and in ephemeral streams with some losses by evapotranspiration, and eventual disposal to the Pecos. The eastward movement of water, past and present, has created many complex details in this simple pattern. As pointed out by Fiedler and Nye (1933, p. 19, 98-109) the water flowing in Salt Creek, Rio Hondo, Rio Felix, Rio Penasco, and Seven Rivers has formed an "alluvial basin" extending along the Pecos River for about 70 miles, with width ranging from 10 to 25 miles. Earlier in geologic history the runoff from these mountains may have been a major factor in the southward diversion of the Pecos River from a former course across the Llano Estacado, and in the isolation of the High Plains (Thomas and others, 1963a). At any rate, the alluvial plains and terraces built by these eastward-flowing streams are now the areas most desirable for agricultural use, and include practically all the area presently under irrigation. The unconsolidated sediments of the "alluvial basin" constitute one of the important aquifers in the Roswell area. These sediments are probably less than 200 feet thick in most places, but in some localities they exceed 300 feet; wells obtain water from gravel and sand in this alluvium for irrigation of about 50,000 to 55,000 acres of land.

The shallow alluvial aquifer is not the major source of water withdrawn by wells, however, nor is it the basic hydrologic unit in the Roswell area. That honor goes to the San Andres limestone of Permian age, which crops out in a broad band along the flanks of the Sacramento Mountains, and underlies all the Roswell basin east of that outcrop. This limestone, more than 1,000 feet thick, is the artesian aquifer in the Roswell area and it produces water for irrigation of 70,000 to 75,000 acres. In the irrigated area the top of the San Andres ranges from 250 to 1,200 feet below the surface; it is covered by red beds, sandstone, shale and gypsum of the Chalk Bluff formation, and by the shallow alluvial aquifer.

The present characteristics of the artesian aquifer doubtless reflect the varying solubility of the limestone from place to place, and also the varying rates of ground-water circulation from place to place. Pumping tests indicate very high transmissibility of the aquifer near Berrendo Spring, North Spring, and South Spring, which now yield little water but were the largest natural outlets from the artesian basin. In the irrigated area the upper part of the San Andres is the most permeable part, but in its outcrop area, where the water table is far below the surface, the most permeable zones may be near the base of the formation, or even in the underlying Yeso formation. The San Andres occurs east of the Pecos also, with eastward dip and therefore at increasing depth, but wells tapping it east of the Pecos have generally brought forth brines; it is likely that even prior to development the fresh-water flow continued in the aquifer only as far as the east edge of the Pecos River valley. Thus, so far as usable water is concerned, the east boundary of the artesian basin is only a short distance east of the river.

A preliminary quantitative study of the Roswell ground-water reservoir was made by Hantush (1955) based on previous studies of the geology and groundwater conditions in the basin, on data accumulated during the development and operation of the basin, and on several drawdown and recovery tests at selected wells. His analysis includes the alluvium of the alluvial basin, the San Andres limestone, the overlying Chalk Bluff formation, and the underlying Yeso 
formation, because they are all elements in a relatively continuous hydraulic system from the west edge of their outcrop areas to at least as far downdip as they contain usable water.

A prime unit in this hydraulic system is the part of the San Andres that is covered by the Chalk Bluff formation and the alluvial aquifer and occupies a belt averaging 20 miles wide west of the Pecos River. In the eastern two-thirds of this belt the aquifer is continuously full of water under pressure, and there is upward leakage through the Chalk Bluff and into the alluvial aquifer, and probably also directly into the Pecos River. Farther west and up the slope of the Sacramento Mountains, where the San Andres limestone crops out on the upland surface, the aquifer is recharged by absorption of precipitation and of runoff over an aggregate area of more than 5,000 square miles. An increase in storage in this recharge area increases the head and therefore the upward leakage in the artesian portion.

Hydrographs of artesian observation wells indicate that the recharge from exceptional precipitation (such as that in 1941) may continue for at least 3 years. Accordingly, Hantush has developed an empirical index of precipitation (one-half the average at Roswell and Artesia in the current year plus one-third of the average in the preceding year plus one-sixth of the average in the second prior year), which he has compared with pumpage during two years (1928 and 1944) when the flow in the artesian reservoir was in dynamic equilibrium, and when therefore recharge was equal to discharge. His computations indicate that in the period 1941-53 the annual recharge to the San Andres ranged from 150,000 acre-feet in 1953 to 490,000 acre-feet in 1941, and averaged about 257,000 acre-feet; in a succession of years when the average of the precipitation at Roswell and Artesia is 10 inches, the recharge to the artesian reservoir would average about 210,000 acre-feet a year.

Under natural conditions the artesian aquifer discharged by upward leakage to the Chalk Bluff formation and the shallow aquifer, and the annual leakage would vary from year to year, depending chiefly upon the artesian head, which in turn reflected the changes in storage in the recharge area. Hantush's computations indicate that upward leakage from the artesian aquifer was about 80,000 acre-feet in 1928 and 1944, when the flow in the reservoir was at equilibrium. By comparison, Fiedler and Nye (1933) estimated the upward leakage to be 77,000 acre-feet in 1927. Flowing and pumped wells have modified the average head differential between artesian and shallow aquifers, and produced great variations from place to place and from time to time. Available data are not sufficient to permit determination of the amount of leakage each year, but Hantush estimates indicate an average annual upward leakage of 45,000 acre-feet in 1945-49, and 11,000 acre-feet in 1950-52; in 1953 there was net downward leakage of 42,000 acre-feet.

The uppermost graph of figure 18 shows the annual recharge as computed by Hantush from the RoswellArtesia index of precipitation-greater than the longterm average of 210,000 acre-feet in each year of the period 1936-44, but less than that average in all subsequent years except 1949-51. The estimated withdrawal from artesian wells is indicated by ruled pattern below this graph, forming a band that is narrowest in 1941 (when withdrawals were less than 100,000 acre-feet) and becomes progressively wider until 1953, when withdrawals from artesian wells exceeded 300,000 acre-feet and were thus about twice the computed recharge in that year. In 1947 and 1948 and in every year since 1950 the withdrawals have exceeded the calculated recharge. The incomplete data concerning leakage (Hantush, 1955, p. 61), also graphed in figure 18, show the reduction in upward leakage since 1944, with a reversal in direction of leakage by 1953.

Under natural conditions the largest item in the recharge to the shallow alluvial aquifer was the leakage from the artesian aquifer, averaging 80,000 acre-feet annually. To this should be added the recharge from local precipitation, which was estimated by Morgan (1938) to average 30,000 acre-feet a year, but which may well fluctuate in consonance with the Roswell-Artesia precipitation. Also, some of the water applied for irrigation returns to the shallow reservoir, whether it is pumped from the artesian or the alluvial aquifer or diverted from the Pecos River; Hantush estimates the amount of this "recharge" to be 20 percent of the total pumpage from both reservoirs. The estimated annual recharge to the shallow reservoir by each of these three means is shown in figure 18. Pumpage from the shallow reservoir is seen to have been greater than the total recharge by leakage, precipitation, and irrigation return in 1947 and 1948, and in every year since 1950 .

Although pumping has replaced seepage to the Pecos River as the principal means of ground-water discharge, seepage has not been eliminated even in recent years of heavy pumping. The gain in flow of the Pecos River between Acme and Artesia, as calculated by Flook (1958), is shown by the lowest graph of figure 18. Shallow-water levels in areas along the Pecos River remain higher than the river at least during the winter, and the water-table gradient is 


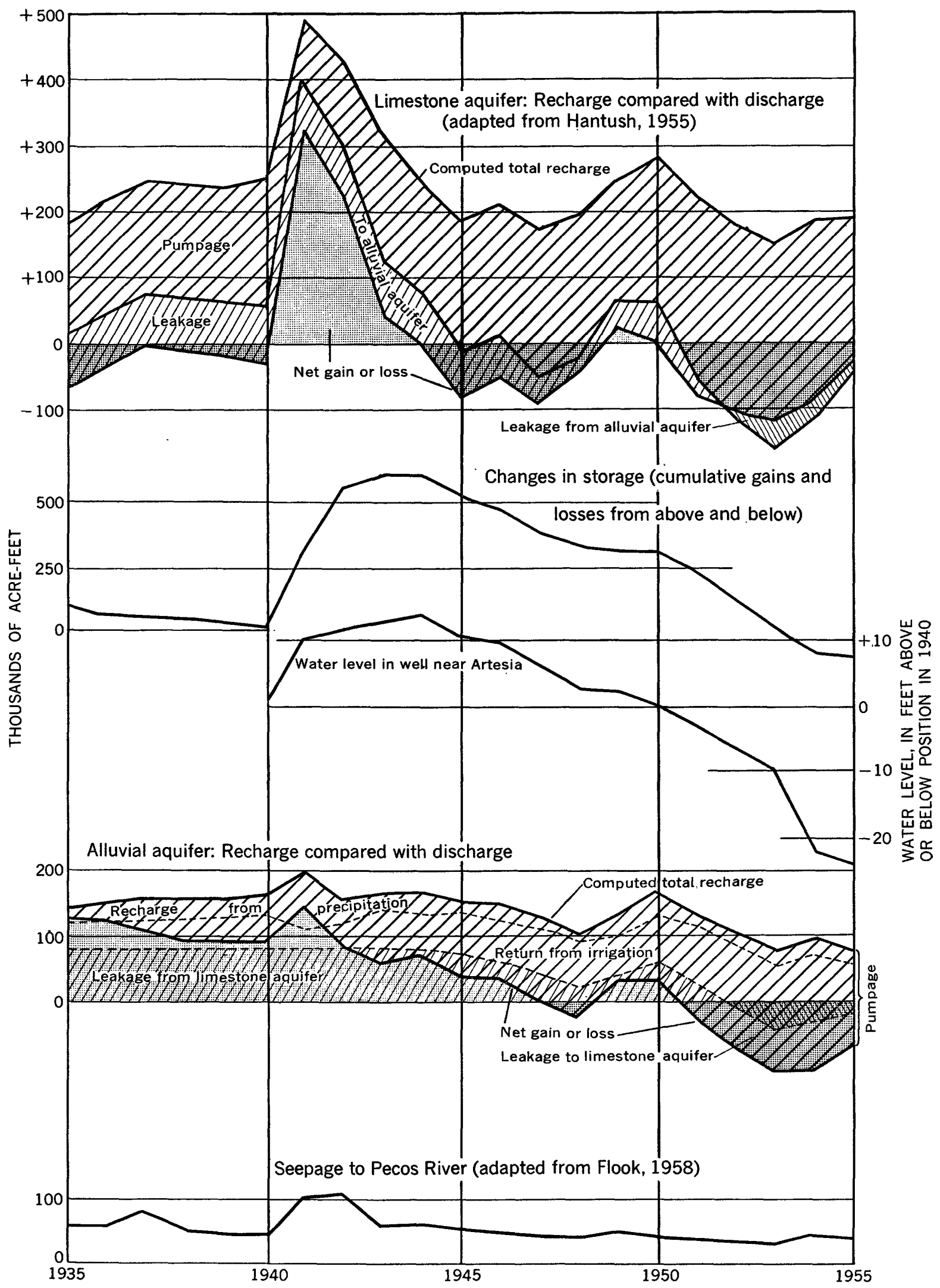

FIGURE 18.-Ground-water reservoirs of Roswell basin showing trends in recharge, discharge, and storage, 1935-55. 
still toward the river channel; also, the head in the underlying artesian aquifer is at all times higher than river level. Nevertheless, seepage to the river probably is reduced during the growing season because of pumping and because of evapotranspiration. Pumping has also depleted the storage in the shallow aquifer, as confirmed by the progressive decline of water level in representative shallow wells.

All the described items of recharge to and discharge from the entire hydraulic system have been added algebraically and accumulated for the period 1936-55, to produce the middle graph of figure 18. This graph, representing the inferred changes in storage from year to year in the reservoir system, follows trends similar to those shown by water levels in representative wells. However, there is indication that this hydrologic budget may be on the optimistic side with respect to changes in storage, for it suggests that the quantity of water in storage as of 1952 was about as great as that in 1940, whereas in most observation wells water levels in 1952 were substantially lower than in 1940.

From his analysis, Hantush concluded that the average annual recharge to the entire reservoir (from precipitation upon shallow alluvium plus precipitation upon the San Andres recharge area) totals about 240,000 acre-feet. This comes very close to the average recharge of 235,000 acre-feet as inferred by Fiedler and Nye (1933, p. 252). For Hantush's analysis there were an additional 27 years of hydrologic records; nevertheless, he points out that his analysis provides only qualified answers to several of the problems of the area, and recognizes that many refinements would be possible with additional basic data.

The close check between the average recharge as computed by Fiedler and Nye in 1927 and by Hantush in 1955 indicates that the climatic fluctuations in the intervening 27 years have not been such as to change our concept of the "average" conditions. Within those 27 years there was abundant recharge resulting from precipitation in 1941, which was the year of maximum precipitation in 80 years of record; and there was deficient recharge during the Southwest drought, which included 8 of the 16 driest years in the 80-year period of record. It is possible that exceptional precipitation in the future may modify the long-term average somewhat, but the record is long enough that large changes are unlikely. Similarly, additional basic data may lead to some revision of the precipitation-recharge relation, but those revisions are not likely to make large changes in the estimated average annual recharge of 240,000 acrefeet. In recent years the total pumpage has been as much as 400,000 acre-feet annually; even if 25 percent of the pumped water returns to the reservoir, the recharge is being exceeded by pumpage at a rate exceeding 50,000 acre-feet a year.

Two distinctive effects of the depletion of groundwater storage are illustrated by the maps of figure 19 . The decline of water levels in shallow wells south of Roswell, reaching a maximum of more than 50 feet near Hagerman, indicates that pumping in the 15 years 1940-54 caused a significant reduction of storage in the shallow aquifer. In the artesian aquifer, which remains saturated at all times, most of the water pumped must be replaced by lateral movement within the aquifer. There is evidence that some of the water pulled into the pumping area has come from the saline part of the aquifer east of the Pecos River, where the chloride content increases from less than $300 \mathrm{ppm}$ in Roswell to more than $4,000 \mathrm{ppm} 4$ miles to the east. In an extensive area 2 to 4 miles east of Roswell the salinity of pumped water has increased significantly in recent years; in the section of most concentrated draft about 2 miles east of Roswell, the chloride increased by 100 to $200 \mathrm{ppm}$ in 2 years, as shown also in figure 19. The changes depicted in figure 19 are unrelated to drought, except as drought may have influenced the rate of pumping from wells.

\section{CARLSBAD AREA}

By L. J. BJORKLUND

The Carlsbad area, downstream from the Roswell basin, is a second major area of development in the middle basin of the Pecos River (Bjorklund and Motts, 1959). As in the Roswell basin, the principal use of water in the Carlsbad area is that for irrigation, but there is the difference that the Carlsbad area has always obtained nearly all its irrigation water directly or indirectly from the Pecos River. If the water diverted from the stream channel or released from surface reservoirs is labeled surface water, and that taken from wells is called ground water, then the Carlsbad area was irrigated almost entirely by surface water before 1945 , and predominantly by surface water in the succeeding decade, except in 1953 and 1954 when the water pumped from wells constituted more than 50 percent of the total water applied for irrigation. But the usual distinctions between surface water and ground water are especially difficult to maintain in the Carlsbad area. Much of the water stored in Lake McMillan and Lake Avalon is lost by underground leakage and becomes ground water, only to reappear farther downstream at springs, which discharge into the river. On the other hand, most of the water pumped from wells has come from the river by seepage either from the channel or from irrigation canals or irrigated lands. 

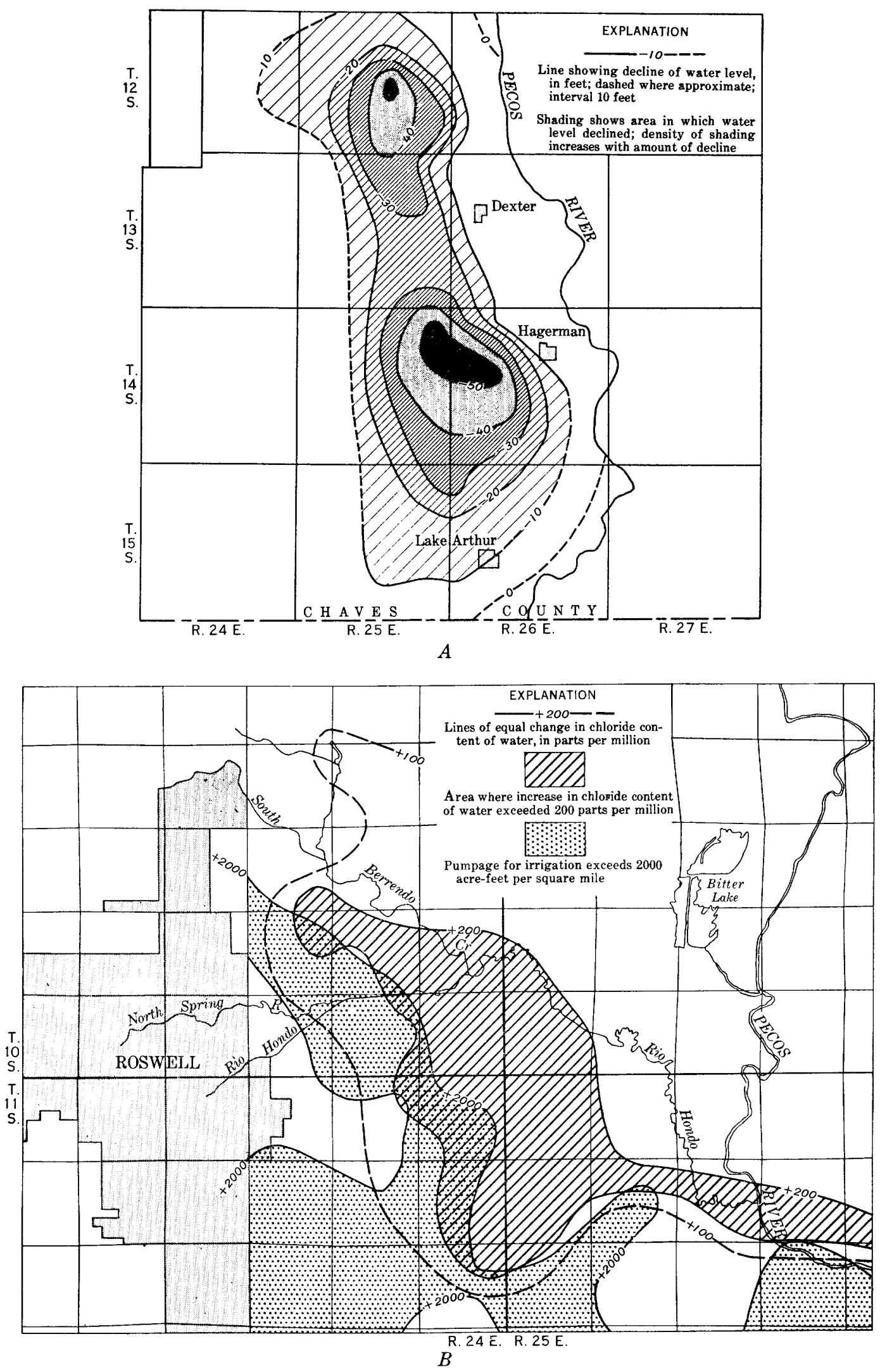

Figurw 19.-Some effects of depletion of ground water reservoir in Roswell basin. $A$, Water-table decline near Hagerman, January 1940-January 1955; $B$, Increase of chloride in artesian water east of Roswell, 1953-55. 
The Carlsbad irrigation project was initiated in 1888 by private interests and was taken over by the U.S. Reclamation Service in 1906. According to the court decree of Pecos River adjudication of 1933, the project has rights throughout each year to the use of $1,000 \mathrm{cfs}$ from the Pecos River with priority date of 1888 or earlier, plus storage rights of 7,000 acre-feet in Avalon Reservoir dating from 1889 and storage rights of 90,000 acre-feet in McMillan Reservoir dating from 1893; and in addition the right with priority date of 1906 to impound as much as 300,000 acre-feet of water. As of 1956 the surface reservoir capacity available to the Carlsbad project included 38,600 acre-feet in Lake McMillan (largely ineffective because of leakage), 6,200 acre-feet in Lake Avalon, and 129,000 acre-feet in Alamogordo Reservoir, which was completed in 1937.

With respect to ground water, the Carlsbad area is like the Roswell basin in being dependent upon both a limestone aquifer and an alluvial aquifer, and it is like the Roswell basin in that the limestone aquifer under natural conditions was a contributor to the flow of the Pecos River. The principal limestone aquifer is the Capitan limestone, a massive reef limestone of Permian age, but somewhat younger than the San Andres limestone and produced in shallower water in the Permian basin. The Capitan limestone is the favored source of municipal and industrial supplies in the city of Carlsbad and its environs, but wells in the limestone produce less than one-fourth of the total water pumped from wells in the Carlsbad area.

The shallow alluvial aquifer along the Pecos River is the principal source of water pumped for irrigation. The greatest saturated thickness of alluvium-more than 150 feet-is near the river along old drainage courses, and this is where the most productive wells are located. Under natural conditions the alluvial aquifer was recharged by precipitation and by flood runoff in tributaries to the Pecos, and there were numerous springs and seeps along and near the stream channels. For more than half a century, however, an important source of water in the alluvium has been seepage of water diverted from the Pecos River and applied for irrigation. Water levels in the alluvium in the Carlsbad area probably were highest in 1916, when ground-water levels rose nearly to the land surface. The land had been irrigated heavily by water diverted from the Pecos River during the preceding 10 years and a large quantity of water had seeped from irrigation systems to the ground-water reservoir. A drainage system completed in 1919 ended the era of waterlogging, but the water table probably remained fairly close to the land surface until the de- velopment of irrigation wells, in 1946. The Carlsbad ground-water basin was declared by the State Engineer in 1947 and the area was extended in 1952, to limit the construction of irrigation wells and protect the ground-water resources from overdevelopment.

The effects of drought upon the Carlsbad area are shown clearly in the water supplies for the crops grown on lands of the Carlsbad project, because these are dependent in large part upon the Pecos River. In 65 years of record at Carlsbad, the average annual precipitation has been about 13 inches, but it was less than that average in 11 of the years 1943-56, and less than 8 inches in 6 of those 14 years (fig. 20). Although two-thirds of the annual precipitation ordinarily falls during the growing season, irrigation has been essential for successful growing of crops. In a few years the amount of diversion is an indication of the fluctuating need for water, as for example in the wet year 1941, when the annual precipitation was nearly 34 inches of which 27 fell during the growing season, so that less water was used for irrigation than at any time in the preceding quarter of a century. In many years the diversions appear to be an indication of the availability of surface water, as for example in the dry years 1917, 1934, 1947, and 1953. Generally the fluctuations in diversions to the project reflect those in precipitation with a 1-year lag, indicating some regulation by storage either in groundwater or surface reservoirs; carryover from wet years worked to the benefit of the project especially in such individual dry years as 1924, 1927, and 1955. There has been a general downward trend in surface-water diversions since 1920, a trend that has not changed materially during the recent extended drought period. There is no clear evidence of a similar long-term downward trend in precipitation at Carlsbad.

After 1945 the development of irrigation wells tapping the alluvial aquifer progressed so rapidly that in the years 1950-54 the total water applied annually for irrigation was as great as the maximum during the decade preceding the drought, and in 1955 was the greatest in history. In part this ground-water development provided supplemental supplies to lands previously irrigated by surface water, and in part it permitted an increase in irrigated area. The irrigated area in the Carlsbad project had remained fairly stable at about 24,000 acres from 1921 to 1936, the water use fluctuating from year to year according to the supply, except in dry 1934 when the irrigated acreage was reduced. In the latter part of the Depression, and in spite of the completion of Alamogordo Reservoir, the irrigated area dropped to 20,000 acres, where it remained throughout World War II. Pumping from 
irrigation wells enabled expansion of the irrigated area to 30,000 acres by 1948 , and at least this much area has been irrigated in each subsequent year, in spite of several successive very dry years beginning in 1951.

One effect of pumping from the alluvial aquifer has been to create a pronounced cone of depression in an area south of the city of Carlsbad and west of the area irrigated by surface water. The center of this cone was more than 60 feet deep after 8 years (1947-54) of pumping. The hydrograph of well 22.26.36.111a (fig. 20) shows the general downward trend of water levels in wells in this area beginning in 1947, with a slight interruption during the relatively wet years 1949 and 1950. In wells tapping the alluvial aquifer near the Pecos River or in areas receiving irrigation water from the river, there has been less lowering of water levels because of recharge from that irrigation water, but that recharge necessarily causes some depletion in flow of the river downstream from the Carlsbad area.

Although the depletion of ground-water storage and the reduction of river flow downstream are definitely traceable to pumping from wells during the

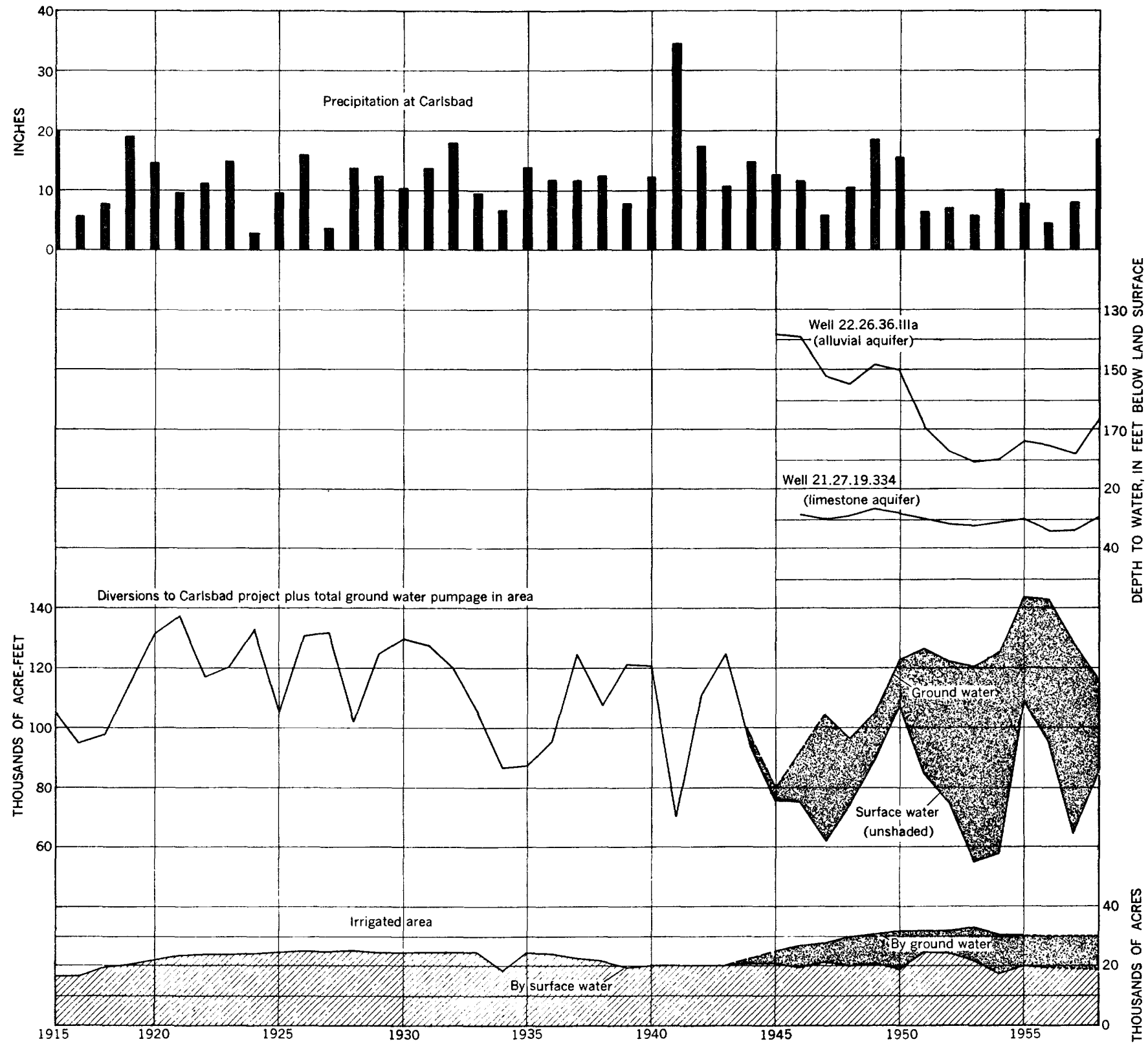

FIGURE 20.-Precipitation at Carlsbad, irrigated acreage, surface-water diversions, pumpage from wells, and fluctuations of water levels in two wells in Carlsbad area, 1915-58. 
drought period, it is difficult to assess the proportion attributable to drought, because part of the water pumped was for use on new land (unirrigated before the drought), and part was a substitute for failing surface-water supplies. Although this failure was especially marked in such dry years as 1946-48 and 1951-54, these years were at the end of a much longer period of downward trend in stream supplies, a trend that probably is correlative with increasing development and use of water upstream from the Carlsbad area.

The aquifer in the Capitan limestone, recharged chiefly by precipitation upon the outcrop area, constitutes an underground tributary to the Pecos River, as shown by the gentle eastward gradient in head. Some of the water in the aquifer may be discharged into the alluvial aquifer near Carlsbad, but a major point of natural discharge is the Carlsbad Springs, which discharge into the Pecos River. The Carlsbad Springs also discharge Pecos River water that has leaked into the limestone from Lake Avalon and from canals that carry water to the Carlsbad project; the quantities of leakage can be estimated with fair reliability and the contribution from the limestone can be computed by difference. As shown by figure 21, the leakage from Lake Avalon reached a peak of 40 cfs or more each winter until the drought year 1952 . The discharge of Carlsbad Springs, which includes this leakage, rose above $100 \mathrm{cfs}$ in 1941-42, and declined to minimums less than $30 \mathrm{cfs}$ in 1953, 1954 and 1956. Some increases in discharge from the springs are directly correlated with heavy rains (Bjorklund and Motts, 1959, p. 183).

Part of the decline in Carlsbad Springs during the drought years $1950-54$ is correlative with the reduction in leakage from Lake Avalon, and part is attributable to diversion from the limestone aquifer by pumping from wells. The graph of the total of spring discharge plus pumpage (upper line of fig. 21) shows the fluctuation in yield from the limestone reservoir in response to climatic fluctuations; increasing with recharge during wet years 1941-42 and 1948-49, and decreasing subsequently to a base that appears to average about $60 \mathrm{cfs}$.

Pumping from wells in the limestone aquifer has not caused a marked decline in water levels, and the principal effect of pumping has been reduction in spring discharge. In some months in 1953 and 1954 the discharge from Carlsbad Springs was less than the computed leakage from Lake Avalon. In those months the wells were drawing more than the local yield of the aquifer, and it is to be expected that some of the water from Lake Avalon would be di-

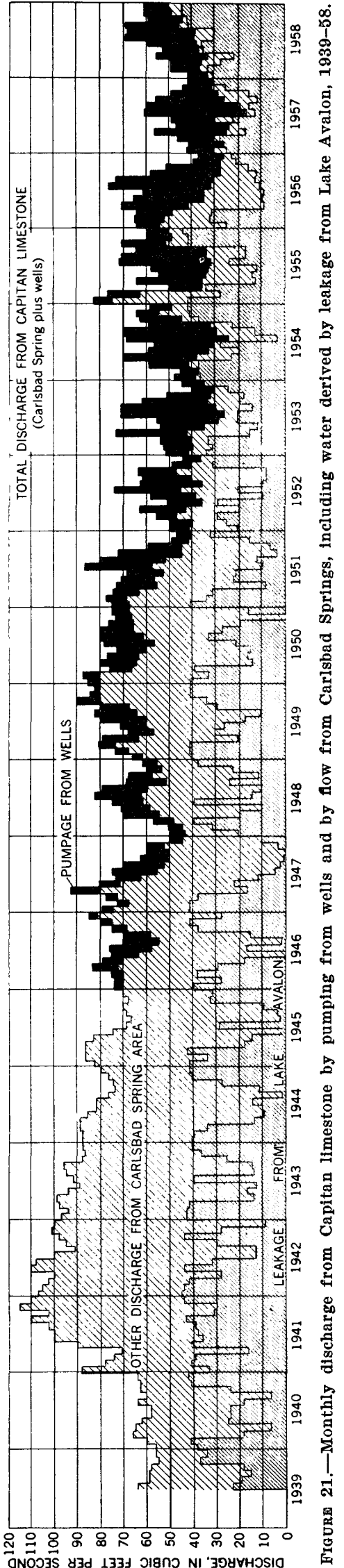


verted toward the wells. Such diversion can be quickly recognized at the wells, because the Lake Avalon water is usually of inferior quality.

\section{LOWER BASIN, TEXAS}

Quoting again the report of Pecos River Joint Investigation (National Resources Planning Board, 1942, p. 30) :

The lower basin comprises that portion of the Pecos River drainage area between the New Mexico-Texas State line and the mouth of the river. It includes, therefore, all of the Texas portion of the Pecos basin.

* * * Below Red Bluff Reservoir the low hills recede on either side, and the river enters and meanders through a very broad expanse of gently rolling plains which extend to within about 100 miles of the river's mouth. The area under the Red Bluff Water Power Control District occupies the narrow flood plain and lower lands along both sides of the river beginning at Arno, 40 river-miles below Red Bluff Reservoir, and extending approximately 90 miles (165 river-miles) to Girvin. All of the Texas lands that are irrigated from the Pecos River are included in this area. Below Girvin the topography becomes rougher and beginning near Sheffield, 50 miles below Girvin, the river valley becomes very narrow, and steep rocky bluffs hem the stream on both sides. This leads rapidly to an ever-deepening and rugged canyon section which extends to the river's confluence with Rio Grande. At its lower end this canyon is more than 300 feet deep $* * *$ the character of the lands and topography along the river are such that there is and has been practically no irrigation development. Therefore, with respect to water supply and the problems thereof, this portion of the Pecos basin is of no concern in the present investigation. From Girvin to the mouth of the river there are substantial accretions, largely from springs, some of which are along tributaries.

Several miles southwest of the main river valley, near the towns of Balmorhea and Fort Stockton, some lands within the Pecos River basin are irrigated by spring and tributary flow from a predominantly limestone terrane, but this flow does not reach the Pecos River except under extreme flood conditions. The town of Alpine also is in an area which contributes water to the Pecos only after torrential rainstorms; the town obtains its meager water supplies from wells distributed over a volcanic terrane.

\section{RED BLUFF WATER POWER CONTROL DISTRICT}

According to estimates made during the Pecos River Joint Investigation (National Resources Planning Board, 1942, p. 76) the tributary inflow to the Pecos between Red Bluff Reservoir and Girvin averages about 60,000 acre-feet a year, and includes flood inflow and ground-water inflow in approximately equal proportions. Even though the flood inflows may not be usable directly for irrigation, they may recharge the ground water in the alluvium, which is tapped by several wells to supplement the surface supplies, and thus a substantial proportion of this tributary inflow may be salvaged for irrigation. But the total side inflow is only one-fifth of the average measured flow of the Pecos at the State line in the period 1905-46. Thus irrigators in the Red Bluff district depend primarily upon water stored in and released from Red Bluff Reservoir.

Red Bluff Reservoir was filled nearly to capacity by inflow during 1937, and was at capacity during several months in 1941 and 1942 (fig. 22). Water stored during those wet years supplemented the annual inflow to provide adequate water for irrigation in the first 9 years of reservoir operation $(1937-45)$. During the succeeding years of drought, however, the holdover storage in the reservoir ranged from 60,000 acre-feet in 1949 to less than 10,000 in 1947, and the irrigated areas in Texas were dependent chiefly upon the varying but generally small quantities flowing into the reservoir each year. As shown by Kister (Gatewood and others, 1963), the quality of water flowing into the reservoir fluctuates inversely with the quantity: the salt concentration is least during years of maximum inflow, such as 1941, and greatest during years of minimum inflow. The quality of the water released from the reservoir also is impaired by concentration of mineral salts in the reservoir because of evaporation, as indicated on figure 22.

\section{PECOS AREA}

The Pecos area (Hood and Knowles, 1952) is a plain 10 to 15 miles wide which extends from the Pecos River flood plain at Pecos and Barstow southward about 40 miles and almost to Balmorhea. Under this plain there are alluvial sediments, to depths exceeding 1,500 feet in places, which provided water to flowing wells as early as 1880. Beginning about 1910 large-capacity irrigation wells were developed outside the area of artesian flow. Static water levels in the pumped wells apparently declined about 20 feet during the early period of development, but there was little change from 1931 to 1947 . In the latter year 82 wells pumped 16,000 acre-feet of water to irrigate 5,800 acres.

Beginning in 1947 there was rapid development of ground water for irrigation; by 1950 there were 420 wells pumping 170,000 acre-feet for irrigation of more than 60,000 acres; and in 1955 about 750 wells pumped 350,000 acre-feet for irrigation of 85,000 acres. Several of these wells were on the Pecos River flood plain near Barstow and were used to supplement surface supplies; in that area pumping caused relatively little decline of water levels because there was recharge from the river. Southwest of the river, however, the 


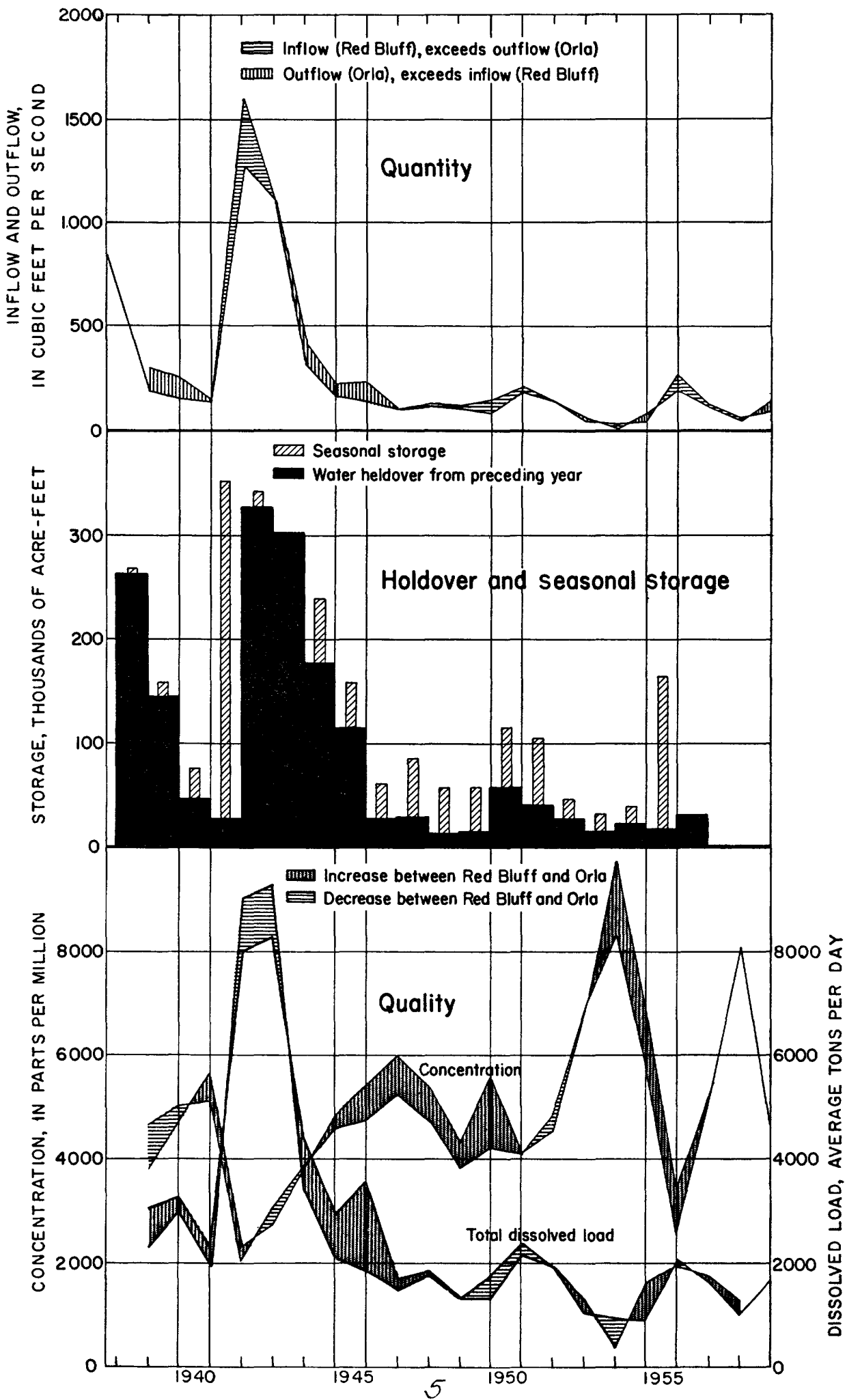

FIGURE 22.-Fluctuations of quantity and quality of water in Red Bluff Reservoir, 1937-58. In the years of least runoff during the drought, the dissolved solids in the inflowing water exceeded $8,000 \mathrm{ppm}$ (annual average) and the concentration was increased by evaporation in the reservotr. 
pumping by 1954 had created a cone of depression with a maximum depth of nearly 130 feet, about 5 miles west of Pecos. This decline, although it occurred during drought years, could be charged directly to the intensive new development beginning in 1947.

\section{BALMORHEA AND FORT STOCKTON}

The Edwards and associated limestones, which constitute major aquifers in the San Antonio area (Thomas and others, 1963a) and in the Devils River basin (p. D28), are also the source of numerous springs in the Pecos River basin. Some of the largest of these are the Phantom Lake, Giffin, and San Solomon Springs near Balmorhea, and the Comanche, Leon, and San Pedro Springs near Fort Stockton. As shown by the graphs of figure 23, the Phantom Lake Springs during most of the period of record have discharged at rates of 12 to $15 \mathrm{cfs}$, with considerably greater discharge for short periods apparently in response to exceptional recharge to the reservoir, or perhaps to storm flow past the gaging station. The discharge of Giffin Springs responds much more closely to variations in precipitation. Peak discharges were recorded at both springs following exceptional storms in September 1944, October 1945, and October 1951. Throughout the drought years 1952 to 1957 inclusive, the annual discharge of Phantom Lake Springs was less than in any of the 10 preceding years, and the discharge of Giffin Springs was also least during those dry years and in the dry years 1947 to 1949 .

The graph for Comanche Springs is similar to those for the springs near Balmorhea before 1947, in that it indicates a fairly uniform discharge, with seasonal fluctuations evidently in response to recharge from precipitation. However, the maximum monthly discharge dropped from $45.6 \mathrm{cfs}$ in February 1946 to $11.5 \mathrm{cfs}$ in February 1958, and the minimum monthly discharge declined from $42 \mathrm{cfs}$ in August 1946 to no flow in September 1955 and in extended periods in the summers of 1956-58. The record of San Pedro Springs beginning in 1947 shows a similar marked decline in discharge beginning in 1951. The declines are partly the result of drought beginning in 1947. However, the increased amplitude of seasonal fluctuations beginning in 1951, and the cessation of flow during the summers of 1955-58, are clearly caused by pumping from wells which tap the limestone ground-water reservoir and intercept the water that would be discharged at the springs under natural conditions.

\section{ALPINE AREA}

The Alpine area as described by Littleton and Audsley (1957) is small and sparsely populated, but in its semiarid climate and devotion to livestock it is typical of the broad trans-Pecos region (between the Pecos and Rio Grande) of west Texas. Northwest of Alpine there are several basins of interior drainage (Thomas and others, 1963b) with large ground-water reservoirs in alluvial or limestone aquifers. In contrast with these, the Alpine area is relatively high, drainage courses have been established to the Pecos, and its rocks are predominantly of volcanic origin and yield only meager amounts of ground water. Nevertheless, the Alpine area is similar to these interior basins in that its water resources are derived entirely from local precipitation, and nearly all the water from that precipitation is returned to the atmosphere within the area. Streams in the area are ephemeral, and contribute to the Pecos only after torrential storms. The economy of the area is dependent upon soil water from direct precipitation for its rangeland, and upon ground water for domestic and stock use and for municipal use by the town of Alpine.

The record of precipitation at Alpine shows the alternating wet and dry periods typical of the Great Plains meteorologic zone. The average annual rainfall was about $141 / 2$ inches in the 11 years $1930-40$, $181 / 2$ inches in the 10 years $1941-50$, and 11 inches in the 6 years 1951-56. These climatic fluctuations are reflected in the livestock industry: Brewster County's cattle were reduced from about 36,000 in 1950 to less than 19,000 in 1954, and sheep were reduced from about 210,000 to 87,000 in the same period.

As shown by Littleton and Audsley, ground water occurs chiefly in weathered volcanic rocks and alluvium which are only moderately permeable, so that most wells yield less than $10 \mathrm{gpm}$, and yields exceeding $100 \mathrm{gpm}$ are rare and unexpected. The city of Alpine, with a population greater than 5,000 in 1950, has been searching for water intermittently since 1923 and has drilled 34 wells, of which 6 were in use in 1956. In addition, more than 300 domestic wells have been completed within the city limits. As of 1955 the aggregate discharge from these wells was not meeting the peak summer demand estimated at $0.8 \mathrm{mgd}$.

There is evidence that both the storage in the ground-water reservoir tapped by the wells, and the natural discharge from that reservoir, have been reduced during the drought years. From 1948 to 1955 the water levels in 4 wells declined respectively 19 , 45,58 , and 62 feet, and in several other wells there were declines of 4 to 6 feet during the single year 1956. The natural discharge point for much of the ground water was Kohemot Springs, which in 1947 


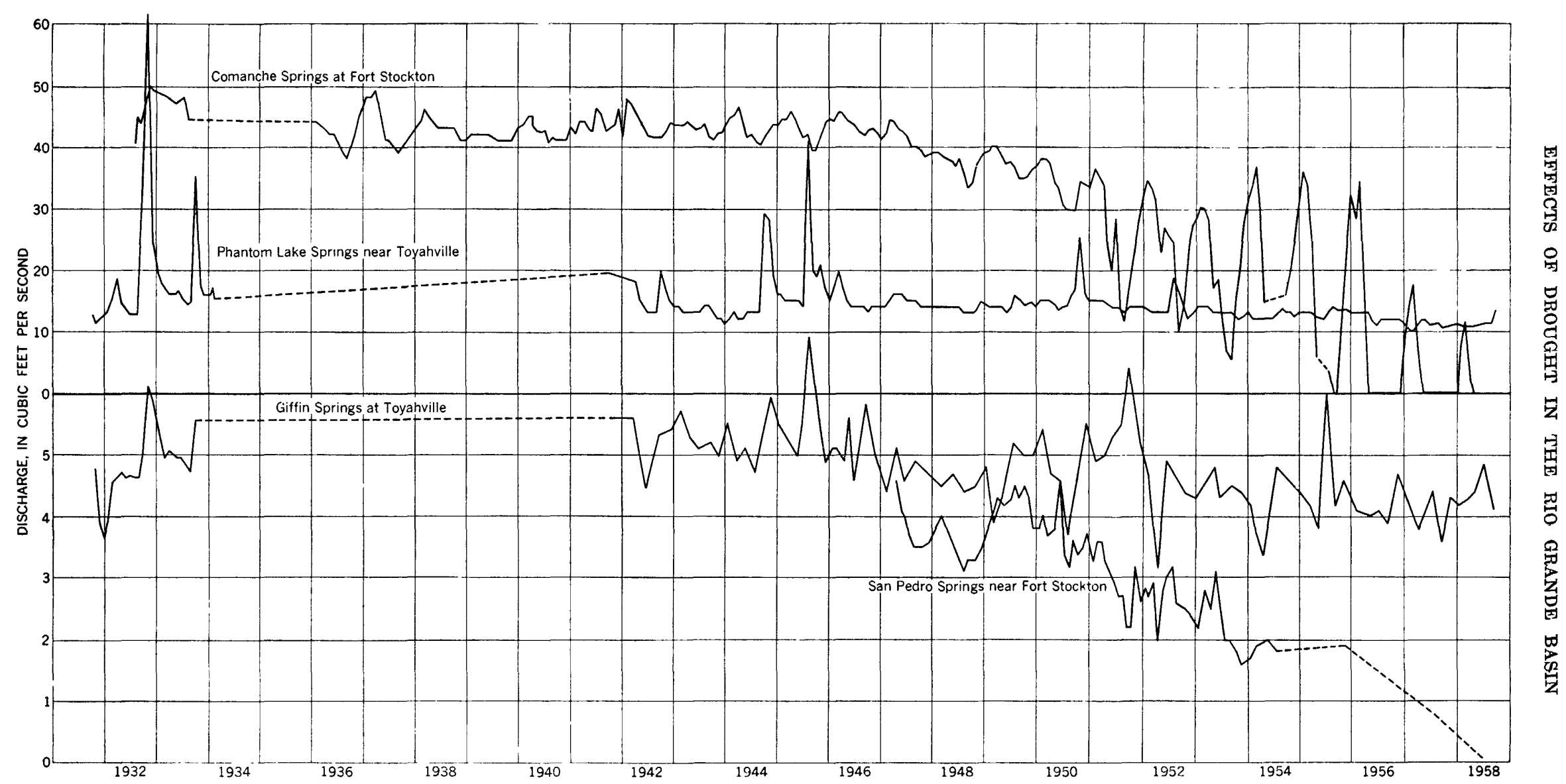

FIGURE 23.-Discharge of springs near Toyahville and Fort Stockton, Tex., 1931-58. The flow of springs near Toyahville diminished in 1947-49 and 1951-57 because of drought, but the marked decline and cessatic, of flow of springs near Fort Stockton was caused chiefly by pumptng from $\mathrm{w}^{\prime} \mathrm{lls}$ 
had an estimated discharge of $400 \mathrm{gpm}$ but in 1955 were dry. The data are too meager to show how much of this change was caused by increasing withdrawals from wells and how much was a natural effect of drought. Certainly the drought was a factor, for the ground-water reservoir is dependent upon the local precipitation for replenishment.

\section{REGULATION AND CONTROL DURING THE DROUGHT}

In this section "water shortage" refers to an inadequacy of usable water for developed requirements, whether because of insufficient quantity or inferior quality of the available supply. A brief resumé of the preceding sections indicates that drought has been a contributing factor in many of the water shortages observed or claimed during the drought years 1943-56, also that many of the shortages have been aggravated by developmental activities, and some have been created solely by those activities.

In the upper basin, where the area of use has remained relatively constant for many years, water shortages are experienced during years of drought and minimum streamflow because of the meager facilities for regulation. Water users who are able to divert a fairly constant amount of water in wet and dry years can avoid water shortages for themselves, although they aggravate the natural fluctuations in supply for users downstream. The users of water in the Roswell basin also have a local supply of water, which however is tributary to the Pecos River, so that they can affect the water supplies downstream although they are not affected by activities upstream. The natural outflow from the Roswell basin to the Pecos can be reduced by drought, but such a reduction can also result from pumping wells within the Roswell basin. Pumping can also induce encroachment of water of inferior quality into the ground-water reservoir.

The Carlsbad area depends primarily upon water brought in by the Pecos River, and its shortages may therefore result from development and use of water upstream in the drainage basin as well as from drought. Carlsbad also has a local ground-water supply which under natural conditions is tributary to the Pecos River and has been developed for municipal use and more recently for irrigation. Pumping here can reverse the direction of flow of the water so that the inferior river water contaminates the source of municipal supply. At Malaga Bend, downstream from Carlsbad, natural brines carrying a presumed constant quantity of salt $(140,000$ tons a year) are tributary to the river; the resulting deterioration in quality is of course greatest during periods of minimum flow of fresh water in the river, whether that minimum flow is occasioned by drought or by manmade depletions.

The Red Bluff Water Power Control District is dependent chiefly upon the water that flows into Red Bluff Reservoir, and both the quantity and quality of that water fluctuate in response to natural and artificial factors operating throughout the Pecos drainage basin upstream from Carlsbad. However, the users of water from springs near Balmorhea and Fort Stockton, and of water from wells southwest of Pecos, are among numerous people in the lower basin who derive their supplies from local sources and are not dependent upon the Pecos River.

The consumptive waste of water by saltcedar is credited with progressive reduction in the quantity of water available in the Pecos River basin. This plant is distributed widely and there has been progressively greater infestation along the Pecos River, as along the Rio Grande, for more than 40 years. The increasing consumptive waste by saltcedar, like the increasing consumptive use by crops, necessarily leaves less water available for downstream users. Hence, although the precipitation deficiency during the most recent drought may be no greater than during those recorded in earlier history, the deficiency in streamflow during the latest drought period would be greater.

Water shortages in the basin can be alleviated to some extent by conservation and development of water that is not now used beneficially, including the water consumed by phreatophytes, the water needed to dilute the brine inflow at Malaga Bend, and flood flows that escape from the basin. To the extent that the aggregate salvage by such means is insufficient to raise the available supply to equivalence with the developed demand, the alternative is to reduce the use of water to balance the supply. This involves allocation of water on the basis of water rights of the respective users, as defined in statutes and court decisions and interstate compacts. The following sections summarize briefly some of the problems of water rights in the Pecos River basin under the common law of Texas, the statutory law of New Mexico, and the interstate compact between the two States. Another section describes the physical efforts at conservation and fuller use of the supplies available during the drought.

\section{IANDOWNERSHP RIGHTS IN TEXAS}

By Texas statute no man shall ever be denied the right to drill a well on his property, and court decisions have repeatedly affirmed that "percolating" 
waters are the property of the landowner and may be used by him at his will, so long as the use is not wasteful. Under this doctrine, no one who actually develops and uses water from wells or springs, or streams that depend upon ground water, can have security in his investment or assurance of continued use of the water, unless he owns the land overlying the entire ground-water reservoir. This is shown in the recent decision concerning the water that discharged under natural conditions at Comanche Springs (Pecos County Water Control and Improvement District No. 1 v. Clayton W. Williams et al, 1954). The plaintiff, who supplied water to property that had used water from Comanche Springs for 90 years, was denied injunctive relief from the operations of landowners who by pumping from wells had reduced and at times stopped the flow from the springs (see hydrograph since 1947, fig. 23); and furthermore he can expect no protection against the effects of additional wells that may be drilled in the future. The court recognized that the verdict might have been different if plaintiff had introduced evidence to prove his claim that the waters supplying Comanche Springs flow in well-defined channels ("underground streams"). It is to be expected that the cavernous Edwards limestone in many places has water that should be included in the exclusive legal class of "definite underground streams," for the boundaries-the lawyers' "bed and banks" - can be determined by an expert hydrologist with an accuracy that would depend upon the effort expended. But no such evidence was introduced, and the waters feeding the spring were presumed to be "percolating."

In a State where the landowners have absolute right to the "percolating" waters beneath their lands, it is unnecessary and perhaps pointless to assess the relative degree to which droughts and human activity have been responsible for water shortages, because a water user may have no security in his supply in any event. The users of water from springs in various parts of Texas, as for example in the San Antonio area (Petitt, in Thomas and others, 1963a), can anticipate loss of their supply if the water can be diverted from its course by wells upgradient from the spring orifices. The users of the base flow of streams are similarly vulnerable to loss of their water, when wells pump from ground-water reservoirs that contribute to that base flow. And there is no likelihood of stemming the trend toward mining of water, in the Pecos area as well as in the Llano Estacado and in the Coastal Plain (Thomas and others, 1963a), as long as some of the owners of the overlying land wish to take the water.

\section{PECOS RIVER COMPACT}

The major purposes of the Pecos River Compact of 1948, entered into by the States of New Mexico and Texas, as stated in Article I of the Compact, are to provide for the equitable division and apportionment of the use of the waters of the Pecos River; to promote interstate comity; to remove causes of present and future controversies; to make secure and protect present development within the states; to facilitate the construction of works for, (a) the salvage of water, (b) the more efficient use of water, and (c) the protection of life and property from floods.

The basis of apportionment of the water between the two States is contained in the following paragraph from Article III of the compact:

(a) Except as stated in paragraph (f) of this Article, [which states that beneficial consumptive use of unappropriated fiood waters is to be apportioned fifty percent to Texas and fifty percent to New Mexico] New Mexico shall not deplete by man's activities the flow of the Pecos River at the New Mexico-Texas state line below an amount which will give to Texas a quantity of water equivalent to that avallable to Texas under the 1947 condition.

The report of the Engineering Advisory Committee explains why this particular basis for apportionment was selected:

A compact based on an allocation of water on a straightline percentage basis is not feasible or practical. The flow of water at any point in a given stream, under natural conditions, does not bear a straight-line relation to the infiow to the stream above that point. With a small inflow, the outfiow is a smaller percentage of the inflow than it is with a larger inflow. In the state of nature, the relationship between the inflow and outflow, instead of being a straightline one, is an exponential one. In a developed river basin the same is true. A compact in any basin, based on irrigated acreage, might be unfair to any or all parties to the compact. Depletion at a given point on a stream is not related in direct proportion to the irrigated area above that point. As irrigation in a basin increases, more and more of the water formerly lost by natural processes is converted to beneficial use. Conversely, if irrigated areas are abandoned, the accretion to the stream at some point below the abandoned area will not be equal to the amount of water that was being consumed by the area at the point of use. This again is due to natural losses. After the Pecos River Compact Commission by negotiation agrees on the particular condition which should be controlling as between the two States, that condition can be defined for purposes of administration by setting up in the compact schedules based upon relations between certain water-supply indexes and the state line fows. Since the fiow of the Pecos River is to a large degree controlled by reservoirs, it will not be necessary to provide in the compact for daily, monthly, or annual deliveries of water in accordance with the allocation of water as provided in a compact. A method of annual accounting which will permit credits and debits to accumulate within certain prescribed limits will be practicable. This will permit fiexible operation and the maximum use possible of the waters of the stream with existing facilities. If a credit and debit system is not established which will permit storage of water in upstream reservoirs in 
the maximum amount possible, within the prescribed limits, wastes of water from the basin at times will result from spill at the lowest reservoir, which in this case is the Red Bluff Reservoir.

The compact basis of apportionment requires a thorough analysis of the effects of man's development of water throughout the basin upon the water supply for Texas, in order to ascertain the depletion in New Mexico by "man's activities." Analysis of the effects of drought and other natural phenomena is important in the administration of the compact to the extent that they must be recognized and discriminated from the effects of man's activities with which the compact is concerned. Such an analysis is contained in the Report of the Engineering Advisory Committee, based on a series of river-operation studies under various assumed conditions for the period 1905-46 inclusive. The " 1947 condition" is the situation in the Pecos River basin as described and defined in that report, immediately prior to the final negotiation of the compact. The Engineering Advisory Committee, on the basis of its studies of records for the period 1905-46, concluded that the State-line discharge of the Pecos River, both base flow and flood flow, was less in 1947 than in 1905, chiefly because of the depletion of base flow by pumping in Roswell basin and the consumption of water by saltcedars.

The terms of the compact require that the depletion resulting from pumping in the Roswell basin and more recently in the Carlsbad area shall not exceed that of the "1947 condition." The compact thus depends upon New Mexico's statutory regulation of ground water to prevent further depletion of the base flow at the State line. The security and protection afforded by the compact to Pecos River water users in Texas could not be achieved if the entire drainage basin were within the State of Texas, and subject to the doctrine of absolute ownership of "percolating" ground water.

\section{APPROPRIATIVE RIGHTS IN NEW MEXICO}

According to the river-operation studies of the Engineering Advisory Committee to the Pecos River Compact Commission, if Alamogordo and Red Bluff Reservoirs had been in operation throughout the period 1905-46, the Carlsbad project would have been significantly short of water (10 to 40 percent less than demand) in only 6 of the 42 years, and Red Bluff Reservoir could have provided 160,000 acrefeet of water in all but 8 years. In 15 of the 46 years water would have spilled from Red Bluff without beneficial use in Texas, of which more than half (11/4 million acre-feet) would have spilled in the single year 1941; this is the extent of the unappropriated water in the basin above Girvin. Unless and until provision is made for storage and use of these infrequent flood flows the Pecos River supply may be considered fully appropriated for existing developments. Most of these appropriative rights date from 1905 or earlier.

The Engineering Advisory Committee also estimated that the dependable (mean) water supply for the Carlsbad project was 5,000 acre-feet less, and for Texas 15,000 acre-feet less, in 1947 than it would have been in 1905 with similar storage facilities. This reduction was attributed to reduction in base flow because of pumping in the Roswell basin, and to consumption of water by saltcedars. Aside from any need for control that may have arisen within the Roswell basin, therefore, such regulation has been required since 1947 , to prevent further depletion in the flow of the river "by man's activities" as specified in the compact.

The Roswell basin was the first of the major groundwater reservoirs to be subjected to regulation of development, and its history provides several lessons for administrators in other areas. Even after 50 years of development the Roswell basin still contains several million acre-feet of usable ground water in storage, but the amount that can be counted upon for use perennially can be no greater than the average annual recharge. This is true of ground-water reservoirs throughout the Southwest, but the Roswell basin was more favorably situated than most for regulation on a perennial-yield basis. The ground-water law that established the basis for regulation was passed when the reservoir was in essential equilibrium, although the water users had been fearful of overdevelopment for many years prior to enactment of the statute. At the time regulatory measures were first undertaken, an estimate of average annual recharge was available, and this estimate has been confirmed in recent years. Without a reliable estimate of the average annual recharge, there is necessarily uncertainty whether the depletion of storage during dry years can be made up by recharge in subsequent years.

Many new wells drilled since 1931 obtain water entirely within the law because they were beyond the boundaries of regulated portions of the reservoir at the time of drilling. The area declared in 1931 included chiefly the area in which irrigation wells were obtaining supplies from the San Andres limestone, and embraced about 770 square miles. This original area was extended in 1940, and further extended in 1941, 1942, 1946, 1948, 1950, 1953, and 1954, so that the declared area for the artesian aquifer now embraces more than 3,600 square miles. Each extension was made necessary by the drilling of new 
wells outside the limits of the previously declared areas, and thus followed the development of additional rights to water in the common reservoir. The irrigated acreage increased from 55,000 acres in 1931 to 95,000 in 1945 to 125,000 acres in 1955 .

Fiedler and Nye (1933) pointed out that additional ground-water supplies could be developed from the shallow alluvial aquifer, which was replenished not only by natural means but also by downward percolaiion of water taken from the artesian aquifer or from the river and used for irrigation. From the standpoint of the Roswell basin alone, and of the ground water that is the dominant phase of the hydrologic cycle in that basin, this was a sound development of additional water. Wells pumped less than 20,000 acre-feet annually from the shallow aquifer prior to 1935 , but the pumpage probably exceeded 75,000 acrefeet in 1937 when the shallow aquifer was declared. In this development, the Roswell basin was not considered in its relation to the larger Pecos River basin of which it is a part. The contribution to the Pecos River from the Roswell basin in the years 1938-40 and $1946-57$ was about 22,000 acre-feet per year less than it had been prior to 1935 , according to estimates prepared for the Engineering Advisory Committee to the Pecos River Compact Commission (Flook, 1958).

Complicating the problem is our uncertainty, even after 30 years of data collection, as to the yield that can be sustained from the Roswell basin for irrigation by wells plus contribution to the Pecos River. The pumping that has depleted storage at rates approaching 100,000 acre-feet in some years would constitute good reservoir management provided the water could be replaced in future years when the supply is greater and the demand less. Inasmuch as precipitation can meet a large proportion of crop needs in wetter years, a constant rate of annual withdrawal by pumping would be less economical than would heavy pumping during drought and light pumping in the wetter years. Such variations in draft are possible because of the large reserve in storage. Existing records (fig. 18) indicate that reservoir storage in 1952 was not much less than in 1940, and that therefore the wet years 1941 and 1942 provided enough water to carry through the first several years of drought. The depletion in subsequent years, however, cannot be made up unless the future includes years wet enough to permit a drastic reduction in annual pumpage. And certainly a part of the increased use of water within the Roswell basin during the drought has been at the expense of users of the Pecos River downstream.
Pumping in the Carlsbad area was probably insufficient to have a significant effect upon Pecos River flow during the period $(1905-46)$ considered by the Engineering Advisory Committee to the Pecos River Compact Commission. Since 1947, however, pumping has reduced the inflow to the river at Carlsbad Springs, increased the seepage from the river and from distribution canals, and created storage space which will doubtless be filled at least in part in future years of more abundant supply. All these effects tend to reduce the amount of water available downstream. To the extent that the pumped water was used on lands of long-established water rights, in lieu of failing stream supplies during drought, the wells constitute a development of additional storage facilities along the river-facilities which in some future year may, like a surface reservoir, capture and store flood waters that would otherwise continue downstream unused. To the extent that the pumped water was put to new uses, however, it may cause a persistent reduction in the supplies available downstream.

\section{CONSERVATION AND SALVAGE OF WATER}

In 1940, according to the report of the Pecos River Joint Investigation (National Resources Planning Board, 1942, p. 18, 117-137) the Pecos River basin above Girvin had 210,000 acres of irrigated land, which consumed an estimated 570,000 acre-feet of water. There were also about 450,000 acres of native vegetation and 100,000 acres of miscellaneous land where the total consumptive water requirements exceeded 1,100,000 acre-feet, including precipitation. It was concluded that, in a year of average runoff, the streamflow depletion to meet these requirements would be about 840,000 acre-feet, or 93 percent of the total production of runoff above Girvin. Of the total streamflow depletion, " 42 percent is accounted for by the irrigated areas and 33 percent by the areas of native vegetation. In other words, there is a nonbeneficial depletion of water supply by native vegetation incidental to irrigation amounting to more than three-fourths of the depletion by the irrigated lands, and this native vegetation takes an average annual toll from the basin's water supply of 273,000 acrefeet."

From this statement it is clear that, although there is very little unappropriated water in the basin, a large proportion of the total production is not used beneficially. The Pecos River Compact in recognition of this situation includes paragraphs defining and apportioning "water salvaged," and commits both States to support legislation for projects to eliminate nonbeneficial use of water. 


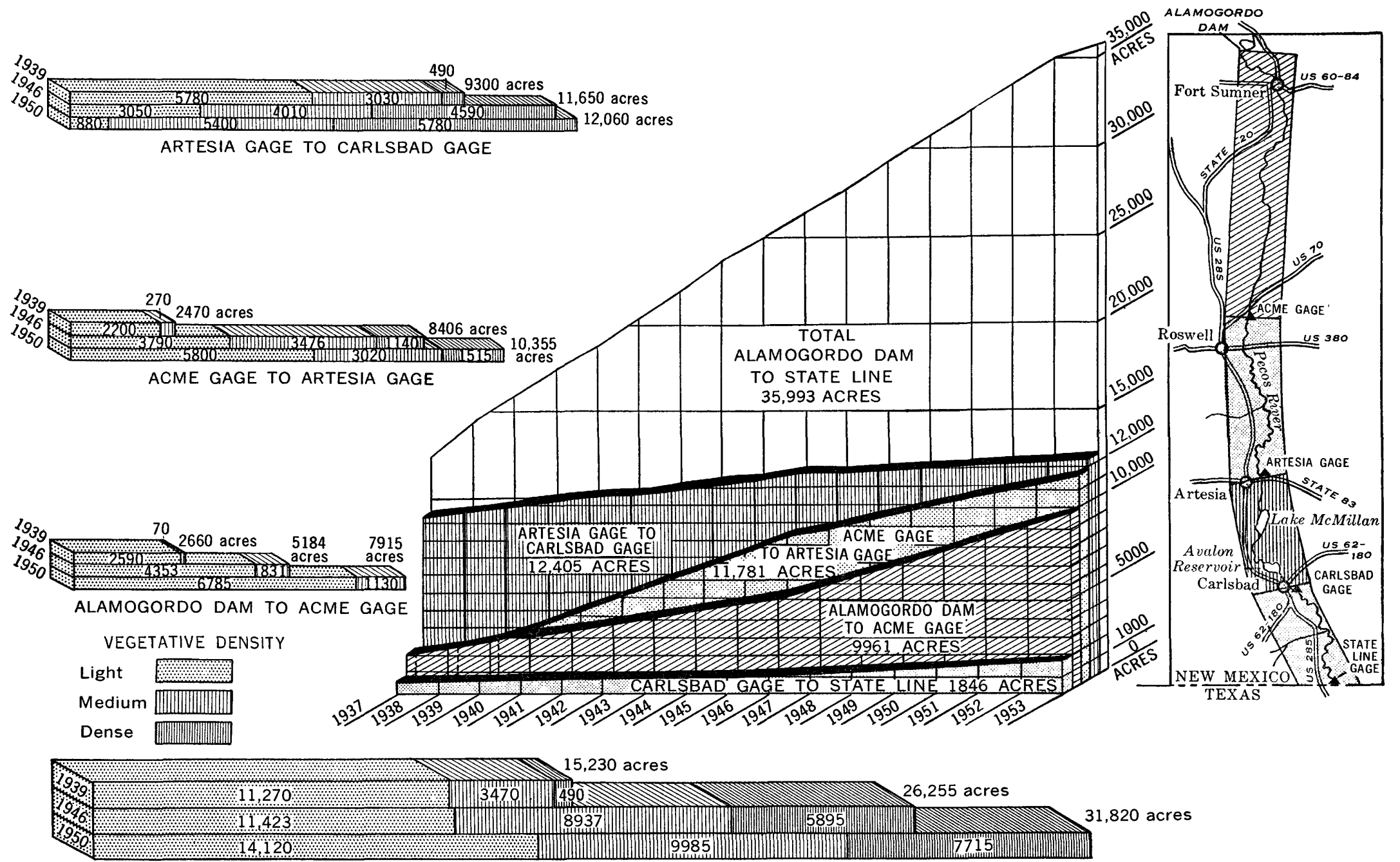

TOTAL GROSS AREA AND DENSITY OF SALTCEDAR, IN ACRES, FROM ALAMOGORDO DAM TO STATE LINE

Frodre 24.-Increase in saltcedar area, Pecos River basin in New Mexico, 1937-53. (Pecos River Comm., 1955, exhibit 4.) 
Saltcedar is a waster, or nonbeneficial consumptive user, of water, and it is of especial concern in the Pecos River basin because of its prolific nature, drought resistance, and extravagant water use. As shown in figure 24 , it covered about 15,000 acres in 1939 at the time of Pecos River Joint Investigation, and the acreage had increased to 25,000 in 1946 and to 36,000 in 1953. About one-third of that acreage was on the delta formed by the river in Lake McMillan, and this area has received special study, as summarized in a report of the Pecos River Commission (1955) which estimates the stream depletion in the Lake McMillan area to be about 40,000 acre-feet a year, most of which could be salvaged by eradicating or bypassing the saltcedars. Throughout the Pecos basin the infested area has continued to increase in recent years, reaching an estimated 60,000 acres in 1960.

The inflow to the river of brine at Malaga Bend is the basis of another proposed conservation program. According to Hale, Hughes, and Cox, (1954)-

The source of the concentrated brine in the alluvium at Malaga Bend is a brine aquifer that underlies the area at a depth of about 200 feet $* * *$. The most feasible method of preventing the brine from entering the river appears to be by pumping the brine at such a rate as to maintain the head of the brine below river level ***. The most favorable nearby surface-disposal area appears to be the Queen Lake depression about 2 miles southwest of the Malaga Bend ***. Although an action program which involves pumping of brine from the basal brine aquifer in the Malaga Bend area and storage of the brine in Queen Lake appears to have a fair chance of success hydraulically, such a program should be considered as experimental.

Elimination of the brine from the river would make no more water available for Texas, of course, but it would improve the quality of the water considerably, and thus permit increased irrigation with the same supplies.

\section{REFERENCES CITED}

Bjorklund, L. J., and Motts, W. S., 1959, Geology and water resources of the Carlsbad area, Eddy County, New Mexico: New Mexico State Engineer open-file rept., 322 p. plus A1-132, 45 figs.

Chang, C. W., 1957, Soil salinity problems along the Rio Grande in New Mexico and Texas, in Problems of the Upper Rio Grande, an arid zone river: U.S. Comm. for Arid Resource Improvement and Development, Pub. 1, p. 49-54.

Conover, C. S., 1954, Ground-water conditions in the Rincon and Mesilla Valleys and adjacent areas in New Mexico: U.S. Geol. Survey Water-Supply Paper 1230, 195 p.

Conover, C. S., 1956, Groundwater-Its importance to State: New Mexico Prof. Engineer, v. 8, no. 7, p. 11-13.

Darton, N. H., 1933, Guidebook of the Western United States, pt. F, Southern Pacific Lines, New Orleans to Los Angeles: U.S. Geol. Survey Bull. 845, p. 74-87.
Duisberg, P. C., 1957, Post symposium developments and the job ahead, in Problems of the Upper Rio Grande, an arid zone river: U.S. Comm. for Arid Resource Improvement and Development, Pub. 1, p. 63-69.

Fiedler, A. G., and Nye, S. S., 1933, Geology and groundwater resources of Roswell artesian basin, New Mexico: U.S. Geol. Survey Water-Supply Paper 639, 367 p.

Flook, L. R., 1958, Memorandum on Pecos River base flows and their relation to precipitation: Denver, Tipton and Kalmbach, 18 p.

Follett, W. W., 1898, Rio Grande waters: U.S. 55th Cong., $2 d$ sess., Senate Doc. No. 229, 287 p., 10 maps.

Gatewood, J. S., Wilson, Alfonso, Thomas, H. E., and Kister, Lester, 1963, General effects of drought upon water resources: U.S. Geol. Survey Prof. Paper 372-B. (In press.)

Gordon, E. D., 1962, Geology and ground-water resources of the Grants-Bluewater area, Valencia County, New Mexico, with sections on aquifer characteristics, by $H$. $O$. Reeder, and chemical quality of the ground water, by J. L. Kinkler, U.S. Geological Survey: New Mexico State Engineer Tech. Rept. 20. (In press.)

Hale, W. E., Hughes, L. S., and Cox, E. R., 1954, Possible improvement of quality of water of the Pecos River by diversion of brine at Malaga Bend, Eddy County, New Mexico: Pecos River Commission, New Mexico and Texas, 43 p., 8 pls., 5 figs.

Hantush, Mahdi S., 1955, Preliminary quantitative study of the Roswell ground-water reservoir, New Mexico: New Mexico Institute Mining and Technology, Socorro, $196 \mathrm{p}$.

Hills, J. M., 1942, Rhythm of Permian seas-a paleogeographic study: Am. Assoc. Petroleum Geologists Bull., v. 26, p. 217-255.

Hood, J. W., and Knowles, D. B., 1952, Summary of groundwater development in the Pecos area, Reeves and Ward Counties, Texas: Texas Board Water Engineers Bull. $5202,11 \mathrm{p}$.

International Boundary and Water Commission, United States and Mexico, 1931-58, Flow of the Rio Grande and tributary contributions: Water Bulls. 1-28, incl., published annually.

King, P. B., 1942, Permian of west Texas and southeastern New Mexico: Am. Assoc. Petroleum Geologists Bull., v. 26, p. 535-763.

Lang, W. B., 1937, The Permian formations of the Pecos Valley of New Mexico and Texas: Am. Assoc. Petroleum Geologists Bull., v. 21, p. 833-898.

Littleton, R. T., and Audsley, G. L., 1957, Ground-water geology of the Alpine area, Brewster, Jeff Davis, and Presidio Counties, Texas: Texas Board Water Engineers Bull. 5712, $87 \mathrm{p}$.

Lyerly, P. J., 1957, Salinity problems in the El Paso area, in Problems of the Upper Rio Grande, an arid zone river: U.S. Comm. for Arid Resource Improvement and Development, Pub. 1, p. 55-62.

Morgan, A. M., 1938, Geology and shallow water resources of the Roswell artesian basin, New Mexico: New Mexico State Engineer 12th-13th Bienn. Repts. (1934-38), Santa Fe, p. 155-249.

National Resources Committee, 1938, Regional planning, pt. VI of Rio Grande joint investigation in the Upper Rio Grande basin in 1936-37; 2 v., 566 p., 22 maps. 


\section{D58}

DROUGHT IN THE SOUTHWEST, 1942-56

National Resources Planning Board, 1942, Regional Planning, pt. 10 of Pecos River joint investigation in the Pecos River basin in New Mexico and Texas; 202 p., 1 map.

Pecos County Water Control and Improvement District no. 1 v. Clayton W. Williams et al, 1954, Tex. Civ. App., 271 SW (2d) 503.

Pecos River Commission, 1955, Water salvage and salinity alleviation action programs: duplicated rept., 18 p., 10 exhibits and 3 appendixes.

Powell, W. J., 1958, Ground-water resources of the San Luis Valley, Colorado: U.S. Geol. Survey Water-Supply Paper 1379, 282 p.

Reynolds, S. E., 1958, Rio Grande underground water basin: New Mexico State Engineer 23d Bienn. Rept. (1956-58), Santa Fe, p. 15-28.

Riggs, H. C., 1953, A method of forecasting low flow of streams: Am. Geophys. Union Trans., v. 34, p. 427-434.

Roberts, J. R., and Nash, J. P., 1918, Geolgoy of Val Verde County: Texas Univ. Bull. 1803, 51 p.

Robinson, T. W., 1957, Phreatophytes: U.S. Geol. Survey Water-Supply Paper 1423, 82 p.

Smith, R. E., 1956, Ground-water resources of the El Paso district, Texas: Texas Board Water Engineers Bull. $5603,33 \mathrm{p}$.

Spiegel, Zane, and Baldwin, Brewster, 1962, Geology and water resources of the Santa Fe area, New Mexico: U.S. Geol. Survey Water-Supply Paper 1525. (In press.)

Thomas, H. E., 1962, The meteorologic phenomenon of drought: U.S. Geol. Survey Prof. Paper 372, 43 p. (In press.)
Thomas, H. E., and others, 1963, Effects of drought in central and south Texas: U.S. Geol. Survey Prof. Paper 372. (In press.)

- 1963b, Effects of drought in basins of interior drainage: U.S. Geol. Survey Prof. Paper 372-E. (In press.)

Troxell, H. C., 1953, The influence of ground-water storage on the runoff in the San Bernardino and eastern San Gabriel Mountains of southern California: Am. Geophys. Union Trans., v. 34, p. 552-562.

U.S. Bureau of Reclamation, 1956, Reconnaissance report on Closed Basin Division, San Luis Valley Project, Colorado : Region 5, dupl. rept., $52 \mathrm{p}$.

U.S. Congress, 1949, Pecos River Compact: U.S. 81st Cong., 1st sess., Senate Doc. 109, Public Law 91.

U.S. Geological Survey, 1932, Geologic map of the United States : $1: 2,500,000$.

U.S. Salinity Laboratory Staff, 1954, Diagnosis and improvement of saline and alkaline soils: U.S. Dept. Agriculture Handb. 60, p. 69-82.

Wilcox, L. V., 1957, Analysis of salt balance and salt-burden data on the Rio Grande, in Problems of the Upper Rio Grande, an arid zone river: U.S. Comm. for Arid Resource Improvement and Development, Pub. 1, p. 37-44.

Winograd, I. J., 1959, Ground-water conditions and geology of Sunshine Valley and western Taos County, New Mexico: New Mexico State Engineer Tech. Rept. 12, 70 p.

Witmer, T. R., 1956, Compacts, treaties, and adjudications: U.S. Dept. Interior, Documents on the use and control of the waters of interstate and international streams, $732 \mathrm{p}$. 


\section{INDEX}

Page

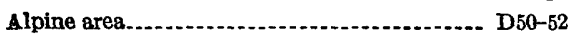

Altitude, relation to precipitation............... 10

Appropriate rights, New Mexico............... 54-55

Artesian wells, San Luis Valley................. 6 Roswell, N. Mex.

Balmorhea, Tex., springs near.................... 50 Bjorklund, L. J., Carlsbad area................. 43-48 Bluewater Lake . Brines, at Malaga Bend. ........................ 52,57

Caballo Reservoir.

Capitan limestone............................ 45, 47

Carlsbad area, by L. J. Bjorklund............. 43-48 effects of pumplng

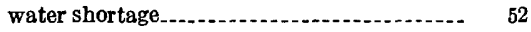

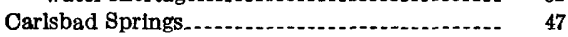

Chalk Bluff formation.......................... 40-41

Comanche series............................ 27

Comanche Springs............................ 50,51

Canover, O. S., Ground-water reservoirs........ 14-16

C. S., quoted............................. 9,15,19

Conservation of water

Consumptive waste. .......................... 19-20, 23

Darton, N. H., quoted.

Devils River, precipitation-runoff relation...... 28-32

Del Rio, Tex., water level in well near........... 28

Drought, regulation and control during.......- 52

Duisberg, P. C., quoted....................... 23

Eagle Ford formation............................. 27

Edwards and assoclated limestones.............. $\quad 50$

Edwards Plateau, geology ground-water reservoirs...................... 32-33

ground-water storage and discharge.......... 27-28

quality of water.

Elephant Butte-Fort Quitman area, descrip-

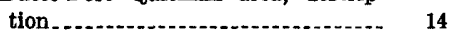
inflow and outflow ........... 4,5 Elephant Butte Reservotr............. 4, 5, 14, 15, 18, 20

El Paso Valley, effects of drought................ 22 ground-water reservoirs....................... 16

water storage.

Embargo of 1896.............................. 3,16

Evapotranspiration, effect on drought. See Phreatophytes.

Extent of area

Floods, Devils River

Flow, in and out of basin.

Fort Quitman, dissolved load in river at-ro.

Fort Stockton, Tex., springs near

Giffin Springs. .

Goodenougn Springs

Gordon, E. D., Grants-Bluewater area........... 12-14

Grants-Bluewater area, by E. D. Gordon....... 12-14

Ground-water development, Grants-Bluewater area.

San Luis Valley
Ground-water reservoirs [Elephant ButteFort Quitman area], by C. $\mathrm{S}$. Conover........................... D14-16

Hale, W. E., Hughes, L. S., and Cox, E. R., quoted.

Irrigation, Carlsbad area early _................ 3

Pecos River basin

San Luis Valley........................... 6-7

Sunshine Valley........................ $\quad 0,10$

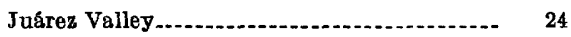

Kohemot Springs............... 50-52

Lake A valon ............................. 43, 45, 47

Landownership rights, Tex................... 52-53

Lang, W. B., quoted. 36

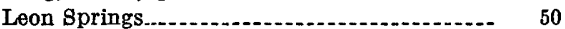

Location of area . .

Lower Rio Grande basin, quality of water.... 33-35 volume of streamflow ................. 25-27

water resources............................. 25-57

McLaughlin, T. G., San Luis Valley, Colo_.. 6-7

Malaga Bend, natural brines at .......... 52, 57

Mesilla Valley, ground-water reservoirs....... 14-16 water storage............................ 18-19

Middle Valley, N. Mex., description........ 7 inflow and outflow...................... 4,5 water resources......................... 7-8

Municipal water supply, Carlsbad, N. Mex... $\quad 45$ Grants-Bluewater area...................... 12 Santa Fe, N. Mex......................... 10,11

National Resources Committee, quoted .....-.- 7-9 National Resources Planning Board, quoted.... 36-37,

Pecos area, water resources........................ 48-50

Pecos River, conservation and salvage of water $-55-57$ description.

dissolved load

geologic history

lower basin, Texas........................... 48-52

regulation and control during drought...... 52-55 upper and middle basins, New Mexico...... 36-48

Pecos River Compact of 1948, quoted.......... 53-54

Phantom Springs................................. 50,51

Phreatophytes, effect on water supply ......... $\quad 20$

Phreatophytes. See also Saltcedar.

Precipitation, Alpine area .................. 50

Precipitation, Carlsbad, N. Mex............. 45,47

Precipitation, Del Rio, Tex....................... 31

Precipitation, Devils River...................... 30-32

Precipitation, Grants-Bluewater area............ 12, 13

Precipitation, Pecos River basin.............. 39

Pueblo colonization grants.

Quality of water, lower Rio Grande............ 33-35 upper Rio Grande
Page

Red Bluff Reservoir........................ D48, 49,54 Red Bluff Water Power Control District.... 48, 49, 52 Reservoirs, ground-water, Carlsbad area..... 43, 45, 46 Devils River.................................. 32-33 Edwards Plateau. Elephant Butte-Fort Quitman area.......... 14-16 El Paso Valley Middle Valley, N. Mex......... 7 Roswell basin............................. 40-43, 44 Reservoirs, surface 18 Río Conchos, dissolved load..................... 33-34 Rio Grande, Colorado, and Tijuana Treaty of 1944 Rio Grande Compact of 1938............. 3, 23-25 Rio Grande Compact of 1938, quoted.......... 25

Rio Grande Joint Investigation. See National Resources Committee.

Rincon Valley, ground-water reservoirs........ 14-16 water storage ................................. 18-19

Roswell basin, effects of depletion of groundwater storage......................... 43, 44 history of ground-water development ....... $37-40$ water resources.

Runoff, Devils River............................... 28-32 Edwards Plateau.......................... 27, 28 lower Rio Grande.......................... 25-26 Santa Fe area . . .

Saltcedar, effect on water supply......... 20,52,56,57 Salvage of water $\ldots \ldots$ San Acacia, salt concentration of water at.....- 20 San Andres limestone........................... 40-41

San Luis Valley, Colo., by T. G. McLaughlin.. 6-7 description of..................... 6 inflow and outflow unconfined aquifer......................... 6, 17-18 water salvage San Marcial, salt concentration of water........ 20-22 San Pedro Springs............................... 50,51 San Solomon Springs........ 50 Santa $\mathrm{Fe}$ area, description.......................... 10

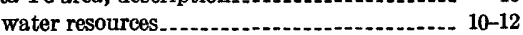
Spiegel, Zane, quoted........................... 12 Sunshine Valley, by I. J. Winograd ............ $0-10$ description.

Toyahville, Tex., springs near.-.

Upper Presidio, dissolved load in river at.-...-- 33-35 Upper Rio Grande basin, facilities for water

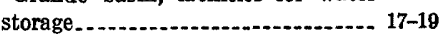
history of water shortages................ 3 salinity of water water resources.................................. 3-25 volume of streamflow..................... 4-5 Uranium

Waste, comsumptive.............................. 19-20 Water shortage, upper Rio Grande, history....- 3 Winograd, I. J., Sunshine Valley............. $\quad 0-10$

Yeso formation $40-41$ 